\title{
Nové možnosti prístupu k výskumu dejín vojvodstva v 11. storočí
}

\author{
Dániel Bagi \\ Katedra dejín východnej a strednej Európy, \\ Inštitút histórie, Filozofická fakulta, Univerzita Loránda Eötvösa, \\ Budapešt'
}

New possibilities of approach to research the history of the duchy in the $11^{\text {th }}$ century

Abstract: The study presents previous research on the history of the duchy in Hungarian, Czechoslovak (Czech) and Polish historiography as well. It also represents a new research concept. The Arpads' system of power division in the $11^{\text {th }}$ century cannot be considered either as a model of state development or as a mere exercise of dynastic inheritance or family law. Instead of research on the state development, it is more appropriate to proceed from the then understanding of law and the organization of society, contained primarily in narrative sources and then situate the history of the duchy into it. The basis of this order had been represented by the system of relations between free people, based on a friendship confirmed by an oath. We can assume that these interpersonal relations had also determined the competence of the duchy and dukes. When comparing the Arpad dynasty duchy with similar constitutions of the Piast and Přemyslid dynasties, we can state that the territorial power division does not necessarily correspond to the authority/competent one. We still do not know the exact territorial extent of the duchy in the Kingdom of Hungary. However, we can say with certainty that its centers, unlike the Piast ones, had only slightly affected the main royal residences. While good relations had been lasting in the ruling dynasty, the dukes had important competencies. These competencies meant a share in the royal power, so the agreement had primarily represented the division of competencies. This might explain why kings and dukes regularly appear together in the main positions of the country, together representing the ruling power. The model of the power division between the Arpads in the $11^{\text {th }}$ century was thus primarily family-based. It was based on consensus among family members. According to this consensus, the power division affecting the whole country had been in the ratio $2: 1$. The sources do not mention exactly what the members of the ruling family had divided among themselves. We can suppose that the reason was because it was not necessary, since the Hungarian chronicler understood the term divisio regni in the meaning of the disputes over the throne, as well as the power division. 


\section{Dániel Bagi}

Keywords: royal duchy, the Árpád dynasty, the Kingdom of Hungary, power division.

DOI: https://doi.org/10.24040/ahn.2021.24.02.05-60

I.

Král'ovské vojvodstvo, podl'a zaužívaného pomenovania v mad'arskej medievistike dukátus, ktoré vzniklo v priebehu 11. storočia a bolo zrušené v dobe Kolomana Učeného (1095 - 1116), odjakživa vzbudzovaloživý záujem mad'arskej historiografie. Jedna jej vetva naň vždy nazerala z hl'adiska rozvoja štátu, respektíve pôvodu uhorského štátu, avšak druhá ho výlučne považovala za vnútrodynastickú záležitost' a $\mathrm{v}$ prvom rade ho skúmala $\mathrm{z}$ hl'adiska nástupníckeho práva, prípadne bojov o trón.

V historiografickej línii, chápajúcej vojvodstvo ako model rozvoja štátu, György Györffy, skúmajúc pôvod uhorského štátu, sa prvýkrát detailne zaoberal okruhom otázok ohl'adom vojvodstva. ${ }^{1}$ Györffy, opierajúc sa o text ${ }^{2}$ jedného zo zákonov Kolomana Učeného, opísal vojvodstvo ako dva navzájom sa prelínajúce útvary. Na jednej strane to bol jeden územný celok a na druhej strane od neho nezávislé, na území celej krajiny roztrúsené majetkové zoskupenie. ${ }^{3}$ Prvé z nich považoval Györffy za archaickú štruktúru. Jeho úpadkom okolo roku 1115 však modernejšie majetkové zoskupenie nezaniklo. ${ }^{4}$ Podobne ako vo svojej teórii o pôvode komitátov, odvodil pôvod oboch predpokladaných štruktúr, teda územného a majetkového zoskupenia, z uhorských pomerov 10. storočia. ${ }^{5}$ Územie vojvodstva odvodzoval od hlavných osídlených oblastí podmanených a k mad'arským kmeňom pripojených etník. Počiatok vojvodstva ako územnej jednotky považoval za časovo zhodný s dobou zaujatia vlasti (honfoglalás). Týmto sa Györffy postavil

\footnotetext{
${ }^{1}$ GYÖRFFY, György: A magyar nemzetségtől a vármegyéig, a törzstől az országig. In: Századok, roč. 92, 1958, s. 12-87, 565-615; GYÖRFFY, György: István király és múve. Budapest : Gondolat, 1977, s. 374-376.

2 Ducis ministri, qui in mega regis sunt, et regis, qui in mega sunt ducis, ante comitem et iudicem, minores vero ante iudicem delitigent. ZÁVODSZKY, Levente (ed.): A Szent István, Szent László és Kálmán korabeli törvények és zsinati határozatok forrásai. Budapest : Szent-István-Társulat, 1904, s. 187.

${ }^{3}$ GYÖRFFY, Gy.: A magyar nemzetségtől a vármegyéig, s. 48.

${ }^{4}$ GYÖRFFY, Gy.: A magyar nemzetségtől a vármegyéig, s. 48-49.

${ }^{5}$ GYÖRFFY, Gy.: A magyar nemzetségtől a vármegyéig, s. 29. V dukátuse predtým videli zriadenie mad’arského pôvodu Henrik Marczali a István Rugonfalvi Kiss, pozri MARCZALI, Henrik: Magyarország története az Árpádok korában (1038 - 1301). In: A magyar nemzet története II. Szerk. Szilágyi Sándor, Budapest : Athenaeum, 1896, s. 59-60; RUGONFALVI KISS, István: Trónbetöltés és ducatus az Ârpád-korban. In: Századok. roč. 62, 1928, s. 749.
} 
proti skoršie formulovaným hypotézam $\mathrm{v}$ mad'arskej historiografii, ktoré považovali král'ovské vojvodstvo za pôvodom slovanské6 (ruské, české alebo pol'ské), prípadne germánske. ${ }^{7}$

Podl'a Györffyho stanoviska funkciou král'ovského vojvodstva bola obrana hraníc. Tu sa koncentrovala približne jedna tretina vojenských a hospodárskych zdrojov krajiny. ${ }^{8}$ Podl'a Györffyho pozostávalo král'ovské vojvodstvo z troch väčších územných celkov. Strediskom jedného z nich bola Nitra, druhý zaberal Biharsko, Sabolčský komitát a Nyírség a tretí vznikol okolo hradu Krašov v južnej časti Uhorska. ${ }^{9}$ Posledný menovaný - podl'a neho - taktiež posilňuje charakter vojvodstva v oblasti obrany hraníc, ked’že dobre poslúžil vo vojne proti Byzancii v roku 1071.10 Vojvodstvo okrem toho zahŕňalo územia viacerých komitátov, ako Nitra, Hont, Zemplín, Novohrad, Uh, Boržava, Békeš, Zaránd, Krašov, Sriem. ${ }^{11}$

V sedemdesiatych rokoch minulého storočia prišiel Gyula Kristó s novým náhl'adom, ktorý protirečil Györffyho predstavám. Podl'a neho král’ovské vojvodstvo 11 . storočia nepozostávalo z dvoch základných štruktúr, ale predstavovalo jednu územnú jednotku. ${ }^{12}$ Okrem toho vznik vojvodstva nie je podl'a neho možné odvodzovat' z doby zaujatia vlasti, teda nie je rovnako staré ako zrod uhorskej štátnej organizácie, ale vzniklo až $\mathrm{v}$ štyridsiatych rokoch 11 . storočia a ako územno-mocenská jednotka zaniklo v časoch Kolomana. ${ }^{13}$ Kým Györffy videl vo vojvodstve hraničnoobranné územie, Gyula Kristó ho považoval za periférne, takmer neobývané pohraničné časti král'ovstva Arpádovcov. Na týchto územiach sa,

\footnotetext{
${ }^{6}$ PAULER, Gyula: A magyar nemzet története az árpádházi királyok alatt I - II. Budapest : Athenaeum, 1899, s. 96-97; ACSÁDY, Ignác: A magyar jobbágyság története I. Budapest : Grill Károly Könyvkiadóvállalata, 1908, s. 125; ŠUFFLAY, Milán: Szláv párhuzamok a „Rex junior" czíméhez. In: Századok. roč. 43, 1909, s. 500; DOMANOVSZKY, Sándor: Az Árpádok trónöröklési jogához. In: Századok. roč. 63, 1929, s. 37-52; HÓMAN, Bálint: Magyar pénztörténet 1000 - 1325. Budapest : Magyar Tudományos Akadémia, 1916, s. 217; KARÁCSONYI, János: A magyar nemzet áttérése a nyugati kereszténységre 997 - 1095. Oradea - Nagyvárad : Szent László-Nyomda, 1926, s. 104; HÓMAN, Bálint - SZEKFÛ́, Gyula: Magyar történet I. Budapest : Királyi Magyar Egyetemi Nyomda, 1939, s. 258.

7 MÁLYUSZ, Elemér: A patrimoniális királyság. In: Társadalomtudomány. roč. 13, 1933, s. 37-49; DEÉR, József: Pogány magyarság, keresztény magyarság. Budapest : Holnap Kiadó, 1993, s. 126-127.

${ }^{8}$ GYÖRFFY, Gy.: A magyar nemzetségtől a vármegyéig, s. 29.

${ }^{9}$ GYÖRFFY, Gy.: A magyar nemzetségtől a vármegyéig, s. 50-51.

10 GYÖRFFY, Gy.: A magyar nemzetségtől a vármegyéig, s. 50-51.

${ }^{11}$ GYÖRFFY, Gy:: A magyar nemzetségtől a vármegyéig, s. 51.

${ }^{12}$ KRISTÓ, Gyula: A XI. századi hercegség története Magyarországon. Budapest : Akadémiai Kiadó, 1974, s. 46.

${ }^{13}$ KRISTÓ, Gy.: A XI. századi hercegség, s. 46. Dodajme, že Gyula Kristó urobil tol'ko ústupkov, že Kopáňov titul „dux” a v prípade výpravy Henricha III. v roku 1042 nepovažoval za nepredstavitel'né, že mohli súvisiet's nejakým predchádzajúcim územným rozdelením. Pozri KRISTÓ, Gy:: A XI. századi hercegség, s. 58.
} 


\section{Dániel Bagi}

podl'a neho, usadilo slobodné obyvatel'stvo, ktoré v dobe vzniku uhorského „feudálneho štátu“ a jeho upevnenia v 11. storočí unikalo pred „feudálnou mocou“. Král'ovská moc (regnum) sa usilovala, aby si týchto slobodných l'udí podrobila, v čom vojvodstvo, respektíve vojvodská moc hrali hlavnú úlohu. ${ }^{14}$ Gyula Kristó sa, opät' v protiklade k názorom Györgya Györffyho, domnieval, že vojvodstvo pozostávalo z dvoch častí. Strediskom jednej z nich bola Nitra, kým druhým mohol byt’ Bihar. ${ }^{15}$ Okrem toho Gyula Kristó, vyvracajúc skoršie názory, príznačné pre predvojnových predstavitel'ov mad'arskej historiografie, nepovažoval vznik vojvodstva za dynastickú záležitost', ale jeho vytvorenie a existenciu vysvetl'oval ako všeobecnú spoločenskú zákonitost'. Navyše zdôraznil úlohu rozličných mocenských skupín, stojacich medzi král'mi a vojvodami, a to najmä v závere 11 . storočia, ked' regnum a ducatus boli v opozícii.

Už Henrik Marczali si myslel, že v krajinách, kde dynastia sama vytvára mocenské štruktúry, v tomto prípade okrem Uhorska aj v Pol'sku a v Čechách, zaobchádza vládnuci rod s krajinou ako so svojím domíniom. „Vlastníctvo krajiny“ tak vedie k vnútrodynastickým sporom. ${ }^{16}$ Táto línia historiografie skúmala vojvodstvo v okruhu otázok nástupníckeho práva. Vo vojvodstve 11 . storočia videla v prvom rade konečný výsledok dynastického majetkovoprávneho sporu a prax delenia krajiny spájala bud' s nejakým nástupníckym modelom, zakladajúcim sa na normatívnom práve, ${ }^{17}$ alebo práve naopak, zdôvodňovala ju nezrelost'ou a nestálost'ou pravidiel dedenia trónu. ${ }^{18}$

Dnes je už jasnejšie, že dva modely rozvoja štátu, načrtnuté Györgyom Györffym a Gyulom Kristóm, presne zodpovedajú dvom zásadným chápaniam rozvoja štátu, aktuálnym v stredovýchodnej Európe v druhej polovici 20. storočia. Jeden z nich hl'adal pôvod štátu v dávnej minulosti národných dejín, kým druhý, nedbajúc o národný výklad, sa snažil dospiet' $\mathrm{k}$ výsledku prostredníctvom štrukturálnych analógií. Zaujímavost'ou oboch teórií je, že sa zrodili v protiklade k východiskám dvoch vel'kých línií klasickej českej, respektíve medzivojnovej a povojnovej československej historiografie, prípadne sa o ne opierajúc. Jedným z nich je teória kontinuity medzi přemyslovskými Čechami a Vel'komo-

\footnotetext{
${ }^{14}$ KRISTÓ, Gy.: A XI. századi hercegség, s. 82-86.

${ }^{15}$ KRISTÓ, Gy.: A XI. századi hercegség, s. 91-92.

${ }^{16}$ MARCZALI, H.: Magyarország története az Árpádok korában, s. 59.

${ }^{17}$ BARTONIEK, Emma: Az Árpádok trónöröklési joga. In: Századok. roč. 60, č. 9-10, 1926, s. 785-841; RUGONFALVI KISS, I.: Trónbetöltés és ducatus, s. 733-765, 849-868; RUGONFALVI KISS, István: Trónbetöltés és ducatus az Árpád-korban. In: Századok. roč. 63, 1929, s. 202-210; DOMANOVSZKY, S.: Az Árpádok trónöröklési jogához, s. 49.

${ }^{18}$ DEÉR, J.: Pogány magyarság, s. 126.
} 
Nové možnosti prístupu k výskumu dejín vojvodstva v 11. storočí

ravskou ríšou. Korene tejto predstavy skutočne môžu pochádzat’ zo stredoveku, avšak až z Kosmovej kroniky zo začiatku 12. storočia. Prvý historik Přemyslovcov nám zanechal príbeh úpadku Svätoplukovej Vel'komoravskej ríše. ${ }^{19}$ Tvrdí, že ríšu Moravanov zdedili čiastočne Česi, čiastočne Poliaci a Uhri, takže Vel'komoravská ríša prežívala d'alej v týchto štátoch. Samozrejme, Kosmom vymyslená teória translatio regni žila d’alej výlučne v českej dynastickej historiografii. Kroniky zo 14. storočia, Dalimilova a Pulkavova, nielenže prevzali, ale aj doplnili príbeh, v ktorom okrem ríše Moravanov pripadla Čechom aj moravská koruna. ${ }^{20}$ Už v druhej polovici 20. storočia prebehli pokusy o dekonštrukciu teórie o vel'komoravskom pôvode a teórie kontinuity. František Graus úspešne preukázal, že motív translatio regni bol obl'úbenou súčast’ou literatúry 12. storočia, ${ }^{21}$ iní zase presvedčivo dokázali, že Kosmov príbeh slúžil v prvom rade na potvrdenie „anexie“ Moravy začiatkom 11. storočia. ${ }^{22}$ Tieto dekonštrukčné snahy mali len čiastočný úspech. Kosmom vytvorená teória o (vel’ko)moravsko-českej kontinuite sa ukázala natol'ko úspešná, že dokázala vytvorit' symbiózu aj s marxisticko-leninskou historiografiou. ${ }^{23} \mathrm{Aj}$ moderná poprevratová česká medievistika bola len čiastočne ochotná sa od nej vzdialit', príznačne kvôli inej teórii kontinuity.

${ }^{19}$ Eodem anno Zuatopluk rex Moravie, sicut vulgo dicitur, in medio exercitu suorum delituit et nusquam comparuit. Sed re vera tum in se ipsum reversus, cum recognovisset, quod contra dominum suum imperatorem et compatrem Arnolfum iniuste et quasi inmemor beneficii arma movisset qui sibi non solum Boemiam, verum etiam alias regiones hinc usque ad flumen Odram et inde versus Ungariam usque ad fluvium a Gron subiugarat penitentia ductus medie noctis per opaca nemine sentiente ascendit equum et transiens sua castra fugit ad locum in latere montis Zober situm, ubi olim tres heremite inter magnam et inaccessibilem hominibus silvam eius ope et auxilio edificaverant ecclesiam. Quo ubi pervenit, ipsius silve in abdito loco equum interfecit et gladium suum humi condidit et, ut lucescente die ad heremitas accessit, quis sit illis ignorantibus, est tonsuratus et heremitico habitu indutus et quamdiu vixit, omnibus incognitus mansit, nisi cum iam mori a cognovisset, monachis semetipsum quis sit innotuit et statim obiit. Cuius regnum filii eius pauco tempore, sed minus feliciter tenuerunt, partim Ungaris illud diripientibus, partim Teutonicis orientalibus, partim Poloniensibus solo tenus hostiliter depopulantibus. BRETHOLZ, Bertold (ed.): Cosmae Pragensis Chronica Boemorum, Lib. I. c. 14. In: Monumenta Germaniae historica. (d'alej len MGH) Scriptores rerum Germanicarum. (d'alej len SRG) Nova series 2. Berlin : Weidmann, 1923, s. 32-33.

${ }^{20}$ KRČMOVÁ, Marie (ed.): Kronika tak řečeneho Dalimila. c. 24. Praha : Paseka, 2005, s. 47; EMLER, Josef (ed.): Kronika Pulkavova. In: Fontes rerum Bohemicarum (d'alej len FRB) V. Praha : Nákladem nadání Františka Palackého, 1893, s. 15-17.

${ }^{21}$ GRAUS, František: Velkomoravská říše v české středověké tradici. In: Československý časopis historický. roč. 11, 1963, s. 289-305; GRAUS, František: Die Entstehung der mittelalterlichen Staaten in Mitteleuropa. In: Historica 10. 1965, s. 5-65.

22 WIHODA, Martin: Kosmas a Vratislav. In: Querite primum regnum Dei. Sborník př́spěvků k poctě Jany Nechutové. Ed. Anna Pamprová, Dana Ražčiková, Libor Švanda et alii, Brno : Matice moravská, 2006, s. 367-381.

${ }^{23}$ Bez nároku na úplný výpočet prác: POULÍK, Josef (ed.): Großmähren und die Anfänge der tschechoslowakischen Staatlichkeit. Praha : Academia, 1986; RATKOŠ, Peter (ed.): Pramene k dejinám Vel'kej Moravy. Bratislava : Vydavatel'stvo Slovenskej akadémie vied, 1968; 


\section{Dániel Bagi}

Takto sa napr. David Kalhous prostredníctvom hagiografie svätého Václava snaží preukázat', že Přemyslovci aspoň spočiatku d'alej udržiavali staromoravské tradície, ${ }^{24}$ kým Martin Wihoda sa pokúšal pomocou sociálno-historickej teórie Otta Brunnera dokázat' previazanost' medzi starou Moravou a Čechami 11. - 12. storočia, zdôrazňujúc kontinuitu stredných vrstiev staromoravskej spoločnosti 10. - 11. storočia. ${ }^{25}$ Pri pohl'ade na teóriu vojvodstva Györgya Györffyho je badat', že Györffy predstavil svojrázny, autochtónny uhorský model, ktorý bol konkurencieschopný česko-moravským a iným slovanským teóriám o pôvode štátov, ktorých stredobodom bola „štátnost““ Moravy, respektíve jej vzt’ah k českým dejinám.

Aj metodické východiská teórie vytvorenej Gyulom Kristóm sú odvodené z československej historiografie. V prvom rade československí a pol'skí historici vytvorili $\mathrm{v}$ šest'desiatych rokoch minulého storočia takzvaný stredo- a východoeurópsky model stredovekého štátu. Podstatou teórie pôvodne vypracovanej Františkom Grausom je zhruba toto: štruktúru regiónu stredovýchodnej Európy, konkrétne monarchií Přemyslovcov, Piastovcov a Arpádovcov v podstate charakterizovalo to, že moc panovníkov, opierajúcich sa v prvom rade o svoje hrady a t’ažko ozbrojený sprievod, siahala okrem cirkevných majetkov aj na všetko a na každého. To, na rozdiel od západoeurópskeho modelu, prakticky neumožňovalo vznik žiadnej inej samostatnej mocenskej štruktúry. ${ }^{26}$ Grausovu teóriu, stavajúcu na vel'mi silnej panovníckej moci, d'alej rozvíjal začiatkom sedemdesiatych rokov minulého storočia jeho žiak Dušan Třeštík, respektíve Třeštíkova manželka pol'ského pôvodu Barbara Krzemieńska. Kniežaciu moc - a zároveň podstatu stredoeurópskeho modelu vládnej moci - sformulovali tak, že panovníci prostredníctvom špeciálneho systému zaopatrenia, pomocou beneficiárov udržiavali pod svojou kontrolou celú krajinu, respektíve hrady, a samotný systém financovali v prvom rade z príjmov z obchodu

TŘEŠTíK, Dušan: Počátky Přemyslovců. Vstup Čechů do dějin (530 - 935). Praha : Nakladatelství Lidové noviny, 1997; TŘEŠTíK, Dušan: Eine große Stadt der Slawen namens Prag. Staaten und Sklaven in Mitteleuropa im 10. Jh. In: Boleslav II. Der Tschechische Staat um 1000, seine Herrscher und Ökonomik. Internationales Symposium, Praha 9-10. Februar 1999. Hg. von Petr Sommer, Praha : Filosofia, 2001, s. 93-138.

${ }^{24}$ KALHOUS, David: Anatomy of a Duchy. The Political and Ecclesiastical Structures of Early Přemyslid Bohemia. East Central and Eastern Europe in the Middle Ages 450 - 1450. Vol. 19. Leiden : Brill, 2012, s. 193-266.

${ }^{25}$ WIHODA, Martin: Morava v dobĕ knížecí 906 - 1197. Praha : Nakladatelství Lidové noviny, 2010. Ku kritike Wihodovej knihy: BAGI, Dániel: Hogyan jött létre a középkori Morvaország? Egy új könyv margójára. In: Aetas. roč. 27, č. 4, 2012, s. 233-249.

${ }^{26}$ GRAUS, F.: Die Entstehung der mittelalterlichen Staaten, s. 8-11. 
Nové možnosti prístupu k výskumu dejín vojvodstva v 11. storočí

$\mathrm{S}$ otrokmi prekvitajúceho $\mathrm{v}$ tejto oblasti $\mathrm{v}$ priebehu 11 . storočia. 27 Třeštík sa dokonca usiloval dokázat', že tí, ktorí platili panovníkom daň (tributum), sa stali majetkom panovníka (ius utendi, ius abutendi). ${ }^{28} \mathrm{Av}$ šak na podloženie správnosti svojej teórie nedokázal ani on uviest' iný zdroj než d'alšiu pasáž Kosmovej kroniky, povest' o Libuši. V nej Čechov, búriacich sa proti Libušinej matriarchát stelesňujúcej moci a želajúcich si vol'bu kniežat’a, poučuje samotná kňažná o podstate kniežacieho práva. Skôr ako poslala po Přemysla, nového kniežat'a, upozorňuje Čechov na takmer neobmedzenú moc kniežat. A na to, čoho sa dočkajú poddaní, ak si zvolia nové, silné knieža. ${ }^{29}$ Podl'a prívržencov tohto názoru československej historickej vedy sa rovnaký model uplatnil aj na Morave od začiatku 11. storočia. Centrum (Praha) si postupne, krok za krokom podmanilo za perifériu považovanú celú Moravu, závažne tým obmedzujúc, takmer zlikvidujúc slobodným ešte aj právo na vlastníctvo. ${ }^{30}$ Moc kniežat sa postupne rozšírila na všetky hradské obvody a takmer znemožnila vznik súkromných majetkov, ba dokonca súkromného vlastníctva. Aj novšia generácia českej medievistiky to spochybnila len čiastočne, nepopierajúc špeciálny, takmer už verejnoprávny vzt’ah medzi kniežatami a ranou šl'achtou, ale vyzdvihujúc, že úloha tejto ranej šl'achty v politike spočívala na kniežatami darovaných súkromných majetkoch.

${ }^{27}$ TŘEŠTÍK, Dušan: K sociální struktuře přemyslovských Čech. Kosmas o knížecím vlastnictví půdy i lidí. In: Československý časopis historický. roč. 19, 1971, s. 537-564; TŘEŠTíK, Dušan - KRZEMIEŃSKA, Barbara: Hospodářské zaklady raně středověkého státu ve střední Evropě (Čechy, Polsko, Uhry v 10. - 11. století). In: Československý časopis historický. roč 27, 1979, s. 113-130; TŘEŠTÍK, Dušan - ŽEMLIČKA, Josef: O modelech vývoje přemyslovského státu. In: Český časopis historický. roč. 105, 2007, s. 122-163.

${ }^{28}$ TŘEŠTíK, D.: K sociální struktuře, s. 538-539, 555.

${ }^{29} \mathrm{O}$ plebs miseranda nimis, que libera vivere nescit, et quam nemo bonus nisi cum vita amittit, illam vos non inviti libertatem fugitis et insuete servituti colla sponte submittitis. Heu tarde frustra vos penitebit, sicut ranas penituit, cum ydrus, quem sibi fecerant regem, eas necare cepit. Aut si nescitis, que sint iura ducis, temptabo vobis ea verbis dicere paucis. Inprimis facile est ducem ponere, sed difficile est positum deponere; nam qui modo est sub vestra potestate, utrum eum constituatis ducem an non, postquam vero constitutus fuerit, vos et omnia vestra erunt eius in potestate. Huius in conspectu vestra febricitabunt genua, et muta sicco palato adherebit lingua. Ad cuius vocem pre nimio pavore vix respondebitis: „Ita domine, ita domine”, cum ipse solo suo nutu sine vestro preiudicio hunc dampnabit et hunc obtruncabit, istum in carcerem mitti, illum precipiet in patibulo suspendi. Vos ipsos et ex vobis, quos sibi libet, alios servos, alios rusticos, alios tributarios, alios exactores, alios tortores, alios precones, alios cocos seu pistores aut molendinarios faciet. Constituet etiam sibi tribunos, centuriones, villicos, cultores vinearum simul et agrorum, messores segetum, fabros armorum, sutores pellium diversarum et coriorum. Filios vestios et filias in obsequiis suis ponet; de bubus etiam et equis sive equabus seu peccoribus vestris optima queque ad suum placitum tollet. Omnia vestra, que sunt potiora in villis, in campis, in agris, in pratis, in vineis, auferet et in usus suos rediget. Cosmae Pragensis Chronica Boemorum, Lib. I. c. 5. MGH SRG N. S. 2, s. 14.

${ }^{30} \mathrm{~K}$ pol'ským pomerom pozri MODZELEWSKI, Karol: Organizacja gospodarcza państwa Piastowskiego: X-XIII wiek. Wrocław : Ossolineum, 1975, s. 34-78. 


\section{Dániel Bagi}

Popri vel'kom kniežacom majetku sa teda od raných čias objavil aj súkromný majetok. ${ }^{31} 0$ tom svedčí listina (zachovaná však v neskoršom odpise), v ktorej istý Nemoj testamentárne zanecháva svoje majetky Vyšehradskej kapitule. ${ }^{32}$ Dôkazom životaschopnosti teórie vypracovanej Grausom, respektíve Třeštíkom je, že jej zdokonal'ovatel' na nej trval ešte aj v roku 2007, pravda, v tom čase už doplnenej o novší obsahový prvok, čím sa prakticky vrátil ku klasickému hodnotovému systému českej historiografie. Podl'a nej korene českého, a všeobecne stredo-východoeurópskeho rozvoja štátu vychádzajú z mocenských štruktúr ríše Karolovcov, ktoré sa zachovali sprostredkovaním Vel'komoravskou ríšou, a stali sa vzorom pre celú strednú Európu. ${ }^{33} \mathrm{Na}$ upresnenie pripomeňme, že Třeštík svojou novou teóriou, vypracovanou v sedemdesiatych rokoch minulého storočia, odporoval aj svojmu predchádzajúcemu stanovisku. Ako bádatel', znalý Kosmovej kroniky, bol totiž prvý, kto preukázal, že príbeh o Libuši nie je mytologickým trópom a beletristickou manierou, ale odráža zmýšl’anie doby boja o investitúru. Zdôraznením „kniežacieho absolutizmu“ si Kosmas jednoducho želal vylúčit’ zasahovanie rímskonemeckých panovníkov do vol'by českých kniežat. ${ }^{34}$

Čo sa týka druhej vel'kej historiografickej predstavy o král'ovskom vojvodstve, je rovnako otázne, či vojvodstvo bola čisto dynastická záležitost'. Proti teóriám znázorňujúcim vojvodstvo iba ako vnútornú vec panovníckej rodiny namietal už Elemér Mályusz, poukazujúc, že patrimoniálne král'ovstvo je umelou teóriou z 19. storočia, ktorá sa zrodila vo všeobecnej spoločenskej atmosfére po Viedenskom kongrese v roku $1815 .{ }^{35} \mathrm{~K}$ tomu môžeme dodat' nanajvýš len tol'ko, že autor teórie, Karl Ludwig von Haller (1768 - 1854), ktorý sa narodil a pôsobil vo Švajčiarsku, napísal svoju slávnu knihu o „náprave“ sústavy štátneho práva bez akýchkol'vek vážnejších právnych a historických vedomostí. ${ }^{36}$ Jej hlavná myšlienka presne odrážala základné princípy nového európskeho politického systému, vypracované na Viedenskom kongrese. Dôkazom jeho prenikavého úspechu je, že myšlienka neochvejne prežíva v štátoprávno-

\footnotetext{
31 WIHODA, M.: Morava v době knížecí, s. 142; KALHOUS, David: Mittelpunkte der Herrschaft und Cosmas von Prag. Zum Charakter der Macht des mittelalterlichen Fürsten. In: Frühgeschichtliche Zentralorte in Mitteleuropa. Studien zur Archäologie Europas 14. Hg. von Jiří Macháček, Šimon Ungerman. Bonn : Habelt, 2011, s. 673-674.

32 FRIEDRICH, Gustav (ed.): Codex diplomaticus et epistolaris regni Bohemiae I. (d'alej len CDB) Praha : Sumptibus comitiorum Regni Bohemiae, 1904 - 1907, s. 105-106, č. 100.

${ }^{33}$ TŘEŠTÍK, D. - ŽEMLIČKA, J.: O modelech vývoje, s. 125.

${ }^{34}$ TŘEŠTíK, Dušan: Kosmova Kronika. Studie $k$ počatkům českého dějepisectví a politického myšlení. Praha : Academia, 1968, s. 174-176.

${ }^{35}$ MÁLYUSZ, E.: A patrimoniális királyság, s. 37-49.

${ }^{36}$ HALLER, Karl Ludwig von: Restauration der Staats-Wissenschaft, oder Theorie des natürlich-geselligen Zustands der Chimäre des künstlich-bürgerlichen entgegengesetzt I. Winterthur : Steinerischen Buchhandlung, 1816.
} 
historických syntézach. ${ }^{37} \mathrm{~A}$ to aj napriek tomu, že sa novšiemu výskumu podarilo preukázat', že dedenie trónu nikdy nebola iba vnútorná záležitost' dynastie. Nástupníctvo a s tým súvisiace delenie majetku zaujímalo okrem priamo účastných $\mathrm{v}$ prvom rade vel'možov patriacich do sprievodu príslušníkov dynastie, ktorým nebolo l'ahostajné ani to, kto spomedzi členov dynastie a čo zdedí z rodinného vlastníctva, ked'že to mohlo zásadne ovplyvnit' aj ich vlastné d'alšie osudy. ${ }^{38}$

Avšak nezávisle od teórie patrimoniálneho král'ovstva, dodnes nebola zodpovedaná otázka, či nástupnícke právo, existujúce v rámci dynastie, mohlo mat' nejakú úlohu v dejinách vojvodstva v 11 . storočí. V tomto ohl'ade väčšina historikov odjakživa zastávala názor, že starodávne dedičné zriadenie uprednostňovalo najstaršieho príslušníka rodu pred ostatnými. Seniorát, ktorý podl'a jednej z línií historiografie existoval ako súčast' nástupníckeho systému rozšíreného vo východnej a strednej Európe ${ }^{39}$ sa ešte v 11. storočí, práve pri delení krajiny medzi Arpádovcami, ocitol v protiklade $\mathrm{k}$ uprednostňovaniu priamych potomkov pred bočnou vetvou. A to viedlo ku konfliktom medzi členmi dynastie. ${ }^{40} \mathrm{~V}$ tejto súvislosti možno teóriu, ktorú neskôr prijal György Györffy, odvodit' od Istvána Rugonfalviho Kissa, o tom, že vojvodstvo chránilo bratov, ktorí chceli dedit’ podl'a starodávneho nástupníckeho princípu (successio gradualis), pred svojvôl'ou panovníkov podporovaných radami ich zahraničných manželiek a cudzozemských vel'možov. Takýmto spôsobom bolo samotné vojvodstvo v prenesenom význame nástupníckou inštitúciou. ${ }^{41}$ Seniorát ako právnu inštitúciu sa usiloval

\footnotetext{
${ }^{37}$ Pozri napríklad MEZEY, Barna: Képviselet és alkotmány a középkori Európában. Budapest : Rejtjel, 1998, s. 201, 206.

${ }^{38}$ BECHER, Mathias: Dynastie, Thronfolge und Staatsverständnis im Frankenreich. In: Der Frühmittelalterliche Staat - europäische Perspektiven. Hg. von Walter Pohl, Veronika Wieser, Wien : Verlag der Österreichischen Akademie der Wissenschaften, 2009, s. 198.

${ }^{39}$ LÜBKE, Christian: Das östliche Europa. München : Siedler Verlag, 2004, s. 290-322; FONT, Márta: A keresztény nagyhatalmak vonzásában. Közép-és Kelet-Európa a 10-12. században. Budapest : Balassi, 2005, s. 169-210.

${ }^{40}$ PAULER, Gy.: A magyar nemzet története I, s. 21, 175-176, 104; TIMON, Ákos: Magyar alkotmány- és jogtörténet. Budapest : Politzer Zsigmond és Fia, 1902, s. 103; BARTONIEK, Emma: A magyar királyválasztási jog a középkorban. In: Századok. roč. 70, č. 9-10, 1936, s. 359-406; BARTONIEK, Emma: A magyar királykoronázások története. Budapest : Akadémiai Kiadó, 1987, s. 8-11; ECKHART, Ferenc: Magyar alkotmány- és jogtörténet. Budapest : Politzer Zsigmond és Fia, 1946, s. 80-82; GYÖRFFY, György: Tanulmányok a magyar állam eredetéről. A nemzetségtől a vármegyéig, a törzstől az országig. Kurszán és Kurszán vára. Budapest : Akadémiai Kiadó, 1959, s. 137; GYÖRFFY, György: István király, s. 33, 376; DÜMMERTH, Dezső: Az Árpádok nyomában. Budapest : Panoráma, 1977, s. 232-233; KRISTó, Gyula (Szerk.): Korai magyar történeti lexikon (9-14. század). Budapest : Akadémiai Kiadó, 1994 (d’alej len KMTL), s. 599 (autor István Tringli).

${ }^{41}$ RUGONFALVI KISS, I.: Trónbetöltés és ducatus, s. 747.
} 


\section{Dániel Bagi}

vyvrátit' už Sándor Domanovszky. ${ }^{42}$ Vážne argumenty proti nej sa objavili aj v novšej mad'arskej medievistike. Attila Zsoldos upozornil na to, že uplatnenie dedičského práva dynastie bolo jediným skutočným nástupníckym poriadkom do konca 12 . storočia. ${ }^{43}$ Kornél Szovák poznamenal, že v priebehu 11. storočia ani seniorát, ani primogenitúra nemohli zohrávat' prednostnú úlohu, pretože panovnícke právo na určenie nástupcu bolo postavené nad obe z nich. ${ }^{44}$ Existencia alebo absencia seniorátu a primogenitúry, respektíve právno-inštitučných nástupníckych modelov je samostatnou otázkou, a žiadala by si porovnávaciu štúdiu aspoň na regionálnej úrovni. Vo všeobecnosti však môžeme poznamenat': v prvom rade by bolo nutné vyjasnit', čo možno považovat' za právo v 11. storočí. Medzinárodným výskumom sa v uplynulých desat'ročiach podarilo preukázat', že normatívna právna regulácia, ako aj zvykové právo prinajmenšom pred 13. storočím ustúpilo do úzadia pred systémom právnych vzt'ahov na slovnej báze, vzt'ahujúcim sa na jednotlivé prípady. „Právna prax“ nefungovala na základe vypracovaných normatívnych pravidiel, ale v každej situácii sa výsledok ústneho rokovania medzi dotyčnými stal dočasnou normou, a ak sa aj počas sporov strany odvolávali na nejaké „práva“, tie boli skôr len argumentmi slúžiacimi na vzájomné presviedčanie, nie skutočnými písanými právnymi predpismi. ${ }^{45}$ To už vopred spochybňuje, či je možné hovorit' o akomkol'vek normatívnom práve $\mathrm{v}$ súvislosti s nástupníctvom. $\mathrm{Na}$ druhej strane je isté, že dedenie trónu nemohlo byt' iba vnútornou záležitost'ou dynastie. K úspešnemu ustanoveniu panovníka bola potrebná dohoda a vyrovnanie sa s elitami okolo dynastie, čiže v nástupníctve zohrával ovel’a väčšiu úlohu konsenzus vytvorený v aktuálnej situácii, než akýkol'vek iný činitel'.

\footnotetext{
42 DOMANOVSZKY, S.: Az Árpádok trónöröklési jogához, s. 51-52.

${ }^{43}$ ZSOLDOS, Attila: Az Árpádok és alattvalóik. Magyarország története 1301-ig. Debrecen : Csokonai Kiadó, 1997, s. 45.

${ }^{44} \mathrm{~K}$ tomu pozri štúdiu Kornéla Szováka v: Képes krónika. Fordította Bollók János. A fordítást gondozta és a jegyzeteket készítette Szovák Kornél és Veszprémy László, az utószót írta, a függeléket és az irodalomjegyzéket összeállította Szovák Kornél. Budapest : Osiris, 2004, s. 247.

${ }^{45}$ Vo vzt'ahu k ríši pozri VOLLRATH, Hannah: Herrschaft und Genossenschaft im Kontext frühmittelalterlicher Rechtsbeziehungen. In: Historisches Jahrbuch 102. 1982, s. 38; PATZOLD, Steffen: Königserhebungen zwischen Erbrecht und Wahlrecht? In: Deutsches Archiv für Erforschung des Mittelalters 58. 2002, s. 476. Vo zvt'ahu k Francúzsku 11. - 12. storočia pozri napr. WHITE, Stephen D.: Custom, Kinship and Gift to Saints: The Laudatio Parentum in Western France 1050 - 1150. Chapel Hill : University of North Carolina Press, 2011, s. 7071; WHITE, Stephen D.: Pactum... Legem Vincit and Amor Iudicium: The Settlement of Disputes by Compromise in Eleventh Century Western France. In: The American Journal of Legal History 22. 1978, s. 305.
} 
Nové možnosti prístupu k výskumu dejín vojvodstva v 11. storočí

II.

Historici sa usilovali nájst' odpoved' na otázku pôvodu král'ovského vojvodstva v dvoch smeroch. Ak chceme vediet', čo vojvodstvo bolo, treba uplatnit' dve hl'adiská. Jedno hl'adá analógie v podobných európskych štruktúrach a druhé sa zameriava na pramene dokazujúce existenciu král'ovského vojvodstva, z ktorých sa môžeme dozvediet' o tom, že Uhorsko sa v 11. storočí rozdelilo.

Čo sa týka možnosti jeho začlenenia do väčších modelov, už Gyula Kristó vo vyššie citovanej monografii o král'ovskom vojvodstve na rozdiel od Györffyho nenachádzal vzory vojvodstva v uhorských dejinách, ale v skorších a súvekých európskych javoch. Ním menované príklady sa vzt'ahujú na dobu merovejskej a karolovskej dynastie, takisto sa týkali „vojvodstiev" spravovaných Piastovcami a Přemyslovcami v $11-12$. storočí. ${ }^{46}$ Dokonca vo svojej práci o feudálnej rozdrobenosti zaradil tieto „vojvodstvá“ do troch odlišných skupín podl'a toho, $v$ akej forme existovali. Rozlišoval medzi podoblast'ami vlastnenými členmi dynastie, podoblast'ami ovládanými súkromnými majitel'mi a takzvanými sukcesívnymi regionálnymi vládami, ktoré vznikli kombináciou predošlých dvoch foriem. ${ }^{47} \mathrm{Aj}$ ked' filozoficko-historické rámce, použité pre porovnávací model, medzitým stratili platnost', niet pochýb o tom, že Gyula Kristó bol prvý, kto učinil z dejín vojvodstva 11 . storočia predmet systematického porovnávacieho výskumu. Zásadnú správnost' jeho metódy potvrdzuje, že v medievistickom výskume, v medzinárodnom ${ }^{48} \mathrm{i}$ mad'arskom ${ }^{49}$ bol poskytnutý priestor pre

${ }^{46}$ KRISTÓ, Gy.: A XI. századi hercegség, s. 11-30.
47 KRISTÓ, Gyula: A feudális széttagolódás Magyarországon. Budapest : Akadémiai Kiadó,
1979, s. 23.
48 LÜBKE, Ch.: Das östliche Europa, passim. Z hl'adiska štrukturálnej analýzy historiografie,
resp. písomníctva pozri ADAMSKA, Anna: The Introduction of Writing in Central Europe
(Poland, Hungary and Bohemia). In: New Approaches to Medieval Communication. Ed.
Marco Mostert. With an Introduction by Michael Clanchy. Turnhout: Brepols, 1999, s. 165-
190; ADAMSKA, Anna: The Study of Medieval Literacy. Old Sources, New Ideas. In: The
Development of Literate Mentalities in East-Central Europe. Ed. Anna Adamska, Marco
Mostert. Turnhout: Brepols, 2004, s. 13-47; KERSKEN, Norbert: Mittelalterliche National-
geschichtsschreibung im östlichen Mitteleuropa. In: Mediaevalia Historica Bohemica 4.
1995, s. 147-170; KERSKEN, Norbert: Die Anfänge nationaler Geschichtsschreibung im
Hochmittelalter: Widukind von Corvey, Gallus Anonymus, Cosmas von Prag, Gesta Hunga-
rorum. In: Europas Mitte um 1000. Beiträge zur Geschichte, Kunst und Archäologie 2. Hg. von
Alfred Wieczorek, Hans-Martin Hinz, Stuttgart : Theiss, 2000, s. 863-867; KERSKEN,
Norbert: Mittelalterliche Geschichtsentwürfe in Alt und Neueuropa. In: Die Geschichts-
schreibung in Mitteleuropa. Projekte und Forschungsprobleme. Hg. von Jarosław Wenta.
Toruń : Wydawnictwo Uniwersytetu Nikołaja Kopernika, 1999, s. 111-134; VESZPRÉMY,
László: Árpád-kori történeti elbeszélő forrásaink (11-13. század) nyugat-európai kapcsola-
tai. MTA doktori értekezés. (rukopis) Budapest 2007.
49 V mad'arskej historiografii pozri najmä FONT, M.: A keresztény nagyhatalmak, passim. K
súbežnému výskumu vojvodstva a česko-moravských záležitostí pozri najnovšie KOSZTA, 
regionálnu komparatívnu analýzu, dotýkajúcej sa oblasti pomenovanej po spoločnej dohode ako stredovýchodná Európa. Tak sa nám ponúka zaujímavá otázka, či sa dá porovnat' raný systém rozdelenia moci Arpádovcov s okolitými, v prvom rade pol'skými a českými modelmi a ak áno, tak do akej miery je porovnatel'ný a či je možné ho odsledovat' aj z nejakej staršej, prípadne franskej štruktúry? Porovnanie, prinajmenšom na regionálnej úrovni, má aj d'alší, do vel'kej miery praktický dôvod a to kriticky malý počet prameňov. Nie je potrebné podrobnejšie vysvetl'ovat', ako táto okolnost' vo vel'kej miere st'ažuje výskum raných etáp uhorských dejín. ${ }^{50} \mathrm{~V}$ tomto ohl'ade poskytuje len málo útechy, že to všetko platí aj pre stredoveké pol'ské a české pramene, ktoré sú najvhodnejšie pre komparáciu s uhorskými.

To nás núti položit' si otázku, odkial' vieme o existencii vojvodstva. Odhliadnuc od hore citovaného zákona Kolomana, z ktorého sa dozvedáme len tol'ko, že král' aj vojvoda mali majetky, aj od nepočetných listinných prameňov, v ktorých sa sem-tam naraz objavujú králi a vojvodovia, máme $\mathrm{k}$ dispozícii v prvom rade rozprávacie pramene. $\mathrm{Z}$ nich je naším najdôležitejším prameňom Uhorská kronika, čiže Kronikárska skladba zo 14. storočia. ${ }^{51}$ Predovšetkým z nej poznáme okolnosti vzniku vojvodstva, boje o trón medzi vojvodami a král'mi v druhej polovici 11 . storočia a na začiatku 12. storočia. Mad'arskej medievistike, opierajúc sa predovšetkým o údaje kronikárskej skladby, sa podarilo lokalizovat’ domnelé hlavné strediská vojvodstva. Nepotrebuje d'alšie vysvetlenie, akou stratou pre mad'arskú medievistiku je, že kroniku zahrňujúcu udalosti uhorských dejín 11. storočia poznáme len $\mathrm{z}$ textového korpusu, ktorý sa nám zachoval $\mathrm{v}$ zopár textových súboroch. Obsahuje texty od druhej polovice 11. storočia postupne sa rozširujúce, respektíve dodatočne zmenené - interpolované a všetkými inými spôsobmi skrátené, rozšírené a rôzne zdeformované. Z toho vyplýva, že vo výskume Uhorskej kroniky hrali hlavnú úlohu $\mathrm{v}$ prvom rade dôkladné a podrobné filologické rozbory. Pomocou nich mad’arská veda v skúmaní textu kronikárskej kompozície dosiahla za

László: A hradištei bencés monostor alapításának magyar vonatkozásai. In: Ünnepi kötet Dr. Blazovich László egyetemi tanár 70. születésnapjára. Acta Universitatis Szegediensis. Acta Juridica et Politica 75. Szerk. Balogh Elemér, Homoki-Nagy Mária, 2013, s. 403-426.

${ }^{50}$ VESZPRÉMY, L.: Árpád-kori történeti elbeszélő forrásaink, s. 8. Pozri aj KRISTÓ, Gyula: $A$ történeti irodalom Magyarországon a kezdetektól 1241-ig. Budapest : Argumentum, 1994; KRISTÓ, Gyula: Magyar historiográfia I. Történetírás a középkori Magyarországon. Budapest : Osiris, 2003.

51 DOMANOVSZKY, Alexander (ed.): Chronici Hungarici compositio saeculi XIV. In: Scriptores rerum Hungaricarum tempore ducum regumque stirpis Arpadianae gestarum I. (d’alej len SRH) Edendo operi praefuit Emericus Szentpétery. Az Utószót és a Bibliográfiát összeállította, valamint a Függelékben közölt írásokat az I. kiadás anyagához illesztette Szovák Kornél és Veszprémy László. Budapest : Nap Kiadó, 1999, s. 219-505. 
posledné polstoročie vel'mi významný pokrok. ${ }^{52}$ A môžeme len dúfat', že d'alšie filologické výskumy lepšie objasnia d'al'šie otázky.

Popri v širokom zmysle chápanom gramatickom bádaní exituje aj iný - od neho zrejme neoddelitel'ný, a predsa sl’ubujúci nové výsledky - spôsob prístupu výkladu kronikárskych textov. Európska medievistika dosiahla v uplynulých niekol'kých desat'ročiach vel'mi vážny pokrok v oblasti skúmania rozprávacích prameňov a politických konfliktov. Bádatel'ský záujem sa popri čisto textových kritikách čoraz dôraznejšie obracal na symbolický výklad príbehov. Príbehy v stredovekých rozprávacích prameňoch vykladala romantická, historizujúca a pozitivistická historiografia takmer doslova a z nich rekonštruovala hlavné udalosti národných dejín obdobia stredoveku. Od objavenia sa duchovných dejín (Geistesgeschichte), presadzovaných Wilhelmom Diltheym (1833 - 1911), pokúšali sa historiografické prúdy 20. storočia dekonštruovat' a podl'a nových aspektov znova vyložit' obsah prameňov. V tomto ohl'ade sa najd'alej dostal postmoderný prístup, ktorý sa objavil po druhej svetovej vojne a stal sa populárnym od šest'desiatych rokov minulého storočia. Pomocou metodického smeru zvaného „new philology“, ktorý študoval texty samé o sebe, nevšímajúc si ich historický kontext, sa bádatel'om uplatňujúcim postmodernú metodológiu podarilo príbehy rozprávacích prameňov prakticky rozobrat' na atómy, vyčleniac z nich dejiny, zbaviac ich spoločensko-historického kontextu, považujúc texty za jednoduché, aj samé o sebe jestvujúce jazykovo-štrukturálne útvary. ${ }^{53}$ Nezávisle od smerov nikam nevedúcich, krajne deštruktívnych a nepotrebných pre medievistické výskumy, zrodili sa aj nové metodické inovácie, analyzu-

\footnotetext{
52 GERICS, József: Legkorábbi gesta-szerkesztéseink keletkezésrendjének problémái. Értekezések a történeti tudományok köréből. Új sorozat 22. Budapest : Akadémiai Kiadó, 1961; MÁLYUSZ, Elemér - KRISTÓ, Julius: Johannes de Thurocz Chronica Hungarorum II. Commentarii I - II. Budapest : Akadémiai Kiadó, 1988; KRISTÓ, Gy.: A történeti irodalom Magyarországon, s. 8-22; VESZPRÉMY, László - SZOVÁK, Kornél: Krónikák, Legendák, Intelmek. Utószó. In: SRH II, s. 750-761; SZOVÁK, Kornél: In: Képes krónika. Fordította Bollók János, s. 239-254; THOROCZKAY, Gábor: A magyar krónikairodalom kezdetei. In: Aktualitások a magyar középkorkutatásban. Szerk. Font Márta, Fedeles Tamás, Kiss Gergely, Pécs : Pécsi Tudományegyetem, Bölcsészettudományi Kar, 2010, s. 23-34; SZŐCS, Tibor: A 14. századi krónikaszerkesztmény és 11 . századi okleveleink. In: Fons. roč. 14, č. 1, 2007, s. 59-95; VESZPRÉMY, László: Korhűség és forrásérték a magyar Krónika egyes fejezeteiben. In: Arcana tabularii. Tanulmányok Solymosi László tiszteletére II. Szerk. Bárány Attila, Dreska Gábor, Szovák Kornél. Budapest - Debrecen : Magyar Tudományos Akadémia, Debreceni Egyetem, Eötvös Loránd Tudományegyetem, Pázmány Péter Katolikus Egyetem, 2014, s. 809-824

${ }^{53}$ Ciel'om tejto štúdie nemôže byt' detailné predstavenie jednotlivých postmoderných či iných bádatel'ských smerov. Ako nevel'mi prít'ažlivý všeobecný prehl'ad pozri SPIEGEL, Gabrielle M.: The Past as Text: The Theory and Practice of Medieval Historiography. Baltimore : Johns Hopkins University Press, 1997.
} 


\section{Dániel Bagi}

júce výklad prameňov pomocou skutočne nových a konštruktívnych metód. Bola to francúzska škola Annales, ktorá výrazne ovplyvnila aj povojnové generácie historikov a ktorá skúmala spoločensko-historické štruktúry z dlhodobého hl'adiska, preukazujúc zmenu štruktúr pomocou prameňov. Povojnové západonemecké medievistické školy, počnúc Helmutom Beumannom, stavali do centra svojho bádania dejiny autorov naračných prameňov. ${ }^{54}$ Gerd Althoff od začiatku devät'desiatych rokov 20. storočia a časom aj viacerí členovia ním vedenej takzvanej münsterskej školy prišli so štúdiami s novým prístupom. Na jednej strane zužitkovali výsledky spoločensko-historického výskumu, ktorý prebiehal v historickej vede už od začiatku 20. storočia, a na druhej strane ako základ skúmania vyzdvihli preukázatel'nú symbolickú komunikáciu. Podarilo sa preukázat', že rozprávacie pramene 9. - 12. storočia neboli kusými rozprávaniami, ale presne odrážali predstavy dobových gramotných elít o svete a svetovom usporiadaní okolo nich. ${ }^{55}$ Stredoveké právo rozlišovalo medzi slobodnými a neslobodnými. ${ }^{56}$ Určovalo právne postavenie dvoch vel'kých vrstiev stredovekej spoločnosti, presnejšie tých, ktorí spadali do rozličných kategórií slobody. Popri tomto organizačnom princípe, či dokonca nezávisle od neho, existovala $\mathrm{v}$ prvom rade teologicky založená idea, ktorá rozdel'ovala svet na tri (niekedy štyri) funkčné alebo vertikálne stavy a obyvatel'ov krest'anského sveta kategorizovala podl'a funkcií zastávaných vo svete. Rozlišovala stav bojovníkov, modliacich sa a

\footnotetext{
${ }^{54} \mathrm{~K}$ predchádzajúcim pokusom v tejto oblasti pozri BEUMANN, Helmut: Widukind von Korvei. Weimar : Böhlau, 1950, s. 6-8; BEUMANN, Helmut: Die Historiographie des Mittelalters als Quelle für die Ideengeschichte des Königtums. In: Historische Zeitschrift 160. 1955, s. 451453; GOETZ, Hans-Werner: Das Geschichtsbild Ottos von Freising. Ein Beitrag zur historischen Vorstellungswelt und zur Geschichte des 12. Jahrhunderts. Beihefte zum Archiv für Kulturgeschichte 19. Köln - Wien : Böhlau, 1984, s. 8-16. Sumárny prehl'ad moderných historiografických metodologických smerov pozri GOETZ, Hans-Werner: Moderne Mediävistik. Stand und Perspektiven der Mittelalterforschung. Darmstadt : Primus, 1999.

${ }^{55}$ FICHTENAU, Heinrich: Lebensordnungen des 10. Jahrhunderts. Studien über Denkart und Existenz im einstigen Karolingerreich. Stuttgart : Anton Hiersemann, 1984. K predstavám a problému pramennej kritiky pozri GOETZ, Hans-Werner: „Vorstellungsgeschichte”: Menschliche Vorstellungen und Meinungen als Dimension der Vergangenheit. Bemerkungen zu einem jüngeren Arbeitsfeld der Geschichtswissenschaft als Beitrag zu einer Methodik der Quellenauswertung. In: GOETZ, Hans-Werner: Vorstellungsgeschichte. Gesammelte Schriften zu Wahrnehmungen, Deutungen und Vorstellungen im Mittelalter. Hg. von Anna Aurast, Simon Elling et alii. Bochum : Winkler, 2007, s. 3-18.

${ }^{56}$ BOLLA, Ilona: A jogilag egységes jobbágyságról Magyarországon. Budapest : Akadémiai Kiadó, 1998, s. 16-17; JÂNOSI, Monika: Törvényalkotás a korai Árpád-korban. Szegedi Középkortörténeti Könyvtár 9. Szeged : Szegedi Középkorász Műhely, 1996, s. 67-130; ZSOLDOS, Attila: Szent István korának magyar társadalma. In: Kisebbségkutatás 9. 2000, s. 419425; SOLYMOSI, László: Társadalom Szent István korában. In: Államalapítás, társadalom, művelődés. Szerk. Kristó Gyula, Budapest : MTA Történettudományi Intézet, 2001, s. 55-65.
} 
pracujúcich. Avšak okrem týchto dvoch modelov poznáme aj tretie usporiadanie spoločnosti, ktoré upravovalo vzájomný vzt’ah slobodných v súlade s vertikálnym ordo. Tu môžeme rozlíšit' tri typy vzt'ahov: pokrvnú väzbu, účelový vzt'ah a hierarchicky podriadené a nadradené právne vzt'ahy. Základom všetkých troch kategórií bola amicitia, čiže priatel'stvo, pojem zdedený zo staroveku, ktorý značil politické, sociálne a citové zväzky. V stredoveku ho prechovávala krest’anská cirkev a existoval aj v merovejskej a karolovskej ére.$^{57}$ Gerd Althoff poukázal na to, že spoločenské vzt'ahy sa v karolovskej dobe, ale aj neskôr, zakladali na rovnosti, ${ }^{58}$ ktorej zárukou bolo prísahou potvrdené priatel'stvo. ${ }^{59}$ To zaručovalo poriadok vládnuci vo svete, dôveru verejnosti, a zároveň aj životaschopnost' spoločenských vzt'ahov. Tento systém sa v druhej polovice 11. storočia „dostal do krízy“ a zmenil sa. Podriadil si príbuzných a nepríbuzných a tak vznikla siet' vzt'ahov zakladajúca sa na novom druhu priatel'stva, v ktorej hlavnú úlohu hrali hierarchické vzt'ahy.

Rozprávacie pramene teda poskytujú jasný obraz o spoločenskom poriadku, prežívajúcom v myslení dobových elít a tak ponúkajú aj istý podklad o systéme vzt’ahov medzi účastníkmi dejín, v tomto prípade medzi Arpádovcami.

Na dôkaz toho, že to nie je len nepodložený dohad, môžeme podrobit' dôkladnejšiemu rozboru 88. kapitolu kronikárskej kompozície, ktorá okrem iného podáva správu o tom, akým spôsobom si podelili krajinu Ondrej I. a jeho brat Belo. Kronika tu hovorí nasledovné: „Ked’ král' Ondrej stratil brata, poslal poslov do Pol'ska k svojmu druhému bratovi Belovi s láskyplným odkazom: »Kedysi sme spoločne znášali núdzu a útrapy, môj milý brat, teraz t'a prosím, nemeškaj, príd' ku mne, aby sme sa mohli obaja rovnako delit' o radost' a spolu s radost'ou sa delit' aj o bohatstvo krajiny. Okrem teba nemám iného dediča ani súrodenca; ty bud' mojím dedičom, ty bud' mojím nasledovníkom v kral'ovaní.« Belu tieto slová dojali a s celou svojou rodinou prišiel ku král'ovi. Ked' ho král' uvidel, vel'mi sa zaradoval, ba až zajasal, pretože sa mohol spol'ahnút' na jeho

\footnotetext{
${ }^{57}$ EPP, Verena: Amicitia. Zur Geschichte personaler, sozialer, politischer und geistlicher Beziehungen im frühen Mittelalter. Stuttgart : Anton Hiersemann, 1999, s. 35-36; EPP, Verena: Rituale frühmittelalterlicher amicitia. In: Formen und Funktionen öffentlicher Kommunikation im Mittelalter. Hg. von Gerd Althoff. Stuttgart : Jan Thorbecke, 2001, s. 11-24.

${ }^{58}$ ALTHOFF, Gerd: Verwandte, Freunde und Getreue. Zum politischen Stellenwert der Gruppenbildungen im frühen Mittelalter. Darmstadt : Wissenschaftliche Buchgesellschaft, 1990, s. 89-91.

${ }^{59}$ FRITZE, Wolfgang: Die Fränkische Schwurfreundschaft der Merowingerzeit. Ihr Wesen und ihre politische Funktion. In: Zeitschrift für Savigny-Stiftung. Germanistische Abteilung. 71. 1954, s. 74-125. K vzájomnému pomeru prísahy a moci pozri BECHER, Mathias: Eid und Herrschaft. Untersuchungen zum Herrscherethos Karls des Großen. Vorträge und Forschungen. Sonderbände 39. Sigmaringen : Jan Thorbecke, 1993.
} 
neoblomnost' a nepoddajnost'. Potom sa král' a jeho brat Belo poradili a rozdelili krajinu na tri časti: dve tretiny patrili král'ovskej výsosti, teda zostali v moci král'a, jedna tretina pripadla do vlastníctva vojvodu Bela. Toto prvé rozdelenie Uhorska medzi vojvodami a král'mi sa stalo ohniskom sváru a rozbrojov.“60

Samozrejme, problémy ihned' začínajú tým, že nevieme, kedy presne vznikol tento úryvok kroniky, a tak či sa môže považovat' za hodnoverný prameň k dejinám vojvodstva. Už skoršia mad'arská medievistika poukázala na to, že táto kapitola je určite interpolovaná. Sándor Domanovszky tušil, že za písomným zaznamenaním výjavu sa skrýval autor gest z obdobia svätého Ladislava, zachytávajúc tradíciu Belovej vetvy. ${ }^{61}$ Podl'a Józsefa Gericsa a Gyulu Kristóa mohol text vsunút' ten autor, ktorý v 91. kapitole kroniky pokarhal Ondreja I., že urobil Šalamúna král'om. ${ }^{62} \mathrm{O}$ interpolácii 88. kapitoly nemôžu byt' ani podl'a nášho názoru pochybnosti. Správu o prvom rozdelení krajiny mohol napísat' iba autor, ktorému bolo jasné, že niečo také sa udialo aj neskôr. To skutočne odkazuje najskôr na dobu svätého Ladislava. Autor kroniky však umiestnil udalosti do širšieho kontextu, teda hovorí o vojnách, konfliktoch a vojvodoch, z čoho sa dá usúdit', že zápis mohol vzniknút' aj po odstavení Álmoša a konečnom zrušení vojvodstva, čiže opisuje udalosti z pohl'adu Kolomanovej doby. Aj podl'a jednohlasného úsudku mad'arského bádania, kronika alebo gesta z obdobia Kolomana v prvom rade rozprávajú o zápasoch vojvodov a Šalamúna, respektíve vláde svätého Ladislava. ${ }^{63}$ A tak sa môžeme oprávnene domnievat', že úseky kronikárskej skladby zahŕňajúce aj 88. kapitolu zostavil, prípadne si objednal niekto, kto si bol dokonale vedomý, kedy sa začali rozbroje vojvodov a král'ov a čo bolo presnou príčinou sporov o trón.

\footnotetext{
${ }^{60}$ Rex autem hic Andreas fratre orbatus misit in Poloniam ad alterum fratrem suum Belam cum magna dilectione vocans eum et dicens: „Nos qui quondam penurie participes fuimus et laborum, rogo te dilectissime frater, ut ad me non tardes venire, quatenus consortes simus gaudiorum et bonis regni corporali presentia gaudentes communicemus. Neque enim heredem habeo, nec germanum preter te. Tu sis michi heres, tu in regnum succedas. Post hec autem rex et frater eius Bela habito consilio diviserunt regnum in tres partes, quarum due in proprietatem regie maiestatis seu potestatis manserunt, tertia vero pars in proprietatem ducis est collata. Hec igitur prima regni huius divisio seminarium fuit discordie et guerrarum inter duces et reges Hungarie. Chronici Hungarici compositio saeculi XIV., c. 88. SRH I, s. 345. Slovenský preklad SOPKO, Július - LENGYELOVÁ, Tünde (eds.): Viedenská mal'ovaná kronika. Chronica Picta. Marek z Káltu. Bratislava : Perfekt, 2016, s. 210.

${ }^{61}$ DOMANOVSZKY, S.: Az Árpádok trónöröklési jogához, s. 49-50.

${ }^{62}$ GERICS, J.: Legkorábbi gesta-szerkesztéseink, s. 82-83; KRISTÓ, Gy.: A XI. századi hercegség, s. 67.

${ }^{63}$ GERICS, J.: Legkorábbi gesta-szerkesztéseink, s. 101; KRISTÓ, Gy.: A történeti irodalom Magyarországon, s. 8-22; SZOVÁK, K.: In: Képes krónika. Fordította Bollók János, s. 241-242; VESZPRÉMY, László: Megjegyzések korai elbeszélő forrásaink történetéhez. In: Századok. roč. 138 , č. 2, 2004, s. 328-329.
} 
Pre pochopenie pasáže 88. kronikárskej kapitoly je rozhodujúce tvrdenie v texte, ktoré rozdelenie krajiny považuje za príčinu rozbrojov medzi vojvodami a král'mi. Neznámy kronikár tu charakterizuje udalosti pojmami divisio regni a discordia, ktoré sú pre tento príbeh klúčové.

Pojem divisio regni je dôležitý terminus technicus politického jazyka stredoveku, a je bezprostredne vyvoditel'ný zo spisov Nového zákona. Podl'a jedného príbehu pochádzajúceho pravdepodobne z logionu ${ }^{64}$ a zachovaného v evanjeliu Matúša a Lukáša, vyčítali farizeji Ježišovi ohl’adom jedného jeho zázraku, že diabla vedel vyhnat' z chorej ženy len pomocou Belzebuba, ${ }^{65}$ na čo im Ježiš takto odpovedal: „Každé král'ovstvo vnútorne rozdelené spustne, a dom na dom sa zrúti. Ak aj diabol vyháňa diabla, ako by mohlo obstát' jeho král'ovstvo? Hovoríte, že vyháňam zlých duchov pomocou Belzebuba. Ale ak ja vyháňam zlých duchov pomocou Belzebuba, čou pomocou ich vyháňajú vaši synovia? Preto oni budú vašimi sudcami. Ale ak ja vyháňam zlých duchov Božím prstom, potom je už vám nablízku Božie král'ovstvo."66

Primárnou oblast’ou rozboru kronikárskeho príbehu je teológia. V rámci teológiou daných vymedzení dáva metafora „vnútorne rozdeleného král'ovstva" v prvom rade odpoved' pre pochybovačov o schopnostiach Ježiša konat' zázraky, a v širšom, dodnes platnom poňatí sa postoj farizejov stal jedným zo základných vzorov bohorúhania, respektíve neodpustitel'ných hriechov spáchaných proti Duchu Svätému: ved' tí, čo pochybovali o Ježišovi, priamo spochybňovali to, či je Božím poslom a Dávidovým synom. ${ }^{67}$

Avšak pojem divisio regni bol na politickom dejisku až od vzniku barbarských král'ovstiev a kniežatstiev, v prvom rade vo Franskej ríši, kde sa stal činitel’om mocenskej organizácie počnúc vládou Merovejovcov. ${ }^{68}$ Merovejovci a Karolovci sa usilovali na základe pokrvného práva zaopatrit’ každého mužského potomka dynastie $\mathrm{v}$ rovnakej miere $\mathrm{z}$ otcovského dedičstva. To sa mohlo uskutočnit' len tak, že všetci dostali za dedičstvo

\footnotetext{
${ }^{64}$ KLEIN, Hans: Das Lukasevangelium. Göttingen : Vandenhoeck \& Ruprecht, 2006, s. 411-417.

${ }^{65}$ quidam autem ex eis dixerunt in Beelzebub principe daemoniorum eicit daemonia, et alii temptantes signum de caelo quaerebant ab eo. Luk. 11, 15-16.

${ }^{66}$ Omne regnum in se ipsum divisum desolatur et domus supra domum cadet. Si autem et Satanas in se ipsum divisus est, quomodo stabit regnum ipsius? Quia dicitis in Beelzebub eicere me daemonia. si autem ego in Beelzebub eicio daemonia filii vestri in quo eiciunt ideo? Ipsi iudices vestri erunt. Porro si in digito Dei eicio daemonia profecto praevenit in vos regnum Dei. Luk. 11, 17-20.

${ }^{67}$ SCHNACKENBURG, Rudolf: God's Rule and Kingdom. London : Palm Publishers, 1963, s. $251-260$.

${ }^{68}$ Súhrnne pozri KASTEN, Brigitte: Königssöhne und Königsherrschaft. Untersuchungen zur Teilhabe am Reich in der Merowinger- und Karlingerzeit. MGH Schriften 44. Hannover : Hahnsche Buchhandlung, 1997.
} 
približne rovnako vel'ké časti krajiny. ${ }^{69}$ Ak možno verit' Františkovi Grausovi, tak korene tohto zvyku sa nenachádzajú v sakrálnosti Frankov. Frankovia, ktorí boli pokrstení až neskôr a už podl'a katolíckeho rítu, si dlhú dobu držali pohanskú predstavu, že moc dynastie pramení z plodnosti panovníka, čiže čím viac právoplatných mužských potomkov vládne po zomrelom panovníkovi, tým bude mat’ dynastia väčšiu moc. ${ }^{70} \mathrm{~V}$ každom prípade, či v divisio regni vidíme germánsky zvyk či pohanskú tradíciu, od Gregora Tourského vieme, že po smrti Chlodovika I. v roku 511 si už jeho synovia rozdelili krajinu medzi sebou nie podl'a závetu svojho otca, ale na základe ich vlastnej dohody. ${ }^{71}$ Divisio regni, čiže prax rozdelenia krajiny, prežívala d’alej aj v ríši Karolovcov. ${ }^{72}$ Avšak v porovnaní $s$ dobou Merovejovcov sa situácia natol'ko zmenila, že, počnúc dedičskoprávnym nariadením Karola Vel'kého z roku 806, sa delenie krajiny dialo v závete, alebo vo vopred určenej zmluve. ${ }^{73}$ Do 10 . storočia trvajúca, takmer normatívna prax rozdel'ovania krajiny však pre svoju povahu neprebiehala hladko. Bola zdrojom mnohých konfliktov. Typickými príkladmi sú prípady, ked' sa niektorý syn zosnulého otca usiloval nezákonne získat’ moc nad čast’ou krajiny. ${ }^{74}$ Ale odhliadnuc aj od spomínaných, nápadne protiprávnych prípadov, delenie moci sprevádzali neustále spory a nedorozumenia, v prvom rade medzi otcami a synmi. ${ }^{75}$ Prax divisio regni nakoniec zanikla na začiatku 10. storočia po nástupe saskej dynastie, ked' ju, odvolávajúc

\footnotetext{
${ }^{69}$ ERKENS, Franz-Reiner: Divisio legitima und unitas imperii. Teilungspraxis und Einheitsstreben in der Thronfolge in Frankenreich. In: Deutsches Archiv für Erforschung des Mittelalters 52. 1996, s. 423-485; KASTEN, B.: Königssöhne und Königsherrschaft, s. 9-10. ${ }^{70}$ GRAUS, František: Über die sogenannte germanische Treue. In: Historica 1. 1959, s. 71-121.

${ }^{71}$ Defuncto igitur Clodovecho regi, quttuor filii eius ... regnum eius accipiunt et inter se aequa lantia dividunt. KRUSCH, Bruno - LEVISON, Wilhelm (eds.): Gregorii Turonensis Opera. Libri Historiarum X, Lib. III. c. 1. MGH Scriptores Rerum Merovingicarum (d'alej len SRM) I/1. Hannover : Harrassowitz Verlag, 1951, s. 97.

${ }^{72}$ KASTEN, B.: Königssöhne und Königsherrschaft, s. 138-198.

${ }^{73} \mathrm{~V}$ súvislosti s cisárovým testamentom pozri BORETIUS, Alfred - KRAUSE, Victor (eds.): Capitularia regum Francorum. MGH Capitularia I. Hannover : Hahnsche Buchhandlung, 1883, s. 126-128, nr. 45. Pozri aj TRISCHLER, Matthias M.: Die „Divisio regnorum“ von 806 zwischen handschriftlicher Überlieferung und historiographischer Rezeption. In: Herrscher- und Fürstentestamente im westeuropäischen Mittelalter. Hg. von Brigitte Kasten, Köln - Weimar - Wien : Böhlau, 2008, s. 193-258.

${ }^{74}$ Chilpericus vero post patris funera thesaurus, qui in villa Brannacum ferant congregati, accepit et ad Francos utiliores petiit ipsusque muneribus mollitus sibi subdidit. Et mox Parisius ingreditur sedemque Childeberthi regis occupat; sed non diu ei a hoc licuit possedere; nam coniuncti fratres eius eum exinde repulerunt, et sic inter se hii quattuor, id est Chariberthus, Gunthramnus, Chilpericus atque Sigiberthus, divisionem legitimam faciunt. Gregorii Turonensis Opera. Libri Historiarum X, Lib. X. c. 22. MGH SRM I/1, s. 152-153.

${ }^{75}$ KASTEN, B.: Königssöhne und Königsherrschaft, s. 11-13.
} 
sa na jednotu ríše, úplne zakázali. ${ }^{76}$ Tak sa po úpadku karolovskej doby chápanie divisio regni prevzaté z Biblie rozšírilo o nový významový prvok. Biblické úslovie sa odvtedy stalo synonymom nesvornosti a rozporov v panovníckom rode a chaotickej vlády v krajine. ${ }^{77} \mathrm{~V}$ tomto význame ho spomína ešte aj preambula slávnej Zlatej buly Karola IV.78

Hoci necituje miesto v Biblii, predsa je možné sa odôvodnene domnievat', že aj 88. kapitola spomínanej kroniky chápala pojem divisio regni v zásade z dvoch pohl'adov. Jeden z nich sa týka vzniku král'ovského vojvodstva. Avšak sa zdá, že principiálne - hospodárske a teritoriálne - rozdelenie moci bolo len jednou stránkou posudzovania bojov o trón král'ov a vojvodov. Vzájomný vzt’ah dvoch bratov, král'ova prosba, sl'ub, záznam o nástupníctve nasvedčujú tomu, že kronikára karhajúceho Ondreja a Bela aspoň rovnako zaujímala discordia, vznik rozporu a hašterenia medzi príbuznými, teda samotné konflikty a tí l'udia, predovšetkým príbuzní, ktorí stáli proti sebe.

Rozprávacie pramene uchovávajúce dejiny vojvodstva v prvom rade poukazujú na vzájomné vzt’ahy účastníkov konfliktov a zachytávajú zmenu tohto vzt'ahu. Mnohovravným je v tomto ohl'ade výraz magna dilectio, nachádzajúci sa vo vyššie spomínanej 88. kronikárskej kapitole. Dilectio je v teologickom význame slova jednou z foriem pojmu lásky caritas, pocit’ovanej voči Bohu a blížnemu, a zároveň jednou zo zastávok na ceste vedúcej k nej. ${ }^{79}$ Už aj Alkuin učil, že perfecta caritas je najvyšším stupňom citov prechovávaných $\mathrm{k}$ Bohu a blížnemu. Aj z jeho listov vysvitá, že bez Krista niet dokonalej lásky. ${ }^{80}$ Dôkaz o tom, že pojem caritas mohol byt' súčast'ou dobového spoločenského zmýšlania a mohol mu byt' prisudzovaný rozhodujúci význam z pohl'adu vnútrorodinných

\footnotetext{
${ }^{76} \mathrm{~K}$ tomu pozri známu listinu Henricha I.: SICKEL, Theodor (ed.): Conradi I. Heinrici I. et Ottonis I. diplomata. MGH Diplomata I. Hannover : Hahnsche Buchhandlung, 1879 - 1884, s. 55-56, nr. 20; HLAWITSCHKA, Eduard: Zum Werden der Unteilbarkeit des mittealterlichen Deutschen Reiches. In: Stirps Regia. Forschungen zum Königtum und Führungsschichten im früheren Mittelalter. Ausgewählte Aufsätze. Festgabe zu seinem 60. Geburtstag. Hg. von Gertrud Thoma, Wolfgang Giese, Frankfurt am Main : Peter Lang, 1988, s. 247-259.

${ }^{77}$ Napríklad KURZE, Friedrich (ed.): Reginonis abbatis Prumiensis chronicon cum continuatione Treverensi. MGH SRG in usum scholarum separatim editi 50. Hannover : Hahnsche Buchhandlung, 1890, s. 129; HOLTZMANN, Robert (ed.): Thietmari Merseburgensis episcopi Chronicon. MGH SRG N. S. 9. München : Monumenta Germaniae Historica, 1996, s. 488-490.

${ }^{78}$ FRITZ, Wolfgang D. (ed.): Die Goldene Bulle Kaisers Karl IV. vom Jahre 1356. MGH Fontes Iuris Germanici Antiqui in usum scholarum separatim editi 11. Weimar : Böhlau, 1972, s. 44-45.

${ }^{79}$ Pozri EPP, V.: Amicitia. Zur Geschichte, s. 37-42.

${ }^{80}$ Caritas igitur, quam Deus praecepit, duplex esse debet: id est Dei et proximi. DÜMMLER, Ernst (ed.): Alcuini sive Albini epistolae. MGH Epistolae 4. Berlin : Weidmann, 1895, s. 95 , nr. 51.
} 
konfliktov, poskytuje scéna s Karitas z Hartvikovej legendy. ${ }^{81}$ Henrik Marczali považoval túto pasáž za neskorú interpoláciu, 82 ale Józsefovi Gericsovi sa podarilo dokázat', že text bol už v pôvodnom znení legendy. ${ }^{83}$ Avšak Emma Bartoniek úlohu Karitas v legende poňala alegoricky a jej výskyt $v$ texte ako prejav vôle nižších spoločenských vrstiev. ${ }^{84}$ Voči týmto konštatovaniam už Flórián Mátyás podotkol, že Bernoldova kronika, ${ }^{85}$ poskytujúca správy o Šalamúnovi, dodáva inú chronológiu k oslobodeniu král'a, ${ }^{86}$ čo viedlo Gyulu Kristóa, odmietajúceho názory Emmy Bartoniek, $\mathrm{k}$ tomu, aby vo výjave videl skôr otázku legitimity a idoneity obdobia Kolomana. ${ }^{87}$ Podl'a našej mienky je výjav alegorický a časti vzt’ahujúce sa na Karitas jednoznačne odkazujú na zmierenie a nutnost' obnovy pôvodného vzt'ahu k Bohu a $\mathrm{k}$ nášmu blížnemu. Je teda pravdepodobné a opät' to pripomíname, že v čase rozkvetu konfliktov medzi Arpádovcami, počas sporu Kolomana a Álmoša, prisudzovali zvláštny význam kvalite osobného vzt'ahu spoluvládnucich bratov.

Otázku vojvodstva je teda vhodné skúmat' v závislosti od vývoja vzt'ahu medzi príbuznými, pretože autori prameňov pripisovali týmto vzt'ahom vel'ký význam. Na tomto mieste je potrebné odhliadnut' od podrobného, všetko zahŕňajúceho vykreslenia tohto systému vzt’ahov. ${ }^{88}$ Môžeme sa však domnievat', že aj skutočný význam divisio regni, vzt'ahujúci sa na rozdelenie krajiny a moci, závisel najmä od postoja účastníkov sporov o trón a ich vzájomných vzt'ahov. Chcel by som, paralelne s

\footnotetext{
${ }^{81}$ quadam inclusa iuxta ecclesiam Sancti Salvatoris in Bucan Sumliu, nomine Karitas, cuius vite percelebris tunc temporis opinio ferebatur, revelatione sibi celitus facta, regi mandavit eos incassum niti, non posse sanctum regis transferri pignora, donec Salomon a carcerali absoluto custodia, libera intulgentia preberetur. BARTONIEK, Emma (ed.): Legenda Sancti Stephani regis maior et minor, atque legenda ab Hartvico episcopo conscripta. SRH II, s. 434.

${ }^{82}$ MARCZALI, H.: Magyarország története az Árpádok korában, s. 134.

${ }^{83}$ GERICS, J.: Legkorábbi gesta-szerkesztéseink, s. 94.

${ }^{84}$ BARTONIEK, E.: A magyar királyválasztási jog a középkorban, s. 368.

${ }^{85}$ ROBINSON, Ian S. (ed.): Die Chroniken Bertholds von Reichenau und Bernolds von Konstanz 1054 - 1100. MGH SRG N. S. 14. Hannover : Hahnsche Buchhandlung, 2003, s. 465.

${ }^{86}$ MÁTYÁS, Flórián: Chronológiai megállapítások hazánk XI. és XII. századi történetéhez. Értekezések a történelmi tudományok köréből 19. Budapest : Magyar Tudományos Akadémia, 1899, s. 18.

${ }^{87}$ KRISTÓ, Gyula: Legitimitás és idoneitás (Adalékok Árpád-kori eszmetörténetünkhöz). In: Századok. roč. 108, č. 3, 1974, s. 594.

${ }^{88}$ Predovšetkým ide o problém prísah a ich porušenia, ako aj otázku podrobenia sa. K podrobeniu/podriadeniu sa pozri ALTHOFF, Gerd: Königsherrschaft und Konfliktbewältigung im 10 - 11. Jh. In: Frühmittelalterliche Studien 23. 1989, s. 265-290. K uhorským pomerom pozri BAGI, Dániel: Egy barátság vége. Álmos 1106. évi alávetése és az Árpádok korai dinasztikus konfliktusai. In: Századok roč. 147, č. 2, 2013, s. 381-409.
} 
Nové možnosti prístupu k výskumu dejín vojvodstva v 11. storočí

podobnými príkladmi z dejín Piastovcov a Přemyslovcov, pojednat' o čase vzniku vojvodstva a o kompetenciách vojvodskej moci.

\section{III.}

Najprv sa pozrime na otázku, kedy vzniklo vojvodstvo.

Pri krátkom pohl'ade spät' na modely vojvodstva Györgya Györffyho a Gyulu Kristóa je potrebné krátko poznamenat', že ani neskorší výskum nedokázal dospiet' ku konsenzu v otázke, kedy král'ovské vojvodstvo vzniklo. Niektorí historici odvodzovali jeho počiatky z dôb zaujatia vlasti, ${ }^{89}$ avšak iní, oživujúc už skôr skoncipované názory v mad'arskej historiografii, ${ }^{90}$ kládli čas jeho vytvorenia do obdobia svätého Štefana. ${ }^{91}$ Naproti nim nebolo a nie je málo tých, ktorí, nezávisle od stanoviska Gyulu Kristóa alebo ho prijímajúc, datujú počiatky vojvodstva do obdobia Ondreja I. ${ }^{92} \mathrm{~V}$ tomto ohl'ade zaujali akési spoločné stanovisko Ákos Timon, Pál Engel a Márta Font. Podl'a Timona a Engela je vojvodstvo z obdobia svätého Štefana, ${ }^{93}$ prípadne ho môžeme sledovat' už v 10. storočí, ${ }^{94}$ avšak skutočnými mocenskými funkciami a jasnými, hmatatel'nými kontúrami disponuje len od čias Ondreja I. a Bela. Podl'a Márty Font neboli teórie Györffyho a Kristóa, napriek zdaniu, od seba vzdialené. Ani ona nepovažovala za nemožné, aby korene rozdelenia krajiny z doby Ondreja I. siahali do skorších čias, a že Ondrej iba obnovil už predtým existujúcu tradíciu, hoci zároveň konštatovala, že to nie je možné potvrdit' prameňom..$^{95}$ Napokon je tu potrebné spomenút' stanovisko Attilu Zsoldosa. Podl'a neho siaha história majetkového komplexu vojvodov, podobne ako majetkového komplexu král'ovien, do obdobia svätého Štefana. Nachádzalo sa po celom území krajiny a patrilo členom rodiny nosiacim titul dux. Samotné pravidelné delenia krajiny začali v polovici

\footnotetext{
${ }^{89}$ HECKENAST, Gusztáv: Fejedelmi (királyi) szolgálónépek a korai Árpád-korban. Értekezések a történeti tudományok köréből. Új sorozat 53. Budapest : Akadémiai Kiadó, 1970, s. 38. ${ }_{90}^{90}$ MARCZALI, H.: Magyarország története az Árpádok korában, s. 59; RUGONFALVI KISS, I.: Trónbetöltés és ducatus, s. 746.

${ }^{91}$ SIMON, Péter V.: A Nibelungének magyar vonatkozásai. In: Századok. roč. 112, č. 2, 1978, s. 322; TÖRÖK, József: A tizenegyedik század magyar egyháztörténete. Keresztény századok. Budapest : Mikes Kiadó, 2002, s. 83.

${ }^{2}$ SZÉKELY, György: Magyarország története a honfoglalástól Mohácsig. In: Magyarország története I. Szerk. Molnár Erik, Budapest : Gondolat, 1971, s. 57; KOSZTA, László: A nyitrai püspökség létrejötte (Nyitra egyháztörténete a 9-13. században). In: Századok. roč. 143, č. 2, 2009, s. 257-318.

93 TIMON, Á.: Magyar alkotmány- és jogtörténet, s. 115.

${ }^{94}$ ENGEL, Pál: The Realm of St. Stephen. A History of Medieval Hungary 895 - 1526. London - New York : I. B. Tauris, 2001, s. 30-31.

${ }^{95}$ FONT, Márta: A középkori Magyar Királyság. Az Árpád-házi királyok kora 970 - 1301. In: Magyarország története. Szerk. Romsics Ignác, Budapest : Akadémiai Kiadó, 2007, s. 68.
} 


\section{Dániel Bagi}

11. storočia (hoci delenie za Gejzu a Kopáňa môže byt' považované za ich predobraz). Predsa len, počnúc od rozdelenia krajiny Ondrejom I. a Belom, vojvodovia získali väčšiu moc, lebo okrem im patriacim majetkom nadobudli moc aj nad jednou tretinou krajiny. ${ }^{96}$ Ohl'adom počiatkov vojvodstva je hned' nápadné, že v 88. kapitole kronikárskej kompozície hrá dôležitú úlohu konsenzus - Ondrej a Belo sa dohodli na rozdelení krajiny zo slobodnej vôle. Kronika to vyjadruje frázou habito consilio. V spojitosti s týmto výrazom zaujal Gyula Kristó stanovisko, podl'a ktorého bolo do rozdelenia krajiny potrebné vtiahnut' aj král'ovskú radu pozostávajúcu z vel'možov zaujímajúcich sa o partikularizmus. ${ }^{97}$ Niet pochýb, že vel'možov mohla zaujímat' dohoda vznikajúca v rámci dynastie, nanajvýš je možné poznamenat' tol'ko, že samotný dohovor sa týkal členov rodiny. Dohoda bola v podobných prípadoch nutná aj za vlády merovejskej a karolovskej dynastie. Jej absencia znemožnila rozdelenie moci. Bolo to tak po smrti král'a Chlodovika I. v roku $511^{98}$ alebo po smrti král'a Chlotara I. v roku 561. U posledného zmieneného vysvitlo aj to, že jeho deti, pochádzajúce z rozličných manželstiev, si dovtedy nevedeli legálne krajinu rozdelit', kým sa, po neúspešnej vzbure Chilpericha, ${ }^{99}$ navzájom nedohodli. ${ }^{100}$ Podobne ako pri dohode v rodine, bol konsenzus potrebný aj na prijatie závetu Karola Vel'kého z roku 806, v ktorom cisár, ovplyvňujúc aj osudy budúcich generácií, vopred rozdelil krajinu medzi svojich potomkov. Udalost' poznáme $\mathrm{z}$ dvoch prameňov. Z Annales regni Francorum vieme, že závet bol vytvorený so zámerom zachovania mieru. Z príbehu sa ukazuje aj to, že obsah závetu musel byt' známy v širšom okruhu, pretože naň prisahali aj vel'moži. ${ }^{101}$ A presný obsah samotného

\footnotetext{
${ }^{96}$ ZSOLDOS, A.: Az Árpádok és alattvalóik, s. 77.

${ }^{97}$ KRISTÓ, Gy.: A XI. századi hercegség, s. 47.

98 Defuncto igitur Chlodovecho regi, quattuor filii eius, id est Theudoricus, Chlodomeris, Childeberthus atque Chlothacharius, regnum eius accipiunt et inter se aequa lantia dividunt. Gregorii Turonensis Opera. Libri Historiarum X, Lib. III. c. 1. MGH SRM I/1, s. 97.

${ }^{99}$ Chilpericus vero post patris funera thesaurus, qui in villa Brannacum ferant congregati, accepit et ad Francos utiliores petiit ipsusque muneribus mollitus sibi subdidit. Et mox Parisius ingreditur sedemque Childeberthi regis occupat. Gregorii Turonensis Opera. Libri Historiarum X, Lib. III. c. 22. MGH SRM I/1, s. 152-153.

100 sed non diu ei a hoc licuit possedere; nam coniuncti fratres eius eum exinde repulerunt, et sic inter se hii e quattuor, id est Chariberthus, Gunthramnus, Chilpericus atque Sigiberthus, divisionem legitimam faciunt. Gregorii Turonensis Opera. Libri Historiarum X, Lib. III. c. 22. MGH SRM I/1, s. 153.

${ }^{101}$ Illisque absolutis conventum habuit imperator cum primoribus et optimatibus Francorum de pace constituenda et conservanda inter filios suos et divisione regni facienda in tres partes, ut sciret unusquisque illorum, quam partem tueri et regere debuisset, si superstes illi eveniret. De hac partitione et testamentum factum et iureiurando ab optimatibus Francorum confirmatum, et constitutiones pacis conservandae causa factae, atque haec omnia litteris mandata sunt et Leoni papae, ut his sua manu subscriberet, per Einhardum missa. Quibus pontifex lectis et adsensum praebuit et propria manu subscripsit. PERTZ, Georg Heinrich
} 
závetu, našt’astie, zachovali kapituláre karolovskej doby. Tak je možné presne vediet', že Karol Vel'ký sa v závete rozhodoval o konkrétnych územiach, ktorým uviedol aj presné hranice a dôležitejšie strediská. Do závetu zahrnul nielen svoje deti, ale aj ich potomkov, zakladajúc tým svojrázny dedičský poriadok v karolovskej ríši. ${ }^{102} \mathrm{Aj}$ rodinné delenia saskej dynastie si vyžadovali konsenzus. Henrich I. vystavil v roku 929 listinu, ktorou sa postaral o rodinné majetky, ktoré zanechal svojej manželke. ${ }^{103}$ Skorší výskum videl v listine akýsi raný rodinnoprávny zákon (Hausordnung), ktorý zároveň upravoval aj nástupníctvo. Neskôr sa však podarilo dokázat', že Ota mohol jeho otec určit' k vláde už ovel'a skôr, čo vylučuje možnost', aby toto bol dôvod vydania listiny. ${ }^{104}$ Listina hovorí skôr o urovnaní rodinných majetkov a jej text nespomína ani Thankmara, Henrichovho syna z prvého manželstva, a ani Otovho brata Henricha. Máme dôkazy, že dotyční zavrhovali nariadenia dokumentu. Oto I. ihned' po nástupe k moci zopakoval príkaz svojho otca a dal svojej matke k dispozícii Quedlinburg so všetkým jeho príslušenstvom a práva na tento hrad zabezpečil aj svojim potomkom. ${ }^{105}$ Je pravdepodobné, že so vzniknutou situáciou nemohol byt' spokojný ani Thankmar, ani Henrich. Od Widukinda vieme, že sa Thankmar vel'mi urazil, ked' nemohol získat' uvol'nenú Merseburskú marku, ale Oto I. ju daroval, hoci Thankmar chcel majetok získat' z dôvodu pokrvného príbuzenstva. ${ }^{106}$ Henrich si zas viacerými vojnami vynútil, aby dostal Lotrinsko. Tento príklad z dejín saskej dynastie je dôkazom toho, že majetkové delenia, z ktorých vynechali rodinných príslušníkov, viedli k sporom, ktoré sa dali urovnat' iba obnovením konsenzu. Ďalším príkladom je spor Knuta Vel'kého s bratom Haralda Svenssona, ktorý po smrti ich otca zdedil dánsky trón. Detailnú správu o spore podávajú Skutky král'a Knuta (Cnutonis regis gesta). Knut žiadal svojho brata, aby sa s ním podelil o Dánsko, považované za dedičstvo, čo

(ed.): Annales Regni Francorum. Inde ab a. 741 usque ad a. 821., ad a. 806. MGH SRG 6. Hannover : Hahnsche Buchhandlung, 1895, s. 121.

102 Úplný text závetu pozri Capitularia regum Francorum. MGH Capitularia I, s. 126, nr. 45. 103 placuit etiam nobis domum nostram deo opitulante ordinaliter disponere. Quapropter legali moderatione, asstantibus a fidelibus nostris; cum consensu et astipulatione filii nostri Ottonis et episcoporum procerumque et comitum peticione dulcissimae coniugi nostrae Mahthildae potestativa manu tradimus et donamus quicquid propriae hereditatis in praesenti videre habemur in locis infra nominatis - haec enim sunt: Quitilingaburg Palidi, Nordhuse, Gronaa, Tuterstetie - cum civitatibus et omnibus ad praedicta loca pertinentibus in ius proprium concessimus. Conradi I. Heinrici I. et Ottonis I. diplomata. MGH Diplomata I, s. 56, nr. 20.

${ }^{104}$ LAUDAGE, Johannes: Otto der Große. Stuttgart : Pustet, 2005, s. 105.

${ }^{105}$ Conradi I. Heinrici I. et Ottonis I. diplomata. MGH Diplomata I, s. 90, nr. 1.

106 HIRSCH, Paul - LOHMANN, Hans-Eberhard (eds.): Widukindi monachi Corbeiensis Rerum gestarum Saxonicarum libri III, Lib. II. c. 9. MGH SRG 60. Hannover : Hahnsche Buchhandlung, 1939, s. 70. 


\section{Dániel Bagi}

Harald rozhodne odmietol. ${ }^{107}$ Vyjednávanie, ktoré pravdepodobne prebiehalo formou rokovania, ${ }^{108}$ skončilo bezvýsledne. Gesta boli napísané už s vedomím, že kvôli predčasnej smrti Haralda sa krajina napokon dostala do rúk Knuta. Podl'a neznámeho historika Harald a Knut neuzavreli dohodu a preto sa nedokázali podelit' o otcovské dedičstvo a moc. S podobnou situáciou sa stretávame v Kyjevskej Rusi. Jaroslav Múdry rozdelil v závete svoju ríšu medzi svojich synov. Synovia boli teda nútení dospiet' ku konsenzu o otcovskom dedičstve. ${ }^{109}$ To je zaujímavé už len preto, lebo v tomto prípade karolovsko-otonskú organizáciu moci nemôžeme považovat' za vzor.

Viacero generácií pol'ských a českých (československých) vedcov sa pokúsilo nájst' počiatky dynastického rozdelenia moci v 10. alebo aj 9. storočí, avšak je vel'avravné, že všetky najstaršie, z prameňov známe pokusy Piastovcov a Přemyslovcov o rozdelenie krajiny sa objavujú až v druhej polovici 11. storočia a myslitel'né boli len v konsenzuálnej forme. U Piastovcov sa prvá takáto príležitost' naskytla okolo roku 1097. Knieža Vladislav Herman mal z dvoch manželstiev dvoch synov. Nedokázali sa dohodnút' na spravovaní krajiny a ešte za svojho života podelil krajinu medzi nich a seba. ${ }^{110}$ Neskôr svoje nariadenie spresnil. ${ }^{111} 0$ rozdelení

\footnotetext{
${ }^{107}$ Est quidem quod mihi facies, si non gloriae mae invides, ut dividas mecum regnum Danorum, meam scilicet hereditatem quam solus tenes ... Haroldus rex audito quod noluit, his fratrem verbis excepit: Gaudeo, frater, de tuo adventu, habeoque gratias tibi quod me visitasti, sed est grave auditu quod loqueris de divisione regni. Hereditatem quam mihi pater te laudante tradidit, guberno, tu vero hac maiorem amisisti doleo, teque iuvare paratus, regnum meum partiri non sustinebo. PERTZ, Georg Heinrich (ed.): Cnutonis regis Gesta sive encomium Emmae reginae auctore monacho sancti Bertini, Lib. II. c. 2. MGH SRG 22. Hannover : Hahnsche Buchhandlung, 1865, s. 11-12.

108 Talibus aliisque diversis sermonibus colloquentes, convivisque regalibus convivantes, aliquanto tempore simul manserunt. Cnutonis regis Gesta sive encomium Emmae reginae auctore monacho sancti Bertini, Lib. II. c. 2. MGH SRG 22, s. 12.

109 DIMITRIEV, Lev Alexandrovič - LICHAČEV, Dmitrij Sergejevič (eds.): Povest' vremennych let. Pamiatniki literatury Drevnej Rusi XI - načalo XII veka. Moskva : Chudo-žestvennaja literatura, 1978, s. 175-176. Pozri FONT, Márta: Oroszország, Ukrajna, Rusz. Budapest : Balassi, 1998, s. 45.

110 Unde pater. mescio quid suspicans, confestim inter eos regnum divisit, sed de manu tamen sua sedes regni principales non dimisit. MALECZYŃSKI, Karol (ed.): Galli Anonymi chronicae et gesta ducum sive principum Polonorum, Lib. II. c. 7. In: Monumenta Poloniae Historica. (d'alej len MPH) Nova series 2. Kraków : Polska Akademia Umiejętności, 1952, s. 77. Mad'arsky pozri BAGI, Dániel (ed.): Gall Névtelen: A lengyel fejedelmek avagy hercegek krónikája és tettei. (d’alej len Gall Névtelen) Fordította, bevezető tanulmánnyal és jegyzetekkel ellátta Bagi Dániel. A verseket fordította Jankovits László. Budapest : Argumentum, 2007, s. 168.

${ }^{111}$ Post obitum quidam meum Zbigneus cum hoc, quod habet, Mazouiam simul habeat, Bolezlauus vero, legitimus filius meus, in Wratislaw et in Cracou et in Sandomir sedes regni principales obtineat. Galli Anonymi chronicae et gesta ducum sive principum Polonorum, Lib. II. c. 8. MPH N. S. 2, s. 78; Gall Névtelen, s. 169.
} 
Nové možnosti prístupu k výskumu dejín vojvodstva v 11. storočí

krajiny medzi Vladislava Hermana a jeho synov vie (datované len k úmrtiu kniežat'a v roku 1102) Kosmas ${ }^{112}$ a pravdepodobne vd'aka Kosmasovi aj kronika Analistu Saxa napísaná v polovici 12 . storočia. ${ }^{113}$ Kosmova kronika zachovala takzvaný závet českého kniežat’a Břetislava I. z roku 1055. V ňom sa umierajúci knieža rozhodol o spôsobe nástupníctva. ${ }^{114}$ Podl'a Kosmovho opisu Břetislav vyhradil na delenie Moravu. Podstatným prvkom tohoto delenia bola dohoda medzi členmi rodiny.

Domnievam sa, že existencia konsenzu, prípadne jeho absencia, je kl'účom k času vzniku stredo-východoeurópskych vojvodstiev. K dohode medzi Ondrejom a Belom sa vracali ako ich synovia, tak aj Belovi vnuci Koloman a Álmoš, prípadne pri občasnom oživení spoločnej vlády boli potrebné nové dohody založené na konsenze. Dohodu Piastovcov z roku 1097, zrejme založenú na dohovore Hermana a jeho synov, bolo náročné presadit' už po smrti Hermana. Zbigniew a Boleslav sa pohádali nad nepochovaným telom ich otca o rozdelení krajiny a pokladnice. Len vd'aka sprostredkovaniu hniezdnenskeho arcibiskupa boli ochotní dodržat' to, čo sl'úbili ešte za života zosnulého otca. ${ }^{115}$ Aj súčasníci videli zhoršenie vzt’ahu oboch bratov. Zdá sa, že konsenzus hral hlavnú úlohu aj v štatúte regulujúcom postavenie moravských Přemyslovcov. Neskoršie dianie

\footnotetext{
${ }^{112}$ Anno dominice incarnationis MCII. Wladizlaus dux Polonie habens duos filios, unum de concubina progenitum, nomine Izbigneu, alterum ex Iuditha Wratizlai regis filia editum, nomine Bolezlaum, hos inter suum regnum dividit per medium. Cosmae Pragensis Chronica Boemorum, Lib. II. c. 16. MGH SRG N. S. 2, s. 178-179.

${ }^{113}$ His temporibus obiit Uuladizlaus dux Polonie habens duos filios, unum de concubina dictum Spigneu, alterum ex Iudhita sorore ducis Boriuoy nomine Bolezlaum, quibus regnum suum divisit per medium. NASS, Klaus (ed.): Annalista Saxo. MGH Scriptores (d'alej len SS) 37. Hannover : Hahnsche Buchhandlung, 2006, s. 311.

${ }^{114}$ Quia me mea fata vocant et atra mors iam pre oculis volat, volo vobis assignare et vestre fidei commendare, qui post me debeat rem publicam gubernare. Vos scitis, quia nostra principalis genealogia partim sterilitate partim pereuntibus in inmatura etate me usque ad unum fuit redacta. Nunc autem, ut ipsi cernitis, sunt mihi a Deo dati quinque nati, inter quos dividere regnum Boemie non videtur mihi esse utile, quia omne regnum in se ipsum divisum desolabitur. Quia vero ab origine mundi et ab initio Romani imperii et usque ad hec tempora fuerit gratia rara, testantur nobisexempla rata. Nam Cain et Abel, Romulus et Remus et mei attavi Bolezlaus et sanctus Wencezlaus si spectes quid fecerint fratres bini, quid facturi sunt quini? Hos ergo quanto potiores ac potentiores intueor, tanto mente presaga peiora augurior. Heu mens semper pavida genitorum de incertis fatis natorum. Unde previdendum est, ne post mea fata aliqua inter eos oriatur discordia propter obtinenda regni gubernacula. Quade re rogo vos per Dominum et obtestor fidei vestre persacramentum, quatinus inter meos natos sive nepotes semper maior natu summum ius et solium obtineat inprincipatu omnesque fratres sui sive, qui sunt orti herili de tribu, sint sub eius dominatu. Credite mihi, nisi monarchos hunc regat ducatum, vobis principibus ad iugulum, populo ad magnum deveniet damnum. Cosmae Pragensis Chronica Boemorum, Lib. II. c. 13. MGH SRG N. S. 2, s. 102. ${ }^{115}$ sed divina gratia inspirante et archiepiscopo sene fideli mediante, preceptum viventis in presencia mortui tenuerunt. Galli Anonymi chronicae et gesta ducum sive principum Polonorum, Lib. II. c. 21. MPH N. S. 2, s. 107.
} 


\section{Dániel Bagi}

dokazuje, že v priebehu 11. storočia sa naň v konfliktných situáciách aj viackrát odvolávali ako na dohovor v rámci rodiny.

Ak do stredobodu staviame existenciu alebo absenciu dohovoru, tak pri návrate k otázke, či vojvodstvo Arpádovcov z 11. storočia má staršie korene alebo predobrazy, môžeme konštatovat' nasledovné. Odhliadnut' môžeme od titulu dux Ruizorum král'oviča Imricha, za ktorým sa pravdepodobne nachádza poverenie od otca a $\mathrm{k}$ tomu prislúchajúce majetky. ${ }^{116}$ Henrich III. počas svojej výpravy proti Samuelovi Abovi v roku 1042 obsadil devät' uhorských hradov. Z Henrichovej vôle sa vlády nad obsadeným územím ujal niektorý fratruelus svätého Štefana. Pri dosadení Štefanovho príbuzného celkom určite chýbal konsenzus. ${ }^{117}$ Výskum dodnes nedokázal dospiet' ku konsenzu v otázke, či osobou vybranou Henrichom III. bol Ondrej, ${ }^{118}$ Belo ${ }^{119}$ alebo niekto iný. ${ }^{120}$ Novšia slovenská historiografia však využíva tento príbeh v prvom rade na potvrdenie toho, že Nitrianske vojvodstvo existovalo už skôr. Nech už osobou podporovanou Henrichom III. bol ktokol'vek, za svoje krátke panovanie mohol vd'ačit' len rímsko-nemeckému panovníkovi. Tento prípad vôbec nebol ojedinelý. Od Wipa vieme, že Konrád II. si rovnako počínal v spore o trón medzi Meškom II. a jeho bratmi. ${ }^{121}$ A taktiež on už o rok skôr umožnil, aby sa český knieža Oldřich mohol vrátit’ z vyhnanstva a následne rozdelil Čechy medzi ním a Jaromírom. ${ }^{122}$ Zasahovanie ríše do záležitostí

\footnotetext{
${ }^{116}$ ZSOLDOS, Attila: Szent Imre herceg. In: Szent Imre 1000 éve. Tanulmányok Szent Imre tiszteletére, születésének ezredik évfordulója alkalmából. Szerk. Kerny Terézia, Székesfehérvár : Székesfehérvári Egyházmegyei Múzeum, 2007, s. 20-23.

${ }^{117}$ Novem ibi civitates rex deditione cepit, quas rogatu Bratislaui et consensu incolarum fratrueli Stephani regis, qui cum eadem duce advenerat, dedit. OEFELE, Edmundus Frh. v. (ed.): Annales Altahenses Maiores, ad a. 1042. MGH SRG 4. Hannover : Hahnsche Buchhandlung, 1979, s. 32.

${ }^{118}$ PAULER, Gy.: A magyar nemzet története I, s. 82-83; JASIŃSKI, Kazimierz: Rodowód pierwszych Piastów. Poznań : Poznańskie Towarzystwo Przyjaciół Nauk, 2004, s. 145.

${ }^{119}$ SZÉKELY, György - BARTHA, Antal (Szerk.): Magyarország története. Előzmények és magyar történet 1242-ig I/1. Budapest : Akadémiai Kiadó, 1984, s. 839-840; VARGA, Gábor: Ungarn und das Reich vom 10. bis zum 13. Jahrhundert. Das Herrscherhaus der Árpáden zwischen Anlehnung und Emanzipation. München : Ungarisches Institut, 2003, s. 106.

${ }^{120}$ STEINHÜBEL, Ján: Nitrianske kniežatstvo: počiatky stredovekého Slovenska. Rozprávanie o dejinách nášho územia a okolitých krajín od st'ahovania národov do začiatku 12. storočia. Bratislava : Vydavatel'stvo Veda - Vydavatel'stvo Rak, 2004, s. 258-259.

${ }^{121}$ Caesar divisa provincia Bolanorum in tres partes Misiconem fecit tetrarcham, reliquas duas duobus aliis commendavit. BRESSLAU, Harry (ed.): Wiponis Opera, c. 29. MGH SRG 61. Hannover - Leipzig : Hahnsche Buchhandlung, 1915, s. 49.

122 Ubi Odalricus Boemiorum dux obtentu reginae nec non et procerum de exilio rediit, et ducatus sui medietatem, fratre suo Germiro alteram partem retinente, suscepit. PERTZ, Georg Heinrich (ed.): Annales Magdeburgenses, ad a. 1031. MGH SS 16. Hannover : Hahnsche Buchhandlung, 1859, s. 170.
} 
dynastií vládnucich v okolitých krajinách pokračovalo aj neskôr a to nielen v stredovýchodnej Európe. Henrich III. podobnými spôsobmi usporadúval spory medzi panovníkmi Dolného a Horného Lotrinska. ${ }^{123}$ Ďalej je pochybné, či je možné považovat' vystupovanie Kopáňa za predobraz vojvodstva. V Čechách bol na konci 10. storočia jeden podobný prípad, ked' české knieža Boleslav II. obsadil územia Slavníkovcov a rodinu až na pár výnimiek vyvraždil. ${ }^{124}$ Starší výskum považoval Slavníkovcov za kniežací rod konkurujúci Přemyslovcom a poukázal na to, že je t’ažké sa rozhodnút', či to bol spor dvoch osobitných kmeňov, alebo dvoch rodov v rámci jedného kmeňa. ${ }^{125}$ Avšak novšie výskumy preukázali, že boli príbuznými v rámci přemyslovskej dynastie. Navyše možno predpokladat', že kvôli svojej pozícii v rodine získali ešte v čase kniežat’a Boleslava I. (Ukrutného) tie majetky, ktoré potom v roku 995 stratili. ${ }^{126}$ Presné okolnosti ich tragédie nepoznáme. Svätovojtešská legenda zachytávajúca správy o tejto udalosti, hoci vznikla v úplnom závere 10. storočia, prípadne na začiatku 11. storočia, bola nevyhnutne zaujatá. O Slavníkovcoch sa nedozvedáme objektívne informácie ani z Kosmovej kroniky zo začiatku 12. storočia. Kronikár sa usiloval posudzovat' činy prvej generácie Přemyslovcov natol'ko opatrne, že vyvraždenie Slavníkovcov pripísal na účet comesov. Avšak aj keby sme Slavníka zbavili trópmi vyjadrenej úcty, ktorá mu ako otcovi svätého mučeníka náleží, aj tak by Slavník, od ktorého pochádza pomenovanie rodiny, nemohol disponovat' nevýznamnou mocou v Čechách v druhej polovici 10. storočia. ${ }^{127}$ Avšak ním vlastnené územia mohli byt' skôr súkromnými majetkami, náležiacimi rozličným vetvám rodiny, než akési kniežatstvo disponujúce samostatnou mocou. A tak môžeme, opierajúc sa o túto analógiu, opatrne predpokladat', že Kopáňom ovládané územie nazývané vojvodstvom sa môže považovat' za predobraz vojvodstva vznikajúceho v polovici 11. storočia

\footnotetext{
${ }^{123}$ Annales Altahenses Maiores, ad a. 1046. MGH SRG 4, s. 41; WEINFURTER, Stefan: Das Jahrhundert der Salier (1024 - 1125). Stuttgart: Thorbecke, 2004, s. 107.

${ }^{124}$ Et quia tunc temporis dux non erat sue potestatis, sed comitum, comites versi in Dei odium, patrum iniquorum pessimi filii, valde malum operabantur facinus et iniquum. Nam sub quadam festiva die furtim irrumpunt urbem Lubic in qua fratres sancti Adalberti ... assistebant sacris missarum sollempniis festa celebrarent. At illi ceu lupi immanes urbis menia irrumpentes ... quatuor fratribus sancti Adalberti cum omni prole ante ipsum altare decollatis urbem comburunt. Cosmae Pragensis Chronica Boemorum, Lib. I. c. 29. MGH SRG N. S. 2, s. 53.

125 FONT, Márta (Szerk.): Dinasztia, hatalom, egyház. Régiók formálódása Európa közepén 900 - 1453. Pécs : Pécsi Tudományegyetem, 2009, s. 90.

126 TŘEŠTíK, D.: Počátky Přemyslovcủ, s. 89. Pozri ŽEMLIČKA, Josef: Čechy v době knížecí (1034 - 1198). Praha : Nakladatelství Lidové noviny, 1997, s. 40.

127 erat vir Zlaunic nomine, potens in honore et divitiis ... vir magnus inter cunctos eius terre habitatores. KARWASIŃSKA, Jadwiga (ed.): Sancti Adalberti Pragensis episcopi et martyris Vita Prior, c. 1. MPH N. S. 4/1. Warszawa : Państwowe Wydawnictwo Naukowe, 1962, s. 4.
} 


\section{Dániel Bagi}

nanajvýš z pohl'adu sporov o trón, v žiadnom prípade z pohl'adu rozdelenia krajiny na základe konsenzu.

Je teda pravdepodobné, že počiatky vojvodstva nie je možné datovat' pred dohodu Ondreja I. a Bela, ku ktorej sa vracali aj ich potomkovia, v rokoch 1063 - 1064 Šalamún a Gejza a okolo roku 1095 Koloman a Álmoš. To znamená, že rozdelenia krajiny, nech mali akýkol'vek územný rozsah, záviseli v prvom rade od vzt'ahu rodinných príslušníkov a konsenzu medzi nimi.

Ak chceme poznat' rozsah vojvodstva a jeho funkciu, treba postavit' do centra pozornosti dohodu členov rodiny a vzt'ahy medzi nimi. Pozoruhodné je, že ani 88. kronikárska kapitola, ani kronikárske správy o neskoršej obnove vojvodstva presne neprezrádzajú, aké majetky sa dostávali do vlastníctva vojvodov. V súvislosti s obnovami vojvodstva v 11. storočí sa v prípade Gejzu dozvedáme len tol'ko, že ho nahovorili, nech prijme vojvodstvo a vojvodskú moc, ktorú mal už jeho otec ${ }^{128}$ a Koloman odovzdal vojvodstvo svojmu bratovi $\mathrm{v}$ jeho celistvosti (plenarie). ${ }^{129}$ Ked'že pramene nespomínajú, na ktorých konkrétnych územiach sa Ondrej a Belo dohodli, naša historiografia, na základe údajov z kroník a iných prameňov, viažucich sa k miestam pobytu a činnosti vojvodov, sa usilovala nájst' hlavné strediská vojvodstva a zistit', kde v Karpatskej kotline sa vojvodstvo nachádzalo, ktoré územia zahŕňalo, a z kol'kých osobitných častí pozostávalo. Počas pokusov o jeho rekonštrukciu, ktoré sa vzt'ahovali na územný rozsah a geografické umiestnenie král'ovského vojvodstva a na určenie počtu vojvodstiev, sa od 19. storočia zrodilo mnoho navzájom si odporujúcich hypotéz.

Staršia mad'arská historiografia síce predstavovala územne odlišné modely, avšak vo vojvodstve 11 . storočia videla jedno súvislé územie. ${ }^{130}$ To dnes prijíma už len slovenská medievistika. ${ }^{131}$ Povojnová historiografia viazala vojvodstvo na dve alebo tri strediská. György Györffy, ako sme už spomenuli, rátal s tromi (Bihar, Nitra, hrad Krašov) a Gyula Kristó s dvomi (Bihar, Nitra). ${ }^{132} \mathrm{~V}$ podobnom duchu zaujali stanovisko Márta Font, László Koszta a Attila Zsoldos, ktorí sa domnievali, že král'ovské vojvodstvo mohlo pozostávat' z dvoch väčších blokov, ktoré

\footnotetext{
${ }^{128}$ Chronici Hungarici compositio saeculi XIV., c. 97. SRH I, s. 362.

${ }^{129}$ Chronici Hungarici compositio saeculi XIV., c. 142. SRH I, s. 420.

${ }^{130}$ PAULER, Gy.: A magyar nemzet története I, s. 96-97; KARÁCSONYI, J.: A magyar nemzet áttérése, s. 171; HÓMAN, B. - SZEKFÜ, Gy.: Magyar történet I, s. 258; RUGONFALVI KISS, I.: Trónbetöltés és ducatus, s. 747.

${ }^{131}$ HOMZA, Martin: Dzieje wczesnośredniowiecznego Spisza. In: Historia Scepusii I. Ed. Martin Homza, Stanisław A. Sroka, Bratislava - Kraków : Katedra slovenských dejín Filozofickej fakulty Univerzity Komenského - Instytut Historii Uniwersytetu Jagiellońskiego, 2009 , s. 137 a mapa č. 3.

132 KRISTÓ, Gy.: A XI. századi hercegség, s. 90-92.
} 
sa rozprestierali okolo Nitry a Biharu. László Koszta však nevylúčil, že by Kovin a Krašov mohli tiež nejakým spôsobom patrit' ku král'ovskému vojvodstvu. ${ }^{133}$ Attila Zsoldos naposledy zhrnul viacero argumentov v prospech toho, že vojvodstvo síce pozostávalo $\mathrm{z}$ dvoch väčších blokov, no zo začiatku zahŕňalo Biharsko a územie pät'kostolskej diecézy (čiže východnú čast' južného Zadunajska) a len neskôr, prostredníctvom výmeny majetkov Šalamúna a Gejzu, sa súčast'ou vojvodstva stalo Nitriansko. ${ }^{134} \mathrm{~S}$ dvomi strediskami rátal aj József Török, hoci zároveň predpokladal, že Ondrej zlúčil dve predošlé vojvodstvá, ponechajúc ich strediská. 135

Napriek všetkému vynaloženému úsiliu viacerých generácií našej historiografie sa teda nikomu nepodarilo dospiet' $\mathrm{k}$ úplne presnému a uspokojivému výsledku. Je však možné s istotou tvrdit', že vojvodstvo súviselo s komitátnym usporiadaním. A aj ked' nevlastnilo celé komitáty, môžeme sa domnievat', že v istých komitátoch mohli byt' županmi l'udia vojvodov. V spojitosti s územnou štruktúrou vojvodstva je isté, že v spoločnej podmnožine rozličných teórií sa vždy objavia dva názvy: Bihar a Nitra.

Absencia presnejšieho geografického ohraničenia vojvodskej moci je vážnym nedostatkom už len preto, lebo tak ako na základe skorších, tak aj súdobých analógií s uhorskými udalost'ami môžeme usúdit', že v prípade územného rozdelenia moci sa zúčastnení usilovali o presné vymedzenie a pomenovanie území, ktoré si delili. Tak tomu bolo aj vo vyššie spomenutých príkladoch z merovejského ${ }^{136}$ a karolovského obdobia. ${ }^{137}$ Avšak nemusíme brat' do úvahy len takéto všeobecné a časovo vel'mi vzdialené príklady. Gesta Galla Anonyma s takmer rigoróznou presnost’ou napísali, kto a aké územia v deleniach krajiny z roku 1097 a po ňom nasledujúcich získal. Podobne precízne informuje aj Kosmas o územiach, ktoré sa dostali do vlastníctva přemyslovských kniežat na Morave. ${ }^{138}$ Dokonca ešte aj závet Jaroslava Múdreho dbal s dôkladnou presnost'ou o to,

133 ZSOLDOS, A.: Az Árpádok és alattvalóik, s. 82; FONT, M.: A középkori Magyar Királyság, s. 68; KOSZTA, L.: A nyitrai püspökség létrejötte, s. 280.

${ }^{134}$ ZSOLDOS, Attila: Bihar megye korai története. In: Nagyvárad és Bihar története a korai középkorban. Szerk. Zsoldos Attila, Nagyvárad : Varadinum Kulturális Alapítvány, 2014, s. 183-185.

135 TÖRÖK, J.: A tizenegyedik század, s. 113.

${ }^{136}$ Deditque sors Charibertho regnum Childeberthi sedemque habere Parisius, Gunthramno vero regnum Chlodomeris ac tenere sedem Aurilianensem, Chilperico vero regnum Chlothari, patris eius, cathedramque Sessionas habere, Sygibertho quoque regnum Theuderici sedemque habere Remensim. Gregorii Turonensis Opera. Libri Historiarum X, Lib. IV. c. 22. MGH SRM I/1, s. 155.

${ }^{137}$ Capitularia regum Francorum. MGH Capitularia I, s. 126, nr. 45.

138 Post cuius obitum frater eius a Wratizlaus omnibus Boemiis faventibus sublimatur in solium, qui confestim Moravie regnum inter fratres suos dividit per medium, dans Ottoni 


\section{Dániel Bagi}

aby stanovil, kto má čo dostat'. Z príbehu, zachovanom v Povesti vremennych let, jednoznačne vysvitá, že to boli hlavné strediská Rusi. ${ }^{139}$ Jaroslavov najstarší syn dostal Kyjev, Novgorod, Pskov a Turov-Pinsk, dvaja d'alší, v roku 1054 ešte žijúci synovia Černigov, Tmutarakaň, ako aj Perejaslav a Rostov-Suzdal'. Navyše, závet kniežat'a zvýhodňoval vetvu vtedy už nežijúceho najstaršieho syna, ked' svojmu vnukovi Rastislavovi pridelil územia v juhozápadnej časti krajiny, pravdepodobne v Peremyšli. ${ }^{140}$

Lepšiemu pochopeniu nepomáha ani fráza bona regni v 88. kronikárskej kapitole. Je isté, že spoločné užívanie bohatstva král'ovstva hralo v myslení kronikára dôležitú úlohu, avšak kvôli nesmiernemu množstvu zásahov v rôznom čase do známeho textu kronikárskej kompozície ešte nie je isté ani to, či sa výraz mohol nachádzat' v pôvodnom texte. Termín vo forme regni bona alebo bona regni svedčí skôr o rímskom právnom myslení. ${ }^{141}$ Nie je vylúčené, že sa dostal do kroniky až v druhej polovici 12. storočia, alebo ešte neskôr. Ďalej ani výrazy regnum, proprietas, potestas regia, ani v iných kapitolách kroniky sa vyskytujúci výraz ducatus nepomáhajú v porozumení. V spojitosti s termínom ducatus treba konštatovat', že popri všeobecnom význame označujúcom mocenské kompetencie ho súčasníci chápali aj ako územie. V dvoch prípadoch, pri ostrihomskom stretnutí Gejzu a Šalamúna, ako aj pri konflikte po byzantských vojnách v roku 1071 sa môžeme jednoznačne dočítat', že Gejza odišiel in ducatum. ${ }^{142} \mathrm{~V}$ tomto ohl'ade je opät' potrebné upozornit' na niekdajšie konštatovanie Gyulu Kristóa, podl'a ktorého slová dux a ducatus môžu mat' viacero významov, tak ako podobné termíny všeobecne. Už len v spojitosti s majetkami kniežat’a Dávida je prípustné, aby sme ich preložili ako vlastníctvo. Nedostaneme sa d'alej ani ohl'adom pojmu regnum. V medzinárodnom medievistickom výskume sa z času na čas objavia nové pokusy o interpretáciu, ${ }^{143}$ ktoré sa pokúšajú o zladenie pojmu

orientalem plagam, quam ipse prius obtinuerat, que fuit aptior venatibus et abundantior piscibus, occidentalem vero, que est versus Teutonicos, dat Conrado, qui et ipse sciebat Teutonicam linguam. Regio autem illa est planior et campestris atque fertilior frugibus. Cosmae Pragensis Chronica Boemorum, Lib. 2. c. 18. MGH SRG N. S. 2, 110.

139 Povest'vremennych let. PLDR, s. 175-176.

140 FONT, M.: Oroszország, s. 45-46.

${ }^{141} \mathrm{~V}$ tom zmysle, že ide o král'ovské, resp. ríšske majetky sa to objavuje aj vo viacerých listinách Fridricha Barbarossu. Pozri APPELT, Heinrich (ed.): Friderici I. diplomata I - II. MGH Diplomata 10. Hannover : Hahnsche Buchhandlung, 1979, s. 133, nr. 80.

${ }^{142}$ rex ... dimisit ducem abire in ducatum. Chronici Hungarici compositio saeculi XIV., c. 112. SRH I, s. 378; Geysa rediit in ducatum. Chronici Hungarici compositio saeculi XIV., c. 110. SRH I, s. 376.

${ }^{143}$ Sumárne k prehl'adu nemeckého a francúzskeho bádania pozri najnovšie SCHIEFFER, Rudolf: Die internationale Forschung zur Staatlichkeit in der Karolingerzeit. In: Der Frühmittelalterliche Staat - europäische Perspektiven. Hg. von Walter Pohl, Veronika Wieser, Wien : Verlag der Österreichischen Akademie der Wissenschaften, 2009, s. 43-50. 
regnum a moderného poňatia štátu. Aj Hans-Werner Goetz, považovaný za bádatel'a znalého abstraktných historických pojmov, však dokázal zistit' len tol'ko, že pojem regnum môže byt' v abstraktnom zmysle nezriedka interpretovaný aj ako „štát“, ale sám nepopieral, že samotný termín aj v ním uvedených pramenných textoch nesie často i odlišný význam. ${ }^{144}$ Regnum sa obvykle vyskytuje vo význame "moc", „vláda“, „král’ovská moc“, „krajina“. V porovnaní s výrazmi ducatus, dux, alebo proprietas ducis sa síce l’ahšie interpretuje jeho aktuálny význam $v$ danej situácii, nedáva však odpoved' na otázku, aké územie pod ním súčasníci rozumeli.

Z vyššie uvedeného priamo vyplýva, že pramene nám poskytujú len vel'mi neistú odpoved' na otázku, čo si medzi sebou Arpádovci okolo roku 1048 rozdelili. Avšak aj málovravnost' kronikárskej kompozície pripúšt'a, aby sme pod rozdelením krajiny nemuseli rozumiet' len vytvorenie územného podielu, ale vo všeobecnosti del'bu moci, prípadne aj spoločné vlastníctvo jej finančných zdrojov. 0 tom poslednom svedčí rozdelenie koristi na buzaşskom majetku župana Vida po roku 1071, ktoré taktiež predstavovalo rozdelenie krajiny a moci. ${ }^{145}$

Osobitne v otázke vojvodských stredísk sa teda neposúvame vpred. Avšak, ak porovnáme uhorské vojvodské strediská so situáciou iných súčasných stredo- a východoeurópskych centier z hl'adiska funkcie, akú plnili v rozdelení krajiny, môžeme dosiahnut' pozoruhodný výsledok.

Ohl'adom porovnania dôležitosti dvoch predpokladaných vojvodských centier argumentoval László Koszta tým, že spočiatku mohol byt' Bihar významnejším strediskom vojvodstva, ${ }^{146}$ čo potvrdzuje aj to, že sa stal biskupským sídlom skôr. Podl'a neho začal význam Biharska klesat' od polovice 11. storočia v prospech Nitrianska, čo by sa dalo vysvetlit' návratom Bela domov z Pol'ska. Belo, azda aj pre svoje rodinné a dobré politické vzt'ahy s Piastovcami, chcel mat' pod svojou kontrolou Považie, ktoré predstavovalo hlavnú tranzitnú cestu do Pol’ska. K nárastu významu Nitry mohlo prispiet' aj to, že po obsadení Moravy Přemyslovcami nadobudla Nitra aj hranično-obrannú funkciu. A musíme vziat' na vedomie aj to, že v neskoršom vyostrenom konflikte Ondreja I. a Bela, ako aj v nadväzujúcom mocenskom boji ich synov mal Nitriansky

\footnotetext{
${ }^{144}$ GOETZ, Hans-Werner: Regnum. Zum politischen Denken der Karolingerzeit. In: GOETZ, Hans-Werner: Vorstellungsgeschichte. Gesammelte Schriften zu Wahrnehmungen, Deutungen und Vorstellungen im Mittelalter. Hg. von Anna Aurast, Simon Elling et alii, Bochum : Winkler, 2007, s. 219-272 (najmä 223, 235, 271).

145 thezaurum ... rex ... in quatuor partes divisit, et quartam partem duci, de tribus partibus unam haberet, ut omnibus militibus, secundam autem Vyd, tertiam autem Ilia. Chronici Hungarici compositio saeculi XIV., c. 109. SRH I, s. 375.

${ }^{146}$ KOSZTA, L.: A nyitrai püspökség létrejötte, s. 281.
} 
hrad strategický význam, ked'že odtial' bolo možné zorganizovat' obranu. ${ }^{147}$ Oproti tomu Attila Zsoldos predstavil naposledy vážne argumenty v prospech toho, že ešte aj v čase bitky pri Mogyoróde mohlo byt' Biharsko dôležitejším vojvodským sídlom. Svoje stanovisko založil v prvom rade na správe v 121. kapitole kronikárskej kompozície zo 14. storočia, podl'a ktorej v bitke pri Mogyoróde postavili Gejzu na čelo nitrianskych oddielov a Ladislava na čelo biharských, oni si však podl'a rozprávania kroniky vymenili znak, ${ }^{148}$ z čoho je možné vyvodit', že Gejza stál pôvodne na čele biharských oddielov a Ladislav na čele nitrianskych. ${ }^{149}$ Niet pochýb o tom, že exitujú argumenty pre aj proti obom koncepciám. O prvenstve Nitry hovorí okrem iného to, že medzi synmi Bela I. a olomouckými kniežatami pretrvával blízky vzt'ah, ked’že dcéra Bela I. sa vydala za olomoucké knieža Ota I. (Pekného), d’alej kvôli väzbám Gejzu na dvoch zoborských pustovníkov, ako aj preto, že podl'a kronikárskej kompozície chcel Šalamún pokračovat' vo vojne proti Gejzovi obliehaním Nitry po osudnej bitke pri Mogyoróde. ${ }^{150}$ Oproti tomu za Biharsko hovorí okolnost' odvoditel'ná z textu kroniky, podl'a ktorej sa Gejza uchýlil do Igfonského lesa v zime v roku 1073 a ešte predtým poslal biharského biskupa vyjednávat' $\mathrm{k}$ Šalamúnovi. ${ }^{151} \mathrm{~V}$ súvislosti s výmenou znakov v 121. kapitole kroniky si treba všimnút' gramatickú štruktúru textu, ktorá nepochybne nasvedčuje tomu, že výmena sa udiala skôr než útok na župana Vida. Avšak len z gramatického hl'adiska nie je možné vo vete určit', či sa to všetko chronologicky udialo po zostavení oddielov, alebo ešte predtým, teda či Gejza v bitke pri Mogyoróde stál skutočne na čele nitrianskeho vojska a vymenil si znak s Ladislavom len s ohl'adom na župana Vida, alebo sa obaja vojvodovia už vopred postavili na čelo oddielov s vymenenými zástavami. Z povahy veci, samozrejme, vyplýva, že logicky

\footnotetext{
${ }^{147}$ KOSZTA, L.: A nyitrai püspökség létrejötte, s. 281-282.

${ }^{148}$ Et in medio siquidem Bihoriensi agmine, Ladizlaum locato ex sinistra parte, Otthonem vero ex dextera constituerunt. Geysam vero in Nitriensi agmine in medio collocaverunt. Preterea ex utraque parte ter tria agmina quaternatim connectendo conservaverunt. Cumque rex de monte descenderet, exercitus Geyse, qui inferiori loco erat, videbatur elevantior cunctis exercitibus Salomonis. Quo viso dixit Erney ad comitem Vyd: "Mirum est, si agmina ista fugiant a facie nostra, quia Danubium post dorsum eorum non dimisissent; sed puto, ut ipsi proposuerunt vincere sive mori."Dux autem Ladizlaus ante exercitum suum super arduum equum residens gratia exortandi suos et enimandi in girum flexit abenas. Cumque tetigisset veprem lanceas, quedam hermelina albissima mirum in modum lancee eius inseditetsuper ipsam discurrendo in sinum eius usque devenit. Cum autem commisum esset prelium, comes Vyd et Bachienses in primo ictu a Bohemis miserabiliter sunt prostrati. Ladizlaus autem dux commutaverat signa sua cum vexillo ducis Geyse ea intentione, quod Salomon audicius invaderet illud agmen, in quo signa Geysee gestabantur, putans esse agmen Geyse, quem nuper devicerat. Chronici Hungarici compositio saeculi XIV., c. 121. SRH I, s. 389-390.

${ }^{149}$ ZSOLDOS, A.: Bihar megye, s. 187.

${ }^{150}$ Chronici Hungarici compositio saeculi XIV., c. 127. SRH I, s. 398-399.

${ }^{151}$ Chronici Hungarici compositio saeculi XIV., c. 113. SRH I, s. 378.
} 
by to mohlo byt' predstavitel'né len pred bitkou. Táto otázka si, podl'a môjho názoru, vyžaduje d’alšiu analýzu a diskusiu. Každopádne sa však javí, že Nitra a Bihar hrali závažnú úlohu v dejinách vojvodstva, obe sa pravidelne objavujú počas sporov vojvodov a král'ov.

Význam oboch vojvodských centier sa popri tom oplatí „odmerat" aj na inej stupnici, môžeme ich totiž porovnávat' s centrálnymi miestami, kde sa uskutočňoval výkon panovníckej moci. V tomto ohl'ade je nápadné, že s výnimkou Biharského biskupstva, založeného Ondrejom I. ${ }^{152}$ alebo ešte svätým Štefanom, ${ }^{153}$ neprinieslo rozdelenie krajiny so sebou aj delenie dôležitejších miest potrebných na výkon ústrednej panovníckej moci. Rovnako sa toto konštatovanie vzt'ahuje na biskupské sídla a aj na iné panovnícke sídla. Rozhodujúci dôkaz to nie je, ale ako vážny protiargument je možné spomenút' skúsenosti súvekých Piastovcov a Přemyslovcov. Vladislav Herman síce rozdelil v roku 1097 moc a krajinu medzi svojich dvoch synov, ale ponechal si hlavné miesta (sedes regni principales) svojej ríše. ${ }^{154}$ Tie si želal prenechat' svojim synom, Zbigniewovi a Boleslavovi, prostredníctvom závetu až po svojej smrti, dávajúc im presné pokyny. Zbigniew, popri strediskách, nachádzajúcich sa už vtedy v jeho vlastníctve, získal spomedzi hlavných centier mazovský Płock a oblúbenejšiemu Boleslavovi prislúbil Vroclav, Krakov, Sandomier. ${ }^{155}$ Ked' Vladislav Herman v roku 1102 zomrel, jeho synovia sa stretli v Płocku, na plánovanom mieste pohrebu kniežat’a, a ihned' sa aj pohádali, pretože sa nedokázali dohodnút' na rozdelení krajiny a pokladnice. Situácia mohla byt' vel'mi napätá, pretože bolo potrebné sprostredkovanie hniezdnenského arcibiskupa, aby sa vedeli dohodnút'.156 Boleslavovi pripadli dve centrálne sídla a získal aj hustejšie

${ }^{152}$ THOROCZKAY, Gábor: Szent István egyházmegyéi - Szent István püspökei. In: Szent István és az államalapítás. Szerk. Veszprémy László, Budapest : Osiris, 2002, s. 491; KOSZTA, L.: A nyitrai püspökség létrejötte, s. 281. Súhrnne pozri KRISTÓ, Gyula: A vármegyék kialakulása Magyarországon. Budapest : Magvető Könyvkiadó, 1988, s. 474-475; KMTL, s. 712 (Tibor Almási).

153 PAULER, Gy.: A magyar nemzet története I, s. 398 (a poznámka č. 92); HÓMAN, B. SZEKFÜ, Gy.: Magyar történet I, s. 200; GYÖRFFY, Gy.: István király, s. 377; SZÁNTÓ, Konrád: A katolikus egyház története I. Budapest : Ecclesia Könyvkiadó, 1987, s. 314.

${ }^{154}$ sed de manu sedes regni principales non dimisit. Galli Anonymi chronicae et gesta ducum sive principum Polonorum, Lib. II. c. 7. MPH N. S. 2, s. 74.

155 Post obitum quidem meum Zbigneus cum hoc, quod habet, Mazouiam simul habeat, Bolezlauus vero, legitimus filius meus, in Wratislav et in Cracou et in Sudomir sedes regni principales obtineat. Galli Anonymi chronicae et gesta ducum sive principum Polonorum, Lib. II. c. 8. MPH N. S. 2, s. 75.

${ }^{156}$ Advenientes autem ambo fratres, adhuc in sepulto patre magnum inter se pene de divisione thesaurorum et regni discidium habuerunt. sed divina gratia inspirante et archiepiscopo sene fideli mediante, preceptum viventis in presencia mortui tenuerunt. Galli Anonymi chronicae et gesta ducum sive principum Polonorum, Lib. II. c. 21. MPH N. S. 2, s. 88. 


\section{Dániel Bagi}

obývané časti krajiny. ${ }^{157}$ Príbeh, zapísaný v gestách Galla Anonyma, ktoré vznikli okolo roku 1113, je poučný v dvoch ohl'adoch. Pre knieža, oznamujúceho svoju poslednú vôl'u, ako aj pre jeho synov bolo dôležité, aby presne určili, čo komu bude patrit'. Okrem toho pri územnom rozdelení moci mali hlavnú úlohu sedes regni principales, čiže hlavné centrálne miesta piastovskej monarchie. 0 ich vlastníctvo zápasil otec so synmi a neskôr obaja bratia navzájom. Najneskôr pri rozdelení krajiny v roku 1102 pripadli do rúk Zbigniewa aspoň dve, avšak možno až tri biskupské sídla: Poznaň, Hniezdno a pravdepodobne aj Płock, založený po roku 1075. Rovnako si bratia podelili tie hlavné hrady, ktorých vlastníctvo bolo nevyhnutne dôležité z hl'adiska výkonu moci, teda malopol'ské a vel'kopol'ské, ako aj sliezske hrady (civitates), ktoré boli centrálnymi miestami piastovskej vlády od začiatku 11. storočia. Podobne núti k zamysleniu aj spôsob rozdelenia krajiny Přemyslovcov.

Opät' musíme pripomenút', že podl'a typológie oddelenej vlády, vypracovanej Gyulom Kristóm, najdôležitejšou spoločnou črtou stredo- a východoeurópskych vojvodstiev je ich vznik d'aleko od centrálnych oblastí, v okrajových končinách krajín ovládaných dynastiami. ${ }^{158}$ Túto tézu však v prípade Pol'ska kvôli rozdeleniu centrálnych lokalít určite nie je možné potvrdit'. Ohl'adom českých krajín je nevyhnutné korigovat' ju natol'ko, nakol'ko to potvrdzujú novšie výskumy. Vláda Přemyslovcov sa na Morave presadila vel'mi skoro, už pred miléniom, a pravdepodobne sa vybudovala postupne po zániku pol'skej vlády okolo roku 1002. Na to poukazuje okrem iného nález mincí kniežat’a Boleslava II. pri hrade Staré Zámky pri Brne. ${ }^{159}$ Hlavná línia výskumu datuje definitívne pripojenie Moravy k Čechám do doby medzi rokmi 1013 a 1023. Okrem toho už z 30. rokov 11. storočia máme pramene, ktoré potvrdzujú, že Břetislav ako poverenec svojho otca zaviedol vládu přemyslovskej dynastie na Morave. Máme k dispozícii zakladaciu listinu kolegiátnej kapituly v Starej Boleslavi, zachovanú v novovekom falze, ${ }^{160}$ ktorej údaje však môžu pochádzat' z pôvodného, alebo jemu blízkeho dokumentu. ${ }^{161}$ Kosmas $^{162}$ kladie založenie kapituly

\footnotetext{
157 Bolezlauus tamen legitimus duas sedes regni principales partemque populosiorem obtinuit. Galli Anonymi chronicae et gesta ducum sive principum Polonorum, Lib. II. c. 21. MPH N. S. 2, s. 88.

${ }^{158}$ KRISTÓ, Gy.: A XI. századi hercegség, s. 14-16.

${ }^{159}$ PROCHÁZKA, Rudolf: Zur Funktion der mährischen Burgen des 10-12. Jahrhunderts. In: Frühgeschichtliche Zentralorte in Mitteleuropa. Hg. von Jiři Macháček, Šimon Ungerman, Bonn : Habelt, 2011, s. 613.

160 CDB I, s. 361, nr. 382.

${ }^{161}$ Pozri SLÁMA, Jiř́: Der ökonomische Wandel im Přemyslidenstaat unter der Herrschaft der Nachfolger Boleslavs II. In: Boleslav II. Der Tschechische Staat um 1000, seine Herrscher und Ökonomik. Internationales Symposium, Praha 9-10. Februar 1999. Hg. von Petr Sommer, Praha : Filosofia, 2001, s. 141.

162 Cosmae Pragensis Chronica Boemorum, Lib. II. c. 13. MGH SRG N. S. 2, s. 100.
} 
do roku 1046. Z listiny poznávame kontúry nového hradného systému založeného Břetislavom. Jeho hrady boli základom přemyslovskej moci na Morave a zároveň aj tranzitnými stanicami obchodu s otrokmi smerujúceho do Uhorska. Na druhej strane listina informuje aj o tom, že Přemyslovci už okolo roku 1045 ovládali dôležité moravské lokality, pretože za vlády českého kniežat’a Břetislava I. sa peniaze prichádzajúce z Moravy dostali do českých cirkevných inštitúcií ako kniežacie dary. ${ }^{163}$ Teda okolo roku 1046 už k vlastným majetkom Přemyslovcov patril Olomouc, Znojmo, Brno, ako aj početné menšie hrady. Olomouc a Brno v žiadnom prípade nemôžeme považovat' za periférne. Tak v roku 1055 získali „hlavnú siet'“ moravských hradov mladší synovia kniežat'a Břetislava. Tieto hrady, hoci sa nenachádzali v Čechách, už dávno boli moravskými strediskami moci Přemyslovcov.

Presný územný rozsah Arpádovcami spravovaného vojvodstva môžeme však, aspoň na základe dostupných prameňov, zistit' len vel'mi t’ažko. Navyše sa zdá, že príslušníci uhorskej vládnucej dynastie sa, na rozdiel od svojich stredo- a východoeurópskych súčasníkov, nesnažili zapojit' centrálne miesta dynastickej moci do del'by. A to všetko je nanajvýš pozoruhodné. Celú vec je totiž nutné preskúmat' aj z iného uhla pohl'adu. Treba zistit', akými skutočnými kompetenciami disponovali vojvodovia 11. storočia, čiže aké funkcie mohli mat' historikmi predpokladané vojvodské strediská. Zaujíma nás to už len preto, lebo naša staršia i novšia historiografia priradila král'ovskému vojvodstvu prísny, takmer až verejnoprávny charakter, prisudzujúc mu vel'mi rozhodné, hospodárske, politické, súhrnne „štátne“ funkcie. Hóman o Belovi poznamenal, že vo svojej časti krajiny vykonával plnú panovnícku moc, svojmu bratovi však „dlhoval bezpodmienečnú vernost' a vazalskú úctu“. A traja král'ovskí vojvodovia v 11. storočí boli, podl'a jeho názoru, takmer neobmedzenými vládcami. ${ }^{164} \mathrm{~S}$ týmto názorom súhlasila aj neskoršia mad'arská medievistika. Gyula Kristó priamo pojednával o suverenite vojvodstva, štátno-územnom vyčlenení a definoval ho ako podštát. ${ }^{165}$ Podl'a Márty Font disponovalo vojvodstvo takmer král'ovskými právami, hoci zahraničnopoliticky nebolo samostatné. ${ }^{166}$ Naposledy zas László Koszta zaujal stanovisko, že vojvodstvo bolo takmer štátom $v$ štáte. ${ }^{167}$

Nie je dôvod pochybovat' o tom, že vojvodstvo a vojvodská moc mohli mat' vel'mi rozsiahlu pôsobnost'. Pýtame sa však, či je možné a či sa vôbec

\footnotetext{
163 SLÁMA, J.: Der ökonomische Wandel, s. 143 (a poznámka č. 21).

${ }^{164}$ HÓMAN, B. - SZEKFÚ, Gy.: Magyar történet I, s. 259, 324.

165 KRISTÓ, Gy.: A feudális széttagolódás, s. 66, 74.

${ }^{166}$ FONT, M.: A középkori Magyar Királyság, s. 69.

${ }^{167}$ KOSZTA, L.: A nyitrai püspökség létrejötte, s. 280.
} 


\section{Dániel Bagi}

oplatí sledovat' funkcie vojvodstva, prípadne jeho stredo- a východoeurópskych ekvivalentov, z pohl'adu verejnej moci? Spomenuli sme práce pojednávajúce o král'ovskom vojvodstve v rámci štátnych modelov 19. 20 . storočia, ${ }^{168}$ ktoré „vojvodstvá“ považovali za výsledok delenia „štátu“. Celú vec však si môžeme priblížit’ aj z inej strany, ako imitatio, čiže kopírovanie, napodobňovanie a nasledovanie funkcií král'ovskej, prípadne kniežacej moci. Pri vzniku stredo- a východoeurópskych monarchií mohlo zohrat’ úlohu imitatio imperii, napodobňovanie ríše. Na to upozornil už József Deér v súvislosti s vytvorením svätoštefanskej monarchie. ${ }^{169}$ Podobné názory nezastávajú len mad'arskí historici. ${ }^{170}$ Popri imitatio imperii je pravdepodobné, že v okruhu stredo-východoeurópskych panovníckych dynastií sa stávalo, že členovia rodiny, ktorí pri delení moci nadobudli moc a majetky, mohli mat' záujem aj o napodobňovanie král'ovskej, prípadne kniežacej moci. Imitatio regni, nasledovanie a napodobňovanie panovníkov, nekončilo v kruhu príslušníkov vlastnej dynastie. Zdá sa, že aj elity, sústred'ujúce sa od druhej polovice 11. storočia okolo panovníkov v čoraz väčšom počte, považovali panovnícku rodinu za svoj vzor. ${ }^{171}$ Dobrým príkladom sú donácie súkromných majetkov a zakladanie cirkevných ustanovizní objavujúce sa v zriedkavom listinnom materiáli, ako aj v kronike. Zriadenia, prípadne donácie majetkov palatínom Radom, županom Petrom, palatínom Atha/Otom, ${ }^{172}$ zrejme sledovali popri vlastnom obohatení a ambíciách aj imitatio dynastie. Je

\footnotetext{
168 Najmä KRZEMIEŃSKA, Barbara: Die Rotunde in Znojmo und die Stellung Mährens in [sic] böhmischen Přemyslidenstaat. In: Historica 27. 1987, s. 54.

${ }^{169}$ DEÉR, J.: Pogány magyarság, s. 103.

${ }^{170}$ Michałowski pokladal napríklad Krakov za repliku Aachenu (MICHAŁOWSKI, Roman: Princeps fundator. Studium z dziejów kultury politycznej w Polsce X-XIII wieku. Warszawa : Uniwersytet Warszawski, Instytut Historyczny, 1989, s. 87). Pauk zasa považoval Płock za imitáciu Speyeru (PAUK, Marcin Rafał: Płock i Spira. Piastowska „imitatio imperii” na przełomie XI-XII wieku? In: Świat średniowiecza. Studia ofiarowane Profesorowi Henrykowi Samsonowiczowi. Ed. Antoni Bartoszewicz, Warszawa : Wydawnictwo Uniwersytetu Warszawskiego, 2010, s. 497).

171 Ohl'adom Piastovcov a Přemyslovcov pozri MICHAŁOWSKI, R.: Princeps fundator, s. 108110. K otázke posledne SKWIERCZYŃSKI, Krzysztof: Imitatio regni. Adelige Stiftungen im Polen des 11. und 12. Jh. In: Monarchische und adelige Sakralstiftungen in Polen. Hg. von Eduard Mühle, Berlin : De Gruyter, 2013, s. 173-174.

172 GYÖRFFY, Georgius (ed.): Diplomata Hungariae antiquissima, accedunt epistolae et acta ad historiam Hungariae pertinentia I. (ab anno 1000 usque ad annum 1131). Adiuverunt Johannes Bapt. Borsa, Franciscus L. Hervay, Bernardus L. Kumorovitz et Julius Moravcsik. (d'alej len DHA I) Budapestini : In Aedibus Academiae Scientiarum Hungaricae, 1992, s. $161, \mathrm{nr} .46, \mathrm{~s} .184, \mathrm{nr}$. 58. In reversu autem eorum Atha palatinus rogavit regem et ducem ut in constructione monasteri sui quo in honore Sancti Iacobi edificaverat, in Zelyz interessent. Chronici Hungarici compositio saeculi XIV., c. 99. SRH I, s. 366. K zakladacej listine kláštora pozri DHA I, s. 170-174, nr. 50/II. K problémom chronológie udalostí zaznamenaných v listine a v kronike pozri DHA I, s. 170-171. V kontexte vzt'ahov Arpádovcov a Přemyslovcov pozri KOSZTA, L.: A hradištei bencés monostor, s. 421.
} 
pravdepodobné, že to motivovalo zriad'ovatel'ov cirkevných ustanovizní, ktorí pozývali na vysvätenie svojho cirkevného objektu aj panovníkov. ${ }^{173}$ Okrem zselicszentjakabskej vysviacky je iste takým aj príbeh dochovaný v gestách Galla Anonyma zaznamenávajúci cirkevnú fundáciu v Rude, na ktoré zakladatel' pozval aj knieža so sprievodom. ${ }^{174}$ Ešte zaujímavejší je príbeh zachovaný v Kosmovej kronike o Mstišovi, ktorý osobne pozval Vratislava II., aby sa zúčastnil na vysvätení jeho kostola postaveného v Bíline v severozápadných Čechách. ${ }^{175}$ Príbeh je pozoruhodný z viacerých hl'adísk. Podl'a Kosmasa sa knieža síce chcel pomstit' pozývatel'ovi za dávnejšiu urážku, jeho pozvaniu však vyhovel aj napriek svojej krivde.

Pri rozdelení moci teda hralo dôležitú úlohu imitatio, napodobňovanie král'ovskej alebo kniežacej moci. Samozrejme to, do akej miery bolo možné získat' určité okruhy pôsobnosti, bolo opät' len určené vzt'ahom medzi účastníkmi delení. Oprávnene sa môžeme pýtat', či „osvojenie si“ jednotlivých prvkov panovníckych právomocí trvalo dlhšie, či sa vojvodská moc prispôsobovala král'ovskému majestátu pomaly, ${ }^{176}$ alebo či sa rozdelenie moci od začiatku spájalo s rozdelením určitých okruhov pôsobnosti, ktoré bolo možné stratit' pri naštrbení vzt'ahu medzi král'om a vojvodom? Príkladom nech je vojvodské právo na razenie mincí a donáciu majetku.

Král'ovskí vojvodovia Belo a Gejza vo svojej vojvodskej pôsobnosti dávali razit' aj mince. 1770 mieste vojvodskej mincovne sa však názory rozchádzajú. Slovenský výskum, ktorý kladie príliš vel'ký dôraz na úlohu

\footnotetext{
173 Staršia historiografia to pokladala za zriedkavú, výnimočnú príležitost'. Pozri MÁLYUSZ, Elemér: Egyházi társadalom a középkori Magyarországon. Budapest : Műszaki Kiadó, 2007, s. 23-24.

${ }^{174}$ Forte quidam nobilis in confinio terre ecclesiam construxit, ad cuius consecracionem Bolezlauum ducem, adhuc satis puerum cum suis iuvenibus invitavit. Galli Anonymi chronicae et gesta ducum sive principum Polonorum, Lib. II. c. 33. MPH N. S. 2, s. 100.

${ }^{175}$ Ea tempestate Mztis comes urbis Beline, filius Boris, vir magne audacie, maioris eloquentie nec minoris prudentie, quamvis non inmemor, quod suspectum ducem habuerit, quia eius coniugem sibi quandoque domino suo commissam in custodia tenuerit tamen audacter palatium ducis ingressus rogaturus eum his verbis suppliciter est aggressus: „Fratris tui «, inquit, "per gratiam in honore sancti Petri apostoli edificavi ecclesiam, cuius ad dedicationis sollempnitatem quo dignemini adventare simul et urbem adventu tuo letificare, supplices meas ne despice preces. "Ille quamvis non inmemor accepte iniurie, quam olim sibi fecerat in coniuge, tamen propter novitatem suam dissimulans in corde quam habuit iram, dixit: „Ego veniam, civitatem letificabo meam et, quod res et iusticia postulat, faciam. «Hoc verbum, quod locutus est princeps, non intellexit comes et magnas duci agens grates letus abiit et parat, que sunt necessaria ad magna convivia. Cosmae Pragensis Chronica Boemorum, Lib. II. c. 19. MGH SRG N. S. 2, s. 111.

176 KOSZTA, L.: A nyitrai püspökség létrejötte, s. 282-283.

${ }^{177}$ Najnovšie, aj so zhrnutím staršej literatúry, pozri KOSZTA, L.: A nyitrai püspökség létrejötte, s. 285.
} 
Nitry, hl'adá túto mincovňu v Nitre. ${ }^{178}$ Oproti tomu starší mad'arský výskum zdôrazňoval význam Biharu, preto tu hl'adal aj vojvodskú mincovňu. ${ }^{179}$ Novšie bádatel'ské názory o mieste razenia vojvodských mincí sú trochu opatrnejšie. Podl'a Lászlóa Kovácsa, ktorý naposledy systematizoval numizmatické pamiatky včasnej arpádovskej doby, nie je možné jednoznačne určit', kde táto mincovňa bola. To však nespochybňuje mincovníctvo vojvodov. ${ }^{180}$ Nezávisle od neznalosti miesta vojvodskej mincovne niet pochybností, že vojvodstvo či vojvodský majestát mali aj takúto funkciu. Môžeme teda vojvodské razenie peňazí považovat' za samostatnú, od král'ovskej moci nezávislú funkciu? Táto otázka podnecuje k hl'adaniu analógií u Piastovcov a Přemyslovcov. V Pol'sku poznáme mince od čias Boleslava I. (Chrabrého), stopy pravidelného razenia peňazí sú však preukázatel'né len od čias Boleslava II. (Smelého). ${ }^{181}$ Je vel'ká škoda, že s výnimkou niekol'kých dodnes neidentifikovaných mincí nemôžeme priradit' mincu k samostatnej vláde Zbigniewa. ${ }^{182}$ Vel'ká neistota vládne aj pri minciach razených za spoločnej vlády Vladislava Hermana a Boleslava III., ked’že sa na seba natol'ko podobajú, že ich rozlíšenie je takmer nemožné. ${ }^{183}$ Taktiež nie je možné navzájom rozlíšit' mince Boleslava III. razené medzi rokmi 1097 a 1102, 1102 a 1112 a neskôr razené mince. Preto nevieme, či Piastovci razili mince paralelne. Ešte zaujímavejšie je přemyslovské mincovníctvo. ${ }^{184}$ Kosmas napísal, že už v čase ustanovenia Břetislava I. za knieža bolo zvykom hádzat' peniaze medzi prítomných l'udí. ${ }^{185}$ Nevieme, či Kosmas, ktorý žil takmer o sto

\footnotetext{
${ }^{178}$ HUNKA, Ján: Mincovníctvo uhorských vojvodov v druhej polovici 11. storočia. In: Slovenská numizmatika. roč. 14, 1996, s. 83-85.

${ }^{179}$ GEDAI, István: Numismatische Angaben zur Frage des „Dukatus“. In: A Móra Ferenc Múzeum Évkönyve 2. 1969, s. 209.

180 KOVÁCS, László: A kora Árpád-kori pénzverésről. Éremtani és régészeti tanulmányok a Kárpát-medence I. (Szent) István és II. (Vak) Béla uralkodása közötti időszakának (1000 1141) érméiről. Budapest : Magyar Tudományos Akadémia, 1997, s. 130.

181 SUCHODOLSKI, Stanisław: Moneta możnowładcza i kościelna $w$ Polsce wczesnośredniowiecznej. Wrocław - Warszawa : Zakład Narodowy im. Ossolińskich - Wydawnictwo Polskiej Akademii Nauk, 1987.

182 KĘDZIERSKI, Adam: Czy istnieją monety Zbigniewa, syna Władysława Hermana? In: Wiadomości numizmatyczne. roč. 49, č. 1, 2005, s. 34-35.

183 KĘDZIERSKI, A.: Czy istnieją monety, s. 37.

${ }^{184}$ Ku klasifikácii českých a moravských denárov pozri CACH, František: Nejstarší české mince I - III. Praha : Numismatická společnost československá, 1970 - 1974 (I. zväzok: České denáry do mincovní reformy Břetislava I. Praha 1970; II. zväzok: České a moravské denáry od mincovní reformy Břetislava I. do doby brakteátové. Praha 1972); ŠMERDA, Jan: Denáry české a moravské. Katalog mincí českého státu od X. do počátku XIII. století. Brno : Nakladatelství Datel, 1996, s. 96-115.

185 et sicut semper in electione ducis faciunt, per superioris aule cancellos decem milla nummorum aut plus per populum spargunt, ne ducem in solio comprimant, sed potius sparsos nummos rapiant. Cosmae Pragensis Chronica Boemorum, Lib. I. c. 42. MGH SRG N. S. 2, s. 78.
} 
rokov neskôr, chcel len zveličovat', alebo skutočne písomne zaznamenal existujúcu tradíciu. Nevieme, či to boli kniežat'om razené a skutočne používané peniaze, alebo mince zvlášt' vyrobené na túto príležitost'. ${ }^{186}$ Je však nepochybné, že razenie a obeh peňazí v Čechách mali v Kosmovej dobe ${ }^{187}$ vel'mi starú tradíciu. Predpokladá sa, že prvá mincovňa bola na Pražskom hrade a počiatky razenia peňazí na Morave sa kladú do rokov 1013 - 1020, teda do obdobia vybudovania vlády Přemyslovcov na Morave, a určite do moravského obdobia Břetislava I. (pred rokom 1034). ${ }^{188}$ Najstaršia moravská mincovňa bola celkom iste v Olomouci, čo môžeme zdôvodnit' nielen predpokladanou kontinuitou vel'komoravskej cirkevnej organizácie v Olomouci, ale aj nespochybnitel'nou skutočnost'ou, že spomedzi troch nových přemyslovských stredísk, vystavaných na začiatku 11. storočia, tu postavili najväčší hrad. Aj samotný Břetislav sa počas svojho moravského obdobia najradšej zdržiaval práve v Olomouci. ${ }^{189}$ Podarilo sa identifikovat' viacero denárov Břetislava I., ktoré nesú meno svätého Petra, patróna kostola Olomouckého hradu. Zakladatel' razby peňazí na Morave si teda za sídlo mincovne vybral Olomouc. Spornejším je čas vzniku kniežacej mincovne v Brne, v druhom väčšom moravskom hradnom stredisku. K dispozícii máme listinu Břetislava I. datovanú do roku 1048, ktorou udel'uje dary ním založenému rajhradskému kláštoru. ${ }^{190}$ Listina je falzifikátom z 13. storočia, ked' ju vyhotovili ako dôkaz v súdnom spore o kláštorné majetky, no určité jej časti sa opierajú o pôvodné údaje. ${ }^{191}$ Podl'a zmienky

\footnotetext{
186 Takto to predpokladá napr. PAUK, Marcin Rafał: Moneta w kulturze średniowiecza wokół denarów czeskich z pierwszej połowy XII stulecia. In: Kwartalnik Historyczny. roč. 119, č. 3, 2012, s. 470.

187 V súvislosti s finančnými záležitost’ami začiatku 12. storočia nás informuje sám Kosmas, a to nevel'mi lichotivými slovami, ktoré napísal o pokrstenom Židovi Jakubovi Apellovi dosadenom do kniežacej pokladnice: „Ah quantum de mammona inquitatis ex domo eiusdem subplantatoris sublatum est et in fiscum ducis redactum!" Cosmae Pragensis Chronica Boemorum, Lib. III. c. 57. MGH SRG N. S. 2, s. 232.

188 ŽEMLIČKA, J.: Čechy v době knížecí, s. 161-163; SLÁMA, J.: Der ökonomische Wandel, s. 144; VIDEMAN, Jan - MACHÁČEK, Jiř́i: Nové mincovní nálezy z dolního Podyjí v kontextu raně středověké Moravy. In: Archeologické rozhledy. roč. 65, č. 4, 2013, s. 855.

189 POŠVÁ̌̆, Jaroslav: Moravské mincovny. Brno : Moravské museum, 1970, s. 70.

${ }^{190}$ BOCZEK, Antonius (ed.): Codex diplomaticus et epistolaris Moraviae I. (896 - 1199). (d’alej len CDM I.) Olomucii : Ex Typographia Aloysii Skarnitzl, 1836, s. 122-123, nr. 137.

191 POŠVÁ́̌, J.: Moravské mincovny, s. 11 (a poznámka č. 29). K listine pozri MĚŘíNSKÝ, Zdeněk: Církevní instituce na Moravě a historické pozadí vzniku třebíčského kláštera. In: Ve stopách sv. Benedikta. Sborník př́spěvků z konference Středověké kláštery v zemích Koruny české konané v dnech 24. - 25. května 2001 v Třebíči. Ed. Libor Jan, Petr Obšusta, Brno : Matice moravská, 2002, s. 58. K okolnostiam sfalšovania dokumentu pozri JAN, Libor: Počátky benediktinů na Moravě a rajhradský klášter. In: Ve stopách sv. Benedikta. Sborník př́spěvků z konference Středověké kláštery v zemích Koruny české konané v dnech 24. - 25. května 2001 v Třebíči. Ed. Libor Jan, Petr Obšusta, Brno : Matice moravská, 2002, s. 25.
} 


\section{Dániel Bagi}

$\mathrm{v}$ listine Břetislav daroval kláštoru aj desatinu výt’ažku $\mathrm{z}$ razenia mincí. ${ }^{192}$ Musíme zdôraznit', že nie je možné rozhodnút' sa, či decimi nummi je len želaním falzifikátora z 13 . storočia, alebo je to skutočný dar Břetislava I. Ak prijmeme druhú domnienku, tak môžeme predpokladat', že už pred rokom 1055 pracovala aj brnenská mincovňa, ktorá pokračovala aj v dobe údelného kniežatstva po roku 1055. Okrem moravských denárov Oldřicha, Břetislava I. a Spytihněva II. ${ }^{193}$ dali aj neskôr panujúce olomoucké, brnenské a znojemské kniežatá razit’ mnoho denárov. V Olomouci to môžeme sledovat' od čias Vratislava II. V tej dobe dávalo každé moravské knieža do obehu vlastné mince. ${ }^{194}$ Obzvlášt' to platí pre skutočného zakladatel'a olomouckej vetvy Přemyslovcov Ota I., a jeho syna Ota II. ${ }^{195}$ Menej mincí sa viaže k brnenským a znojemským členom rodiny. ${ }^{196}$ Starší i novší výskum dospel k stanovisku, že olomoucká a brnenská mincovňa boli len „dekoncentrovanými orgánmi“ mincovne pražských kniežat. Neboli samostatné, lebo razenie peňazí bolo, podobne ako v dobe Karola Vel'kého, výlučným panovníckym monopolom. ${ }^{197}$ To znamená, že moravské kniežatá síce mohli dávat' do obehu mince s vlastnou podobizňou, ale len so súhlasom pražských kniežat. No v niekol'kých prípadoch, napríklad medzi rokmi 1087 a 1092, ked' Vratislav II. chcel násilne zakročit' proti svojim moravským príbuzným, je zrejmé, že moravské kniežatá sa aj samostatnou razbou mincí pokúšali klást' odpor svojvôli pražského kniežat'a či král'a. Poznáme až dve mince Eufémie, vdovy po olomouckom kniežati Otovi I. (Peknom). ${ }^{198}$ O Eufémii sa predpokladá, že vykonávala regentské povinnosti v mene svojich maloletých synov Svätopluka a Ota. Obe mince sa datujú medzi roky 1087 a 1095. Medzitým aj Vratislav II. a jeho syn Boleslav dali spoločne razit' moravské mince, ktoré majú vyrazenú postavu s korunou a nápis BOLEZLAV DUX. ${ }^{199}$ Minca jednoznačne potvrdzuje, že pražské kniežatá sa pokúsili podriadit' si svojich olomouckých príbuzných aj v razení peňazí. Nemusela to byt' len svojvôl'a Vratislava II., ktorého Kosmas opísal ako netvora, ale jeho ciel'avedomá politika. Vratislav po predčasnej smrti

\footnotetext{
${ }^{192}$ Ad hec in Brunensi provincia decimationem frumenti ac decimi nummi. CDM I, s. 123, nr. 137.

193 ŠMERDA, J.: Denáry české a moravské, s. 96.

194 ŠMERDA, J.: Denáry české a moravské, s. 98.

195 ŠMERDA, J.: Denáry české a moravské, s. 99, 104-106.

196 ŠMERDA, J.: Denáry české a moravské, s. 112-115.

197 POŠVÁ̌̆, J.: Moravské mincovny, s. 12; ŽEMLIČKA, J.: Čechy v době knížecí, s. 162; WIHODA, M.: Morava v době knížecí, s. 127.

${ }^{198}$ CACH, F.: Nejstarší české mince II, č. 379-380; ŠMERDA, J.: Denáry české a moravské, s. 100-101, č. 336, 344.

${ }^{199}$ CACH, F.: Nejstarší české mince II, č. 355; ŠMERDA, J.: Denáry české a moravské, s. 101, č. 337-340b.
} 
Boleslava dal spoločne so synom Břetislavom, ktorý pochádzal z iného manželstva, razit' moravské mince, ktoré sa vo svojej symbolike zhodovali s predošlými mincami. ${ }^{200}$

Vrát'me sa k otázke, či sa vojvodská moc časom prispôsobila král'ovskému majestátu alebo naopak. Vojvodovia od začiatku disponovali určitými funkciami, ktoré neskôr, v dôsledku konfliktov, stratili. Kým Belo a Gejza dávali do obehu vojvodské denáre, tak práve v poslednom období vojvodstva, ked' vojvodskú moc sprevádzala aj korunovácia, razenie vojvodských mincí končí. Král' Koloman sa od začiatku usiloval obmedzit' Álmošove vojvodské právomoci, čo mohlo mat' za následok aj ukončenie razenia peňazí. ${ }^{201}$ Vzt'ah Kolomana a Álmoša zatieňoval konflikt. To mohlo zabránit' tomu, aby Álmoš využíval vojvodské právo na razbu peňazí, existujúce preukázatel'ne od čias Ondreja a Bela.V prípade razenia peňazí sa teda neprejavuje pomalé vyrovnávanie král'ovských a vojvodských pôsobností, ale práve naopak. Vidíme odobratie (alebo zrušenie) skoršej právomoci. Navyše, t'ažko sa zbavíme podozrenia, že razenie peňazí nebolo právom oddelenej oblastnej vlády, ale vždy ho mal dux. Bola to právomoc, o ktorú sa král' mohol delit'. Tak ju Belo a Gejza mohli vykonávat' a Álmoš, ktorý mal od začiatku zlý vzt'ah so svojím bratom, nemohol.

Toto podozrenie potvrdzujú aj nasledujúce skutočnosti. Stručne už bola reč o tom, že elity zoskupené okolo príslušníkov dynastie mali záujem o imitatio panovníckej moci, a vedome sa usilovali o to, aby sa donáciami a zriadeniami podobali príslušníkom dynastie. Niektorí z nich to robili natol'ko úspešne, že sa dostali až príliš blízko k panovníkom. Nemusíme podrobnejšie predstavovat' župana Vida, ktorý sa, aspoň podl'a kronikárskej kompozície zo 14. storočia, usiloval o vojvodskú moc, aby sa tak dostal na úroveň dynastie. Svojho „župana Vida“ mal aj pol'ský knieža Vladislav Herman. Bol ním mocný vojvoda Setiech. Setiech, pôsobiaci medzi rokmi 1079 a 1100, mohol disponovat' mnohými majetkami v rôznych častiach krajiny, s ktorými môžu byt' spojené aj viaceré jeho cirkevné fundácie. ${ }^{202}$ Zdá sa však, že vojvoda Setiech sa neuspokojil s hromadením majetkov, ale dával razit' aj peniaze. Poznáme dve rôzne razby denáru, na ktorých figuruje jeho meno v tvare ZETECH. ${ }^{203}$ Nepodarilo sa dospiet' ku konsenzu v tom, či vlastná minca vojvodu slúžila na hospodárske, prípadne sakrálne účely, alebo či súvisela s tým, že vojvoda

${ }^{200} \mathrm{CACH}, \mathrm{F} .:$ Nejstarší české mince II, č. 358; ŠMERDA, J.: Denáry české a moravské, s. 101, č. 341-344.

${ }^{201}$ KRISTÓ, Gy.: A feudális széttagolódás, s. 69.

202 DOBOSZ, Józef: Monarchia i możni wobec Kościoła w Polsce do poczatku XIII wieku. Poznań : Wydawnictwo Poznańskie, 2002, s. 256-259.

${ }^{203}$ Ich detailný opis pozri v SUCHODOLSKI, S.: Moneta możnowładcza, s. 14-33. 


\section{Dániel Bagi}

si chcel privlastnit' moc Piastovcov a chcel sa povzniest' k panovníckemu rodu. K možnosti rozhodnutia v tejto otázke výrazne prispelo, že sa nedávno objavil aj tretí typ jeho denára, na ktorom nie je zobrazený nápis ZETECH, ani jeho symboly objavujúce sa na predošlých vojvodských denároch, avšak váha a výzdoba razby vykazuje podobnost' s predošlými dvomi. ${ }^{204}$ Zdá sa, že neskôr nájdené mince mohli slúžit’ na hospodárske účely, kým mince nesúce meno a znak vojvodovej rodiny môžu nasvedčovat' tomu, že s povolením Vladislava Hermana získal aj panovnícku právomoc. Na základe toho je možné, že sa odhodlal získat' politickú moc. ${ }^{205}$ Mince vojvodu Setiecha podnecujú k zamysleniu aj preto, lebo medzi moravskými mincami je razba s čitatel’ným nápisom VSEBOR. Sú to skoré moravské mince Břetislava I., razené ešte za života jeho otca. ${ }^{206}$ Minca sa objavila na mnohých miestach, predovšetkým v Čechách, ale aj ovel'a d'alej, napríklad v okolí Baltského mora. Z toho môžeme usúdit', že prostredníctvom obchodu sa dostala do obehu. Meno VSEBOR, vyrazené na minci, patrí Všeborovi, ktorého spomína Kosmas. ${ }^{207}$ Jeho syn Kojata zastával v časoch Vratislava II. vysokú funkciu na kniežacom dvore. ${ }^{208}$ Hoci tohto Všebora, ak to bol skutočne on, poznáme len cez jeho syna Kojatu, spomínaného v Kosmovej kronike, predsa je pravdepodobné, že sú to prvé dve generácie jedného $\mathrm{z}$ najstarších moravských šlachtických rodov, spomedzi ktorých mohol otec aj razit’ peniaze. Setiech a Všebor svedčia o tom, že panovníci, ak chceli, tak udelili právo razenia peňazí svojim zaslúžilým vel'možom. Razenie a používanie peňazí nemohlo súvisiet's vydelením územia, ale mohlo byt' výsledkom dohovoru medzi panovníkom a členmi jeho rodiny, alebo jeho vel'možmi a vel'mi záviselo od ich vzájomného vzt’ahu, od ich konsenzu.

Jedným z dôležitých poznávacích znakov samostatnej vojvodskej moci a vojvodského výkonu moci, je donácia majetkov vojvodov, prípadne účast' pri donácii súkromných vlastníkov. V 11. storočí vojvodovia darovali majetky dvomi spôsobmi. Bud' konali samostatne, alebo spolu s král’om, prípadne v zhode s ním. Samostatnú donáciu majetku nám dokladá napríklad százdska zakladacia listina. Spomína majetok

\footnotetext{
${ }^{204}$ SUCHODOLSKI, Stanisław: Czy monety palatyna Sieciecha świadczą o jego dążeniu do przyjęcia władzy w Polsce? In: Causa creandi. O pragmatyce źródła historycznego. Ed. Przemysław Wiszewski, Stanisław Rosik, Wrocław : Wydawnictwo Uniwersytetu Wrocławskiego, 2005, s. 368.

${ }^{205}$ SUCHODOLSKI, S.: Czy monety palatyna, s. 371.

206 Pozri CACH, F.: Nejstarší české mince I, č. 300.

${ }^{207}$ Napr. SUCHODOLSKI, S.: Czy monety palatyna, s. 328 (a poznámka č. 15); WIHODA, M.: Morava v době knížecí, s. 127.

${ }^{208}$ ablata est tibi urbis prefectura et data es Koyate, filio Wseboris, qui tunc temporis primus est in palatio ducis. Cosmae Pragensis Chronica Boemorum, Lib. II. c. 19. MGH SRG N. S. 2, s. 111.
} 
zvaný Bubath, ktorý kedysi dostal Peter od vojvodu. ${ }^{209}$ Spomína aj pozemok využívaný na kosenie, ktorý kedysi vlastnil vojvoda. ${ }^{210} \mathrm{~V}$ tejto listine je ešte jedna zmienka o pozemku známom ako vojvodský statok, ktorý župan Peter daroval kláštoru. ${ }^{211}$ Župan Peter daroval okrem toho ešte jeden pozemok, ktorý mu, podl'a jeho vlastných slov, vol'akedy daroval dux Magnus čiže vojvoda Gejza. ${ }^{212}$ Král' a vojvoda však v mnohých prípadoch konali spoločne. Z interpolovanej kópie zakladacej listiny Tihanyského opátstva je zrejmé, že s prevodom majetku musel súhlasit' dux Belo. ${ }^{213}$ Už spomenutý župan Peter sa v százdskej zakladacej listine odvoláva, že majetok Taktaszada, ktorý daroval, mu zanechali spoločne král' Šalamún a dux Gejza. ${ }^{214}$ Spoločný súhlas Ondreja I. a Bela bol potrebný na donáciu časti majetkov palatína Rada pre Pät'kostolské biskupstvo. ${ }^{215}$ Listina pozostáva z dvoch častí, z jednej autentickej a druhej interpolovanej. ${ }^{216}$ Donácia Radových majetkov je v autentickej časti listiny. Môžeme predpokladat', že pri určitých donáciách bolo nutné postupovat' spoločne. $\mathrm{V}$ poslednom prípade to pravdepodobne neboli vlastné majetky vojvodov, ale král'ovské majetkové celky, ktoré kvôli spoločnej vláde museli darovat' obaja spoločne. V už viackrát spomínanej százdskej zakladacej listine donátor žiadal král'a Šalamúna, ako aj vojvodov Gejzu a Ladislava, aby l’ud, žijúci na majetku darovanom kláštoru, oslobodili od platenia desiatku. ${ }^{217}$ Hoci sa v listine jednoznačne píše, že túto žiadost' prijali král' a ostrihomský arcibiskup (quam peticionem rex et archiepiscopus concesserunt), mnohé prezrádza, že svoj súhlas museli dat' aj Gejza a Ladislav. Král'ovský súhlas sa však nevy-

\footnotetext{
209 (okolo 1067): Ad Fonsol fenerie predium, quod vocatur Bubath, dux michi et ego monasterio. DHA I, s. 184, nr. 58.

210 cetera vero in pratis et pascuis in feno secando et in cumulo colligendo, unde dux habuit, inde monasterium permisi habere. DHA I, s. 184, nr. 58. Pozri aj MAKK, Ferenc - THOROCZKAY, Gábor (eds.): Írott források az 1050 - 1116 közötti magyar történelemrôl. (d’alej len ÍFMT) Szeged : Szegedi Középkorász Műhely, 2006, s. 37, pozn. č. 155 (S úvodom, poznámkami a prekladom Ferenca Pitiho).

211 Possessionem in Scenholm, quam dux michi, ego monasterio subdidi. DHA I, s. 183, nr. 58. Pozri aj Ferenc Piti in: ÍFMT, s. 36 (pozn. č. 147).

212 Hanc terram dux Magnus dedit michi et ego monasterio. DHA I, s. 184, nr. 58. Pozri aj Ferenc Piti in: ÍFMT, s. 39 (pozn. č. 178).

${ }^{213}$ Hec omnia ... consilio karissimi fratris nostri Bele duicis contulimus. DHA I, s. 156, nr. 43/2.

214 do territorium, quod postea concessit michi Salomon rex cum Magno duce in villa, qui dicitur Ceda. DHA I, s. 184, nr. 58. Pozri aj Ferenc Piti in: ÍFMT, s. 38 (pozn. č. 162).

215 quomodo ego Rado palatinus licencia piissimi regis Andree eiusque fratris Adalberti invictissimi ducis partem possessionis mee Sancto Petro Quinqueecclesiensi ordinavi. DHA I, s. 161, nr. 46.

216 Pozri príslušný komentár Györgya Györffyho in: DHA I, s. 160.

217 Tandem ego Petrus rogavi regem cum duce Magno et cum duce Ladizlao, ut hii populi decimas non darent. DHA I, s. 185, nr. 58.
} 


\section{Dániel Bagi}

skytuje len v takomto právnom vzt’ahu. S donáciou vojvodu Dávida súhlasil aj svätý Ladislav.218

Nie je možné určit', či samostatné vojvodské majetkové donácie pramenili z panovníckej právomoci, či tvorili súčast' vojvodského majetkového komplexu, alebo či pokrývali súkromné majetky vojvodov. Môžeme si len domysliet', že spolupráca medzi král'mi a vojvodami nezahŕňala v sebe spoločné panovnícke právo na donáciu majetkov. To znamená, že ako vládcovia museli postupovat' vždy spoločne a pri súkromných donáciách mohli konat' samostatne. Ak to tak bolo, systém rozdelenia moci realizovaný Arpádovcami sa skutočne zakladal na spolupráci král'a a vojvodu.

V širokom okruhu stredo- a východoeurópskych dynastií je samostatné právo uhorských vojvodov na donáciu majetkov zvláštnost'ou. U Zbigniewa nepoznáme ani jednu súkromnú alebo vládcovskú donáciu. Len na základe majetkových donácií jeho brata Boleslava III. môžeme predpokladat', že aj on mal na to oprávnenie. Na základe správy Galla Anonyma vieme, že Boleslav pri príležitosti svojho sobáša niektorým (verným) daroval hrady a mestá, iným dediny a statky. ${ }^{219}$ Správu o udalostiach okolo roku 1103 treba prijímat' s náležitou opatrnost'ou. Pol'ský kronikár totiž mienil v hlavnej postave svojho diela oživit' štedrost' Boleslava Vel'kého, teda Boleslava Chrabrého.

U Přemyslovcov je situácia o niečo lepšia, pretože tu máme aspoň niekol'ko listín, ktoré sa zachovali v neskoršom odpise. Benediktínsky kláštor v Hradišti je jedným z najdôležitejších a najvýznamnejších zakladatel'ských činov a jedna z najštedrejších majetkových donácií olomouckého kniežat'a Ota I. (Pekného) a jeho manželky Eufémie. ${ }^{220}$ Ako svedok bol pri založení a obdarovaní prítomný aj jeho brat, v Prahe panujúci Vratislav II. ${ }^{221}$ Avšak treba poznamenat', že k založeniu Otom a jeho manželkou musel prispiet' aj Vratislav. V listine, ktorá vznikla takmer v rovnakom čase, čítame, že bol prítomný pri vysviacke, dal svoj súhlas na založenie a panovníckym dekrétom, prostredníctvom moci nadobudnutej prvenstvom veku a dedičstvom, prispel k majetkovým donáciám Ota a Eufémie. ${ }^{222}$ Aj Vratislav rozmnožil dary pre kláštor. Už L. Bernát Kumorovitz poukázal na podobnost' medzi listinou župana Petra z roku 1067

\footnotetext{
${ }^{218}$ de consensu meo. DHA I, s. 284, nr. 96.

${ }^{219}$ Belliger Bolezlauus dare munera non quievit, ... aliis civitatis, castella, aliis villas et predia. Galli Anonymi chronicae et gesta ducum sive principum Polonorum, Lib. II. c. 23. MPH N. S. 2, s. 90 .

${ }^{220}$ CDM I, s. 162-164, nr. 182. K založeniu hradišt'ského kláštora a jeho vzt'ahom k Uhorsku pozri KOSZTA, L.: A hradištei bencés monostor, s. 403-426.

${ }^{221}$ CDM I, s. 163, nr. 182.

${ }^{222}$ Rogante itaque Ottone nostro videlicet fratre carissimo proprioque germano Moraviae provincie principe, nos, ut eius qua min honore Christi et beati protomartiris Stephani
} 
a zakladacou listinou hradišt'ského kláštora. ${ }^{223} \mathrm{Na}$ základe toho by sme mohli hradištt'skú zakladaciu listinu zaradit' medzi súkromné listiny. České kniežatá vytvorili právo, aby ako panovníci prispievali k súkromným zakladatel'ským činom ich moravských kniežacích príbuzných, ako keby to boli len vel'moži 11 . storočia. ${ }^{224}$ Právo českých kniežat prispievat' k majetkovým donáciám núti k zamysleniu, ako d’aleko siahali takéto právomoci u olomouckých kniežat. Druhá známa donácia moravských Přemyslovcov patrila třebíčskemu benediktínskemu kláštoru, ktorý založili Oldřich a Litold okolo roku 1100. Zakladaciu listinu poznáme jedine z jedného rukopisu Kosmasovej kroniky. ${ }^{225}$ Už Bertold Bretholz, ktorý pripravil kritické vydanie Kosmasovej kroniky, poznamenal, že vo svojich formuláciách je takmer identická so zakladacou listinou hradišt'ského kláštora. ${ }^{226}$ To opät' potvrdzuje platnost' názoru L. Bernáta Kumorovitza, že medzi súkromné listiny napodobňujúce listiny panovníkov patrí aj třebíčska zakladacia listina. Nápadné je, že v tomto prípade sa nestretávame s potvrdením českých kniežat. Dôvod je (možno) v tom, ako to $\mathrm{v}$ známom texte zakladacej listiny čítame, že Litold a Oldřich sa mohli na svoje predtým odobraté majetky vrátit' len po smrti Břetislava II. a kláštor mohli založit' za vlády Bořivoja II. Bořivoj sa však do roku 1103 snažil získat' pol'ský trón a tak je možné, že sa nemohol zaoberat' svojimi brnenskymi a znojemskými príbuznými.

K funkciám spoločného výkonu moci patrili aj vojenské funkcie. György Györffy videl vo vojvodstve v prvom rade oblast' usídlenia pridružených etník prichádzajúcich spolu s Mad’armi. Považoval ho za „nárazníkovú zónu“ a preto mu prisudzoval hlavne vojenské a hranično-obranné funkcie. ${ }^{227}$ Táto predstava sa značne podobá na názor dodnes presadzovaný hlavnou líniou českej a československej historiografie. Podl'a tohto názoru, Přemyslovcami zabraté a pre mladších členov rodiny

erexerat, dedicationi interessemus ecclesie in suburbio Olomuciensis civitatis, consensum prebuimus, ibique cum summa fraternitatis diligentia honorifice suspecti et habiti sumus. Unde eiusa annuentes percibus per hanc, quam a Deo nobis provectiorus etetis et dignitatis hereditarie datam possidemus potestatem, dominii nostro decreto confirmationem abbatie in iam prefata ecclesia, quam ut diximus ipse tam proprio pro remedio anime, quam coniugis sue dilecte Euffemie nominate construxerat, rebusque optime ex propriis ditaverat, statuimus. CDM I, s. 164-165, nr. 183.

${ }^{223}$ KUMOROVITZ, L. Bernát: A középkori „magánjogi” írásbeliség első korszaka, XI-XII. század. In: Századok. roč. 97, č. 1, 1963, s. 3-4 (pozri tiež poznámku č. 16).

${ }^{224}$ Podobný postup vidíme aj v d’alších, sčasti v neskorších falzách zachovaných listinách, napr. v CDB I, s. 351-352, nr. 378, kde Břetislav I. sa podiel'al na istej súkromnej donácii.

${ }^{225}$ Cosmae Pragensis Chronica Boemorum, Anhang IV. MGH SRG N. S. 2, s. 258-261.

${ }^{226}$ Cosmae Pragensis Chronica Boemorum, Anhang IV. MGH SRG N. S. 2, s. 257, pozn. č. 1 a 2, tamže pozri aj staršiu literatúru k listine.

${ }^{227}$ GYÖRFFY, Gy.: A magyar nemzetségtől a vármegyéig, s. 49-50; GYÖRFFY, Gy.: Tanulmányok, s. 39-40. 
udržiavané moravské údelné kniežatstvá boli obrannou zónou Čiech voči Uhorsku. To mohlo zapríčinit' nárast vojenského významu severozápadnej časti Uhorska, kam smerovali útoky Břetislava I. ${ }^{228}$ Neskôr vzniknuté Znojemské kniežatstvo takisto slúžilo na obranu, tentoraz voči Rakúsku. ${ }^{229}$ Gyula Kristó zastával názor, že král’ovské vojvodstvo sa zriadilo na pohraničí arpádovskej monarchie a hralo rozhodujúcu úlohu vo feudalizácii tam unikajúceho slobodného obyvatel'stva, ktoré ešte nebolo podriadené. ${ }^{230}$ Györffy a Kristó nepochybovali o tom, že vojvodstvo mohlo mat' v prvom rade vojenskú funkciu. Zatial'čo Györffy, podobne ako už pred ním János Karácsonyi, ${ }^{231}$ vyzdvihol obranu hraníc, ${ }^{232}$ Kristó postavil do centra vojvodskú moc ako nátlakovú organizáciu, ktorá sa zameriavala na ozbrojené podmanenie ešte nepodriadeného l'udu žijúceho $\mathrm{v}$ okrajovej oblasti král'ovstva. ${ }^{233}$ Od Györgya Györffyho pochádza navyše aj idea, ${ }^{234}$ ktorú si novšie osvojil aj László Koszta,235 že meč, spomínaný v 92. kapitole kronikárskej kompozície zo 14. storočia ${ }^{236} \mathrm{v}$ známom várkonyskom výjave, je jednoznačným dôkazom toho, že vojvodstvo plnilo predovšetkým vojenské, hranično-obranné úlohy. Koszta popri tom označil za úlohu vojvodstva obranu moravského pohraničia. 237 Pri posudzovaní argumentov nemáme dôvod pochybovat' o tom, že král'ovskí vojvodovia vždy vykonávali aj vojenské úlohy. Dokonca mnohé úryvky kronikárskej kompozície zo 14. storočia potvrdzujú, že král' aj vojvoda vždy disponovali vlastným vojskom. ${ }^{238}$ Gesta Galla Anonyma dosvedčujú, že to nebolo charakteristické len pre

\footnotetext{
${ }^{228}$ KRZEMIEŃSKA, B.: Die Rotunde, s. 19.

${ }^{229}$ PROCHÁZKA, R.: Zur Funktion der mährischen Burgen, s. 613-614.

${ }^{230}$ KRISTÓ, Gy.: A XI. századi hercegség, s. 73-85.

${ }^{231}$ KARÁCSONYI, J.: A magyar nemzet áttérése, s. 108.

232 GYÖRFFY, Gy.: A magyar nemzetségtől a vármegyéig, s. 50; GYÖRFFY, Gy.: Tanulmányok, s. 40-41. K jeho úlohe pri obrane hranice pozri aj KARÁCSONYI, J.: A magyar nemzet áttérése, s. 108.

233 Podrobnejšie pozri KRISTÓ, Gy.: A XI. századi hercegség, s. 84-85.

${ }^{234}$ GYÖRFFY, Gy.: A magyar nemzetségtől a vármegyéig, s. 52-53; GYÖRFFY, Gy.: Tanulmányok, s. 40.

235 KOSZTA, L.: A nyitrai püspökség létrejötte, s. 282-284.

${ }^{236}$ Fecitque rex ei coronam iacere ante se super rubeum stramentum et gladium iuxta, qui ducatum designat. Chronici Hungarici compositio saeculi XIV., c. 92. SRH I, s. 354.

${ }^{237}$ KOSZTA, L.: A nyitrai püspökség létrejötte, s. 282-284. V staršej literatúre pozri GYÖRFFY, Gy.: A magyar nemzetségtől a vármegyéig, s. 52-53; GYÖRFFY, Gy.: Tanulmányok, s. 40.

${ }^{238}$ Bez nároku na úplnost' napr.: Rex autem et dux secunda feria transierunt Zauam et mane facto ordinaverunt acies suas et plenis manipulis suis universaliter per turmas suas insertis umbonibus obsederunt civitatem. Chronici Hungarici compositio saeculi XIV., c. 106. SRH I, s. 371-372. Vyd autem dicebat: 'Statim ut exercitum nostrum viderent, fugient.' Sed et duces summo mane suas acies ordinaverunt. Chronici Hungarici compositio saeculi XIV., c. 121. SRH I, s. 387.
} 
Nové možnosti prístupu k výskumu dejín vojvodstva v 11. storočí

Arpádovcov. Počas rozdelenia piastovskej monarchie v roku 1097 sa Vladislava Hermana opýtali jeho vel'moži, ktorému synovi určil väčšiu úlohu v spravovaní štátu a tým aj vo zvolávaní armády. Knieža vo vojenskej oblasti rátal s obidvomi synmi, rozdelenie krajiny teda rozdel'ovalo aj vojenské funkcie. ${ }^{239}$ Tento záznam Galla Anonyma je len nepriamym dokladom o vojenskej situácii v Pol'sku. Pol'ský kronikár zaznamenal predovšetkým to, že Zbigniew bol od začiatku neschopný a to aj na vykonávanie vojenských úloh. Dokonca aj iné záznamy Galla Anonyma potvrdzujú, že vojenské velenie Zbigniewovi patrilo. Ten však svoju vojenskú silu nepoužil na boj proti nepriatel'om, ale na pustošenie otcovského dedičstva. ${ }^{240}$ Iné miesta v kronike predsa len poukazujú na to, že v období do smrti Vladislava Hermana, ked' si moc delili otec a dvaja synovia, všetci traja mali vlastné vojsko. Boleslav aj napriek tomu, že ešte nebol opásaný mečom. ${ }^{241}$ Je taktiež nesporné, že vojakov mali aj moravské kniežatá. Už skorší výskum si všimol,242 že Boleslav Chrabrý počas vojen s ríšou disponoval aj moravskými bojovníkmi. ${ }^{243}$ Aj neskoršie pramene svedčia, že moravské kniežatá neboli bez samostatnej vojenskej sily. ${ }^{244}$ Dobrým príkladom je prítomnost' kniežat'a Ota a jeho vojska v bitke pri Mogyoróde. ${ }^{245}$ Tieto príbehy však môžu poskytnút' ešte jeden poznatok. Vojenské úlohy, nadobudnuté pri delení moci sa pravdepodobne nepovažovali za zvláštnost', ale boli prirodzeným sprievodným javom výkonu moci. Navyše môžeme predpokladat', že tak ako v Uhorsku, tak aj v Pol'sku a Čechách všetci členovia rodiny, ktorí sa dostali k moci, mali aj vojenské úlohy. To, podl'a nášho názoru, zodpovedá predstavám o moci z 11. storočia v zmysle chápania sveta ako funkčných stavov. To znamená, že panovnícke úlohy so sebou automaticky priniesli aj výkon vojenských

\footnotetext{
${ }^{239}$ Interrogatus autem pater a principibus, quis eorum excellencius emineret in legacionibus mittendis et suscipiendis, in exercitus convocando et conducendo et in tanti regni dispensacione multimoda... Galli Anonymi chronicae et gesta ducum sive principum Polonorum, Lib. II. c. 8. MPH N. S. 2, s. 74.

240 Zbigneuus fratri suo laboranti nec invitatus auxilium impendebat, insuper etiam cum hostibus fratris occulte fedus et amiciciam coniungebat et pecuniam illis pro militibus in subsidium transmittebat. Galli Anonymi chronicae et gesta ducum sive principum Polonorum, Lib. II. c. 24. MPH N. S. 2, s. 91.

${ }^{241}$ Zbigneuus ... cum exercitu patris atque suo contra Pomoranos sine fratre parvulo properavit, minusque tamen laudis maior cum multus antecendens, quam iunior frater cum paucis subsequens, acquisivit. Galli Anonymi chronicae et gesta ducum sive principum Polonorum, Lib. II. c. 17. MPH N. S. 2, s. 84-85.

242 Pozri KRZEMIEŃSKA, B.: Die Rotunde, s. 31.

${ }^{243}$ Interea Mararenses Bolezlavi milites magnam Bawariorum cataveram dolo circumvenientes incautam occidunt... Thietmari Merseburgensis episcopi Chronicon, VII. 57. (42). MGH SRG N. S. 9, s. 470.

${ }^{244}$ Cosmae Pragensis Chronica Boemorum, Lib. II. c. 35. MGH SRG N. S. 2, s. 132. Pozri aj s d’alšou literatúrou KRZEMIEŃSKA, B.: Die Rotunde, s. 31 a poznámka č. 113.

${ }^{245}$ Chronici Hungarici compositio saeculi XIV., c. 121. SRH I, s. 390.
} 
funkcií, dokonca panovníci museli vo všeobecnosti mat' aj vojenské schopnosti. ${ }^{246} \mathrm{~V}$ tejto súvislosti je samozrejmé, že sa spoluvládcovia a vlastníci jednotlivých oblastí, postarali aj o obranu hraníc, bránili sa pred vpádmi. Proti vyslovene hranično-obrannej funkcii vojvodstva hovorí aj to, že sa s ňou nestretávame na západnom pohraničí. Významnejšie západné pohraničné hrady, napríklad Bratislava a Mošon, ostali v Šalamúnových rukách až do jeho definitívneho vyhnania. Sem sa stiahol po porážke v bitke pri Mogyoróde.

Inou otázkou je, či je prijatel'ná teória, podl’a ktorej je meč symbolom moci vojvodskej a vojvodstva, a koruna král'ovskej moci. Príbeh koruny a meča, ktorý poznáme z 92. kapitoly kronikárskej kompozície zo 14. storočia, sa hlboko integroval do mad'arského historického vedomia. Ondrej I., ktorý proti Belovi podporoval nástupníctvo svojho syna Šalamúna, dal povolat' brata do svojej várkonyskej kúrie, aby dospeli k dohode. Položil pred seba korunu a meč, následne vysvetlil svojim l'ud'om, že chce dat' vojvodovi na výber. Ak si vyberie meč, nech odchádza v mieri, ak korunu, potom nech mu tým istým mečom odseknú hlavu. Belovi pri vchode pošepkali, že ak chce žit', nech si vyberie meč. A on zo strachu, nie dobrovol'ne, tak aj urobil. ${ }^{247}$ Avšak o výklade, čase vzniku kapitoly kroniky, teda textových úsekov zachytávajúcich takzvaný várkonyský výjav, neexistuje medzi mad'arskými bádatel'mi konsenzus. Gyula Kristó akceptoval názor staršieho literárnohistorického bádania, ktoré interpretovalo várkonyský výjav v prvom rade ako epický, prípadne l'udový príbeh. Domnieval sa, že výber medzi dobrom a zlom v úryvku kroniky ${ }^{248}$ je odrazom akéhosi kompromisu, ktorý nemohol vzniknút' skôr než v dobe Kolomana. ${ }^{249} \mathrm{~J}$. Lajos Csóka v ňom videl vsuvku z 12 . storočia a považoval ho za odraz pojmu koruny, vyjadreného v Hartvikovej legende. ${ }^{250}$ Oproti

\footnotetext{
${ }^{246}$ Napr. strenui militis et boni imperatoris officia simul exeguebatur. THORPE, Benjamin (ed.): Florentii Wigorniensis Monachi Chronicon ex chronicis. Tomus I. London : English Historical Society, 1848, s. 175.

247 Volo attemptare ducem et in duobus interrogare, si vult habere coronam vel ducatum." Fecitque rex ei coronam iacere ante se super rubeum stramentum et gladium iuxta, qui ducatum designat. "Si ducatum dux cum bona pace habere voluerit, habeat; si vero coronam, statim vos duo principes surgite et eodem gladio ducem Belam decollate. ... Putabat enim [Andreas] de eadem simplicitate [Belam] dedisse coronam filio suo, sicut sibi Leuente dederat. Chronici Hungarici compositio saeculi XIV., c. 92. SRH I, s. 354-355.

${ }^{248}$ ARANY, János: Naiv eposzunk. In: Arany János összes müvei X. Szerk. Keresztury Mária, Budapest : Akadémiai Kiadó, 1962, s. 264-274; KARDOS, Tibor: Középkori kultúra, középkori költészet. A magyar irodalom keletkezése. Budapest : Magyar Történelmi Társulat, 1941, s. 101.

${ }^{249}$ KRISTÓ, Gyula: XI-XIII. századi epikánk és az Árpád-kori írásos hagyomány. In: KRISTÓ, Gyula: Tanulmányok az Árpád-korról. Budapest : Magvető, 1983, s. 340-343. Pozri aj KRISTÓ, Gy.: Legitimitás, s. 596-597.

${ }^{250}$ CSÓKA, J. Lajos: A latin nyelvü történeti irodalom kialakulása Magyarországon a XI-XIV. században. Budapest : Akadémiai Kiadó, 1967, s. 419.
} 
predstavám Kristóa považoval József Gerics 92. kapitolu za súčast' kronikárskeho konštruktu z obdobia Šalamúna. ${ }^{251}$ Zoltán Tóth, využijúc aj svoje skoršie výskumy, ${ }^{252}$ preukázal použitie anglosaského DunstanEgbertovho (korunovačného) poriadku v 11. storočí, v ktorom sa meč nerátal medzi odznaky král'ovskej inaugurácie. Ked’že v Uhorsku v dobe Kolomana meč bol už znakom král'ovskej hodnosti a po roku 1074 nosili vojvodovia dokázatel'ne vojvodské koruny, zaujal Gerics stanovisko, že „musíme rátat' s takou fázou panovníckych odznakov v našich dejinách, v ktorej nepochybne bolo platné znázornenie vzt’ahu vojvodských a král'ovských znakov v 92. kapitole“.253

Nemôže byt' pochýb o správnosti konštatovania Józsefa Gericsa. Vo vol'be medzi korunou a mečom sotva môžeme vidiet' len epické symboly a len t’ažko môžeme verit', že je to iba l'udový motív výberu medzi dobrom a zlom. Príbeh musel zodpovedat' dobovej verejnej mienke a právnemu poriadku. Samozrejme, otázkou je, čo pod tým rozumieme. Vysvetlit' samostatný meč môže názor historiografie, spomenutý už v prvej časti tejto práce, že vojvodstvo malo v prvom rade hranično-obranné a všeobecné vojenské funkcie a vojvoda bol vždy predovšetkým vojenskou oporou král'ovskej moci. ${ }^{254} \mathrm{Na}$ tomto mieste opät' pripomíname, že král'ovskí vojvodovia vždy vykonávali aj vojenské úlohy. Avšak výkon moci býval vo všeobecnosti spätý s vojenskými úlohami a tak bol zjavne aj panovníckou úlohou. Pre to všetko je potrebné dôkladnejšie preskúmat' otázku, či mohol byt' meč samostatným odznakom moci, a ak áno, v akom zmysle.

Meč (pod názvami gladius, spata alebo ensis) bol neodmyslitel'ným doplnkom panovníckeho odevu. ${ }^{255}$ Spolu s korunou a žezlom bol vlastníctvom panovníka a v tomto význame patril do rodinného dedičstva. Tak to bolo aj predtým, než by sa meč dostal do korunovačných poriadkov. Koruna a ostatné korunovačné insígnie a odevy mali rovnaký osud. Bolo možné ich získat' v súlade so závetom panovníka. Už aj z 9. storočia máme údaje, že panovníci sa v závete dopredu postarali o dedenie

\footnotetext{
${ }^{251}$ GERICS, J.: Legkorábbi gesta-szerkesztéseink, s. 83.

${ }^{252}$ TÓTH, Zoltán: Attila's Schwert. Studie über die Herkunft des sogenannten Säbels Karls des Großen in Wien. Budapest : Magyar Tudományos Akadémia, 1930, s. 130-131; Pozri aj TÓTH, Zoltán: Gladius divinitus ornatus (Megjegyzések a német koronázási formula keltéhez). In: Századok. roč. 67, 1933, 485-487.

${ }^{253}$ GERICS, József: A magyarországi királykoronázás szertartásáról az 1050 -es években. In: GERICS, József: Egyház, állam és gondolkodás Magyarországon a középkorban. Budapest : METEM, 1995, s. 127-128.

254 GYÖRFFY, Gy.: A magyar nemzetségtől a vármegyéig, s. 52-53; KRISTÓ, Gy.: A XI. századi hercegség, s. 84-85. Posledne: KOSZTA, L.: A nyitrai püspökség létrejötte, s. 282-284.

$255 \mathrm{~V}$ tomto duchu sa vyjadril aj Einhard v už citovanom Živote Karola Vel'kého: et gladio semper accinctus. HOLDER-EGGER, Oswald (ed.): Einhardi Vita Karoli Magni, c. 23. MGH SRG 25. Hannover - Leipzig : Hahnsche Buchhandlung, 1911, s. 28.
} 


\section{Dániel Bagi}

svojich osobných predmetov, napríklad aj meča. Karol Vel'ký sa ešte vo svojom závete, známom z Einhardovho životopisného diela, len všeobecne rozhodol o tom, že majú jeho osobné predmety rozdat' alebo predat'. ${ }^{256}$ L'udovít Pobožný však už vo svojom závete konkrétne nariadil, aby jeho korunu a meč zdedil Lotar. ${ }^{257}$ Dôkazom toho, že to nebolo len prosté rozdelenie rodinného vlastníctva, ale prenesenie moci prostredníctvom týchto odznakov je, že panovník nariadil, aby spísali král'ovské ozdoby čiže koruny, zbrane, nádoby a iné predmety nachádzajúce sa $\mathrm{v}$ pokladnici. ${ }^{258} \mathrm{Z}$ nich si vybral mocenské odznaky, korunu a meč, ktoré mali poslat' Lotarovi. Obraz o L'udovítovi Pobožnom, ktorý vykreslil autor spisu, je zrejme zaujatý, samozrejme môže byt' aj zveličený, ved' podl'a Fuldských letopisov, ktoré takisto informujú o cisárovom testamente, došlo len k odovzdaniu koruny a žezla. ${ }^{259}$ Avšak po smrti cisára a franského král'a Karola Vel'kého, počnúc najneskôr L'udovítom Pobožným, boli koruna a meč odovzdávané spoločne. Po smrti Karola Lysého v roku 877 jeho manželka Richilda poslala následníkovi trónu L’udovítovi II. (Koktavému) predmety potrebné na král'ovskú korunováciu, medzi nimi korunu a meč a odovzdala mu príkaz jeho otca, čiže jeho závet. 260 Po smrti L’udovíta Pobožného aj v závete jeho najmladšieho syna bol medzi odznakmi výkonu moci opät' meč. Nie jasné, či to súvisí s tým, že L’udovít Pobožný v spojitosti s odovzdaním panovníckych odznakov synovi Lotarovi ho zaviazal, aby rešpektoval práva syna Karola Lysého, ktorého

\footnotetext{
${ }^{256}$ Einhardi Vita Karoli Magni, c. 33. MGH SRG 25, s. 39. Pozri aj RÖCKELEIN, Hedwig: Das Schwert als Zeichen von Macht und Herrschaft in Text-, Bild- und Sachzeugnissen der Karolingerzeit. Magisterarbeit zur Erlangung der Würde des Magister Artium der Philosophischen Fakultäten der Albert-Ludwigs-Universität zu Freiburg, 1981, Manuskript, passim; KÖRNTGEN, Ludger: Königsherrschaft und Gottes Gnade. Zu Kontext und Funktion sakraler Vorstellungen in Historiographie und Bildzeugnissen der ottonisch-frühsalischer Zeit. Berlin : De Gruyter, 2001, s. 220-228.

${ }^{257}$ Et Hlotario quidem coronam, ensem auro gemmisque redimitum eo tenore habendum misit. TREMP, Ernst (ed.): Astronomus, Vita Hludowici imperatoris, c. 63. MGH SRG 64. Hannover : Hahnsche Buchhandlung, 1995, s. 548.

258 et rem familiarem, que constabat in ornamentis regalibus, scilicet coronis et armis, vasis, libris vestibusque sacerdotalibus, per singula describi iuberet. Astronomus, Vita Hludowici imperatoris, c. 63. MGH SRG 64, s. 548.

${ }^{259}$ Hunc enim ferunt imperatorem morientem designasse, ut post se regni gubernacula susciperet, missis et insigniis regalibus, hoc est sceptro imperii et corona. KURZE, Friedrich (ed.): Annales Fuldenses sive annales regni Francorum orientalis, a. A. 840. MGH SRG 7. Hannover : Hahnsche Buchhandlung, 1891, s. 31.

${ }^{260}$ Richildis ... ad Hlodowicum veniens ... attulit ei praeceptum, per quod pater suus illi regnum ante mortem suam tradiderat, et spatam, qaue vocatur Sancti Petri, per quam eum de regno revestiret, sed et regium vestimentum et coronam ac fustem. WAITZ, Georg (ed.): Annales Bertiniani, a. A. 877. MGH SRG 5. Hannover : Hahnsche Buch handlung, 1883, s. 137-138.
} 
mal s poslednou manželkou Juditou. ${ }^{261} \mathrm{~V}$ každom prípade po smrti L'udovíta Koktavého meč a koruna boli opät' spolu medzi mocenskými odznakmi nasledujúceho panovníka. To môže opät' potvrdzovat', že správa v životopise L’udovíta Pobožného je pravdivá. ${ }^{262}$ Spoločné odovzdávanie koruny a meča vybranému dedičovi trónu sa však neobjavilo len v karolovskej dynastii. Aj omnoho neskoršia udalost', ktorá sa stala $\mathrm{v}$ posledných desat'ročiach 11 . storočia, poukazuje na to, že koruna a meč spoločne zohrávali úlohu pri dedení trónu. Gesta Normannorum Ducum, napísané Viliamom z Jumièges, zachovávajú závet pripisovaný Viliamovi Dobyvatel'ovi, v ktorom panovník pred svojou smrt'ou rozdelil ríšu medzi svojich synov. Viliamovi II. (Ryšavému) zanechal Anglicko, jeho normandské majetky zdedil Róbert a svojho tretieho syna Henricha, ktorý sa napokon po smrti Viliama II. dostal k moci, uspokojil 5 000 librami. Podl'a svedectva závetu zdedil panovnícke odznaky, teda korunu, meč a žezlo Viliam. ${ }^{263}$ Text nie je bez problémov. Výskum preukázal, že s malou výnimkou sa zakladá na takmer doslovnom prevzatí vyššie citovaného závetu L’udovíta Pobožného a závetu v Einhardovom životopise Karola Vel'kého. ${ }^{264}$ Údajný závet mohol vzniknút' okolo roku 1097, ako výsledok sporu medzi Viliamom II. (Ryšavým) a jeho bratom Róbertom, ktorý zdedil Normandské a Mainské vojvodstvo. Text jednoznačne slúžil na to, aby Viliam II. predstavil poslednú vôl'u svojho otca z takého pohl'adu, ako keby jemu prislúchali všetky odznaky král'ovskej moci, a jeho bratovi len vojvodstvo. Ked'že normandské elity protestovali proti rozdeleniu území, Viliam II. preniesol zodpovednost' na svojho otca za to, že kontinentálne a anglické normanské majetky neostali v jedných rukách. ${ }^{265}$

Koruna a meč sa teda podl'a zvyklostí dedili v jedných rukách. Pri poznaní toho všetkého je vhodné bližšie preskúmat', v akých prípadoch

\footnotetext{
${ }^{261}$ Astronomus, Vita Hludowici imperatoris, c. 63. MGH SRG 64, s. 548.

262 et sentiens se mortem evadere non posse, per Odonem ... et Album ... coronam et spatam ac reliquum regium apparatum filio suo Hludowico misit, mandans illis qui cum eo erant, ut eum in regem sacrari ac coronari facerent. Annales Bertiniani, a. A. 879. MGH SRG 5, s. 148. 263 et Willelmo quidem, suo filio, coronam, ensem, sceptrum ... habendum permisit. HOUTS VAN, Elisabeth (ed.): The Gesta Normannorum Ducum of William of Jumièges, Orderic Vitalis and Robert of Torigni, Vol. 2. Oxford : Clarendon Press, 1995, s. 186. Ku kritickému vydaniu De obitu Willelmi pozri tiež: LACK, Katherine: The De Obitu Willelmi: Propaganda for the Anglo-Norman Succession, 1087-88? In: English Historical Review. roč. 123, č. 505, 2008, s. 1445-1456.

${ }^{264}$ GILLINGHAM, John: At the Deathbed of the Kings of England. In: Herrscher- und Fürstentestamente im westeuropäischen Mittelalter. Hg. von Brigitte Kasten, Köln - Weimar - Wien : Böhlau, 2008, s. 523, 525 a poznámka 73. Súhrnne pozri aj: LACK, K.: The De Obitu Willelmi, s. 1445-1449.
}

${ }^{265}$ LACK, K.: The De Obitu Willelmi, s. 1439. 
a v akej dobe sa objavuje meč samostatne, teda bez koruny. ${ }^{266}$ Podl'a Galla Anonyma Boleslav, vzoprúc sa zvyklostiam, už po mnohýkrát Zbigniewovi odpustil a vpustil ho spät' do krajiny. Avšak Zbigniew sa nevrátil skromne, ako miles, ale $\mathrm{s}$ „vytaseným mečom“. To znamená v spoločnosti muzikantov, v sprievode trubačov a pred sebou nechal niest' meč (ense praecedente), ukazujúc, že prišiel vládnut' a nie slúžit'. ${ }^{267}$ To bolo poslednou kvapkou, ktorou pretiekol pohár trpezlivosti. Nasledovalo oslepenie a definitívne odstránenie Zbigniewa. Tento príchod sa mal udiat' opačne. Správne by Boleslav vchádzal do mesta v súlade $\mathrm{s}$ pravidlami adventus regis, imitujúcimi príchod Ježiša do Jeruzalema a jeho meč by niesol niekto iný, v tomto prípade zrejme Zbigniew. Hoci z 12. storočia poznáme mnoho podobných príkladov, ${ }^{268} \mathrm{z}$ čoho by sme mohli usúdit', že symbol nosenia meča môže súvisiet' s premenou západoeurópskej spoločnosti a myslenia v 12. storočí. Podobné prípady poznáme aj z ovel'a skorších čias. Dudo zo Saint-Quentin zaznamenal stretnutie západofranského král'a L'udovíta IV. Zámorského s jeho švagrom, rímskonemeckým král’om a cisárom Otom I. (ktorého Dudo nesprávne menuje Henrich). ${ }^{269}$ Podl'a Duda L'udovít IV. Zámorský požiadal Ota o vojenskú pomoc. On však bol ochotný rokovat' s ním len vtedy, ak medzi nimi bude sprostredkovatel'om jeho starý priatel', normandský vojvoda Viliam I. Dlhý meč, syn Rolla, zakladatel'a normanskej dynastie. V súlade s dohodou poslal normandský vojvoda Otovi vyslanca. Oto dal svoj súhlas na stretnutie a poslal k Viliamovi svojho dôverníka menom Cono. Cono spolu s Viliamom prichádzali do Visé na stretnutie západofranského a saského panovníka. Cono nielen ohlásil príchod normandského

\footnotetext{
${ }^{266}$ Medzi príkladmi neuvádzame príbeh, ktorý zachoval kronikár Lampert z Hersfeldu, podl’a ktorého matka král’a Šalamúna darovala Otovi z Nordheimu meč pripisovaný Atilovi. $\mathrm{V}$ tomto prípade išlo, ako sme to krátko spomenuli už aj vyššie, o dar, teda dvorskú reprezentáciu. Pozri ZSOLDOS, Attila: Az Árpádok és asszonyaik. A királynéi intézmény az Árpádok korában. Budapest : MTA Történettudományi Intézete, 2005, s. 128. Text pozri Gábor Thoroczkay in: ÍFMT, s. 106-107 a poznámka 584. K textu Lamperta z Hersfeldu pozri aj VESZPRÉMY, László: A magyarországi hun hagyomány legkorábbi írott forrásai és európai kapcsolatuk. In: Acta Universitatis Szegediensis. Acta Historica 135. 2013, s. 29-30.

${ }^{267}$ non se serviturum sed regnaturum designabat. Galli Anonymi chronicae et gesta ducum sive principum Polonorum, c. 25. MPH N. S. 2, s. 155.

268 Takýto prípad je známy práve z pol'ských dejín zo začiatku 12. storočia: Magdeburské anály zaznamenali, že roku 1135 Boleslav III., z ktorého sa stal miles, sám niesol v Merseburgu meč cisára Lothara III., ked' po dlhých bojoch napokon uznal ríšsku zvrchovanost'. Bolizlaus vero post sacramenta in die sancto manibus applicatis miles eius efficitur, et cesari ad ecclesiam processuro, gladium illius ante ipsum portavit. Pozri Annales Magdeburgenses, a. A. 1135. MGH SS 20, s. 185. K pasáži z prameňa pozri DALEWSKI, Zbigniew: Ritual and Politics. Writing the History of a Dynastic Conflict in Medieval Poland. Leiden - Boston : Brill, 2008, s. 17.

${ }^{269}$ LAIR, Jules (ed.): Dudo de Saint Quentin: De moribus et actis primorum Normanniae ducum, c. 52. Caen : Typ. F. Le Blanc-Hardel, Imprimeur-Libraire, 1865, s. 194-197.
} 
vojvodu, ale niesol aj jeho meč, čím chcel vyjadrit’ vládcovskú vel'kost' Viliama. ${ }^{270}$ Okrem správy Duda zo Saint-Quentin poznáme mnoho iných prípadov, ktoré sa udiali ešte pred 12. storočím. Thietmar Merseburský zapísal príbeh Anfrida (neskoršieho utrechtského biskupa svätého Anfrida). Anfrid v mladom veku, po tom, čo ho dali na vojenskú službu, nosil meč Ota I. pri jeho príchode do Ríma. ${ }^{271} \mathrm{~V}$ tomto prípade kládol Thietmar vel'ký dôraz na dôverný vzt'ah medzi Otom a Anfridom. Anfrid mohol túto úlohu dostat' len vd'aka vel'kej dôvere, ktorú k nemu Oto prechovával. Podl'a inej správy merseburského biskupa, pol'ský knieža Boleslav Chrabrý, ktorý sa chcel zmierit’ s cisárom Henrichom II., stal sa cisárovým miles-om a idúc v jeho sprievode, sám nosil cisársky meč. ${ }^{272}$ Symbolický význam nosenia meča teda spočíval v tom, že vyjadroval moc a vôlu panovníka vládnut'. Ten, kto nosil jeho meč, sa podriadil jeho moci.

Popri nosení meča však poznáme aj iné príklady samostatného meča, ktoré sú pre porovnanie s várkonyským výjavom významné. Už vyššie spomínaný príbeh Duda zo Saint-Quentin totiž nekončil príchodom Viliama Dlhého meča. Lotrincov a Sasov dráždil príchod Viliama, preto sa posmešne spýtali Cona, akým úžasným nadaním a mocou disponuje normanský vojvoda, ktorý sa dostavil pokrytý zlatom, no iba s 500 vojakmi? ${ }^{273}$ Urážku ešte Viliam prehltol, ale jeho vojaci nie a na druhý deň, bez vedomia ich pána prešli do tábora Sasov, kde sa pustili do pustošenia príbytkov Otovho vojska. Viliam, aby zabrzdil súkromnú akciu svojich vlastných l'udí, požiadal Cona, ktorý ho o udalostiach informoval, aby vzal jeho meč a ukázal ho vojakom. Vojaci nato v tichosti opustili saský tábor. ${ }^{274}$ Práve táto udalost' sa ponúka ako možná príčina prezývky Dlhý meč, ktorú normandský vojvoda Viliam I. mal. ${ }^{275}$ Bližšie k pravde však

\footnotetext{
${ }^{270}$ Dudo de Saint Quentin, De moribus et actis primorum Normanniae ducum, c. 52, s. 197. ${ }^{271}$ Romam sane predicto cesare ingrediente, non minimum confisus in iuvene fecit eum spataferium suum. Thietmari Merseburgensis episcopi Chronicon, IV. 32. MGH SRG N. S. 9, s. 169.

272 et post sacramenta regi ad ecclesiam ornato incedenti armiger habetur. Thietmari Merseburgensis episcopi Chronicon, VI. 91. MGH SRG N. S. 9, s. 382.

${ }^{273}$ Lotharienses et Saxones coeperunt invective et ironice alloqui Cononem, dicentes: Quam mirae sufficientiae et potestatis est dux ... qui huc advenit auro computus et ornatus cum militibus quingentis? Dudo de Saint-Quentin, De moribus et actis primorum Normanniae ducum, s. 197.

${ }^{274}$ Tunc Willelmus ensem ... dedit Cononi, ut indicio exeundi deferret eum et ostenderet legioni domibus residenti domosque adhuc dissipanti. Quum autem Cono iterum festinans illis occurreret, ensemque Willelmi ducis ... illis demonstraret, continuo non modo adquiescunt, verum summissio voltu proclivi contra ensem, domos dimiserunt, seseque nimium in exitu opprimentes, sine murmure ad suum ducem reverterunt. Dudo de Saint-Quentin, De moribus et actis primorum Normanniae ducum, s. 197.

${ }^{275}$ SHOPKOW, Leah: The Carolingian World of Dudo de Saint Quentin. In: Journal of Medieval History 15. 1989, s. 32-33.
} 
môže byt' to, že Cono konal v službe panovníka a v tomto postavení niesol a ukázal Viliamov meč. ${ }^{276}$

Napokon o tom, že meč jasne vyjadroval aj rozdiel v postavení medzi dvomi stranami, máme názorný príbeh z pera Richera z Reims. Podl'a neho sa rímskonemecký cisár Oto II. a vojvoda Hugo Kapet stretli, aby viedli rokovania. Pred rokovaním poslal Oto všetkých von zo siene a svoj meč položil na stoličku. Na konci rozhovoru vstal, meč tam zanechal a požiadal Huga, aby sa vrátil a doniesol mu ho. Tým dal jasné znamenie pre prítomných, že Hugo sa stal Otovým vazalom. Symbolickú silu gesta najlepšie pochopil orleánsky biskup sprevádzajúci vojvodu Huga ako tlmočník. Biskup ihned’ vytrhol meč z Hugových rúk a sám ho odniesol za Otom. ${ }^{277}$

Ak sa vrátime $\mathrm{k}$ protikladnému postaveniu koruny a meča v 92. kapitole kroniky, tak ani zd'aleka nemáme istotu, že tento protiklad vyplýva len z korunovačného poriadku. Takisto je otázne, či meč symbolizuje len vojenské úlohy. Vyššie uvedené príklady objasňujú, že od doby Karolovcov, kedy sa meč ešte ani neobjavil v korunovačnom poriadku, rozhodovali panovníci o korune, meči a ostatných odznakoch a tiež o odeve ako o súčasti rodinného vlastníctva. Bez delenia ich zanechali jedinej osobe. Samostatný meč bol symbolom podriadenosti. Nepochybujúc o uplatnení Dunstan-Egbertovho (korunovačného) poriadku pri Šalamúnovej korunovácii, ${ }^{278}$ máme vážne podozrenie, že to bol dobre naplánovaný teatrálny výjav, ktorý sa začína stretnutím dvoch rovnocenných členov rodiny a končí uznaním panovníka a odchodom vazala. Ako pri vyššie uvedených prípadoch, tak aj pri várkonyskom výjave vôbec nie je isté, že to boli udalosti, ktoré sa skutočne stali. Z príbehu sa vynára skôr taký

\footnotetext{
${ }^{276}$ KAMP, Hermann: Die Macht der Zeichen und Gesten. Öffentliches Verhalten bei Dudo von Saint-Quentin. In: Formen und Funktionen öffentlicher Kommunikation im Mittelalter. ed. Gerd Althoff, Stuttgart : Jan Thorbecke, 2001, s. 135.

277 Otto gloriam sibi parare cupiens, ex industria ęgit, ut omnibus a cubiculo regio emissis, eius gladius super sellam plectilem deponeretur. Dux etiam solus cum solo episcopo introduceretur, ut rege Latiariter loquente, episcopus Latinitatis interpres, duci quicquid diceretur indicaret. Introgressi igitur a rege ingenti favore excepti sunt. Rex iniuriarum querelam deponit. Et osculum dans, gratiam sui favoraliter amico impertit. Post multa colloquia de amicicia habenda, cum rex exiret, gladiumque respiciens peteret, dux paululum a se discedens se inclinavit ut gladium tolleret, ac post regem ferret. Hac enim causa super sellam relictus fuit, ut dum dux cuntis videntibus gladium ferret, in posterum etiam se militaturum indicaret. Episcopus vero duci consulens, gladium ab eius manu rapuit, et ipse deferens post regem incessit. HOFFMANN, Hartmut (ed.): Richeri historiarum libri IIII, Lib. III. c. 84-85. MGH SS 38. Hannover : Hahnsche Buchhandlung, 2000, s. 217-218.

${ }^{278}$ LASZLOVSZKY, József: Angolszász koronázási ordo Magyarországon. In: Bárány, Attila - Laszlovszky, József - Papp, Zsuzsanna: Angol-magyar kapcsolatok a középkorban I. Máriabesnyő : Attraktor, 2008, s. 109-110, vzniesol vo vzt'ahu k existencii a využitiu tohto korunovačného poriadku v Uhorsku pochybnosti, resp. pripustil prevzatie len istých jeho prvkov.
} 
systém argumentov, ktorý zostavili pre málopočetné, vybrané obecenstvo, schopné pochopit' aj jeho symbolické prvky, prípadne ich prekrútený, miestami groteskný spôsob vyjadrenia. Je pravdepodobné, že príbeh o korune a meči v nám známej podobe vznikol neskôr, až po úplynutí Šalamúnovej vlády. Pokúsil sa postavit' argumentáciu o skoršom odklone od pôvodnej rodinnej dohody, zahrnutej v 88. kapitole kroniky. Tento pokus však nebol platný. Hned' totiž udrie do očí, že Belo sa chopí meča len z donútenia, čiže podriadenost' požadovanú jeho bratom nepovažuje za platnú. Služba vynútená zneužitím tiesne alebo neznalosti druhého, prípadne podvodom, ako to zachytila aj humorná zápletka Huga Kapeta s Otom II., známa z pera Richera, bola v očiach tých, ktorí poznali symboly a vedeli o podrobnostiach daného prípadu, neoprávnená. Preto vystúpili proti nej, ako to dokazuje aj zákrok orleánskeho biskupa.

Koruna a meč vo Várkonyi teda nie je protikladným postavením symboliky dvoch „štátov“, ale omnoho viac hovorí o tom, akým spôsobom sa Ondrej snažil podriadit' si Bela a prečo to bolo pre vojvodu neprijatel'né. Príbeh sa tematicky hodí skôr do ret'azca udalostí, na konci ktorého bol Álmoš podriadený pod múrmi Abaújváru v roku 1106.

\section{IV.}

Prichádzajúc k zhrnutiu, pri návrate k otázke, čím bolo vojvodstvo, môžeme konštatovat' nasledovné.

Arpádovský systém delenia moci v 11. storočí nemôžeme považovat' ani za model vývoja štátu, ani za jednoduché uplatnenie dynastického dedičského alebo rodinného práva. Prvý z týchto dvoch názorov sa osobitým spôsobom usiloval adaptovat' teórie postavené na prameňoch a českej historiografickej tradícii na uhorské pomery a druhý premietal pomery z obdobia Viedenského kongresu spätne do stredoveku.

Namiesto výskumu rozvoja štátu je vhodnejšie vychádzat’ z dobového chápania práva a usporiadania spoločnosti, obsiahnutého v prvom rade $\mathrm{v}$ rozprávacích prameňoch, a doň zasadit' dejiny vojvodstva. Základom tohto poriadku bol v prvom rade systém vzt’ahov medzi slobodnými, ktorý spočíval na priatel'stve potvrdenom prísahou. Úpadok amicitie však znemožnil predchádzajúcu spoluprácu založenú na rovnosti a konsenze, a nevyhnutne viedol ku konfliktom.

Môžeme sa domnievat', že tieto medzil'udské vzt'ahy určovali aj pôsobnost' vojvodstva a vojvodov. Pri porovnaní vojvodstva Arpádovcov s podobnými ustanovizňami ich piastovských a přemyslovských súčasníkov môžeme konštatovat', že územné delenie moci sa nemusí nevyhnutne zhodovat' s kompetenčným. Presný územný rozsah vojvodstva dodnes nepoznáme. Môžeme však s určitost'ou tvrdit', že jeho strediská, 


\section{Dániel Bagi}

na rozdiel napríklad od piastovských, sa len v nepatrnej miere dotýkali hlavných panovníckych sídiel. Kým pretrvávali dobré vzt’ahy v panovníckej rodine, vojvodovia disponovali vážnymi kompetenciami. Tieto kompetencie však znamenali v prvom rade podiel na král'ovskej moci, čiže dohoda znamenala vždy $\mathrm{v}$ prvom rade rozdelenie kompetencií. To možno vysvetl'uje, prečo sa králi a vojvodovia pravidelne spolu objavujú na hlavných miestach krajiny ako aj inde, spoločne reprezentujúc panovnícku moc. Na druhom konci stupnice sú moravské kniežatá. Morava už od polovice 11. storočia disponovala preukázatel'nou oddelenou územnou vládou, moravské kniežatá aj napodobňovali svojich pražských príbuzných, ale skutočným mocenským oprávnením nedisponovali a pravidelne sa búrili proti príbuzenskému „útlaku“.

Model del'by moci Arpádovcov v 11. storočí bol teda v prvom rade rodinný. Jeho základom bol konsenzus medzi členmi rodiny. V zmysle tohto konsenzu sa del'ba moci dotýkala celej krajiny v pomere $2: 1$. Pramene sa nezmieňujú o tom, čo si presne členovia panovníckej rodiny medzi sebou rozdelili. Môžeme sa domnievat', že to bolo preto, lebo to nebolo potrebné, ked'že pod výrazom divisio regni, uhorský kronikár rozumel $v$ prvom rade spory o trón, ako aj rozdelenie moci.

Preklad z mad'arčiny: Sabina Danková 